\title{
Visible-Light-Mediated Iodoperfluoroalkylation of Alkenes in Flow and Its Application to the Synthesis of a Key Fulvestrant Intermediate
}

Cristian Rosso $^{\ddagger, \|}$, Jason D. Williams ${ }^{\ddagger}$, , Giacomo Filippinill, Maurizio Prato $^{\|, \#, \perp}$ and C. Oliver Kappe $^{*, \$}, \S$

\#nstitute of Chemistry, University of Graz, NAWI Graz, Heinrichstrasse 28, 8010 Graz, Austria

${ }^{\S}$ Center for Continuous Flow Synthesis and Processing (CC FLOW), Research Center Pharmaceutical Engineering GmbH (RCPE), Inffeldgasse 13, $8010 \mathrm{Graz}$, Austria

"Department of Chemical and Pharmaceutical Sciences, INSTM UdRTrieste, University of Trieste, Via Licio Giorgieri 1, 34127 Trieste, Italy

\#Nanobiotechnology Laboratory, CIC biomaGUNE, San Sebastiàn, Spain

${ }^{\perp}$ Ikerbasque, Basque Foundation for Science, Bilbao, Spain

*E-mail: oliver.kappe@uni-graz.at 


\section{Contents}

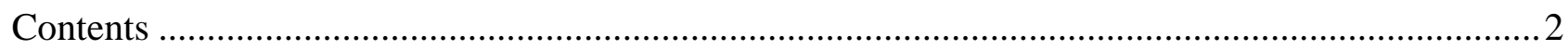

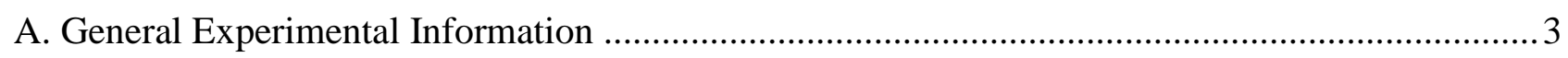

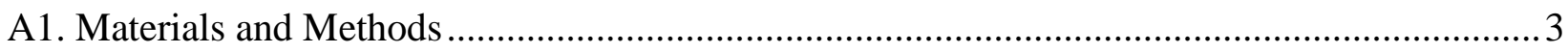

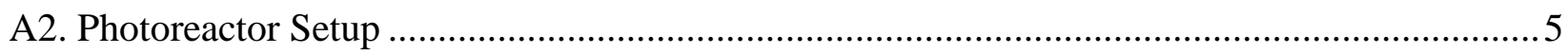

B. Synthesis of $N, N$-bis(2,6-diisopropylphenyl)perylene-3,4,9,10-bis(dicarboximide) (PDI) ...........8

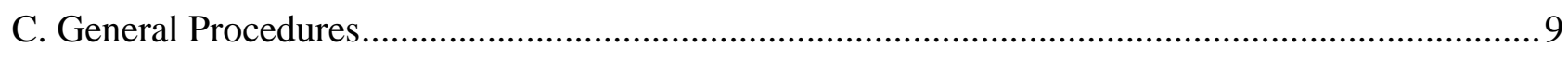

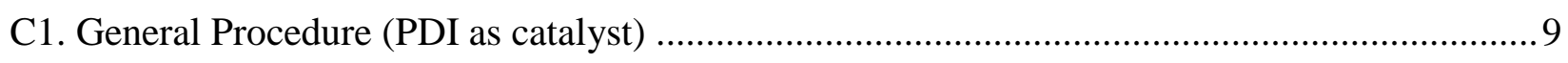

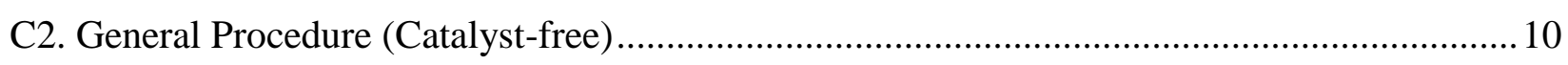

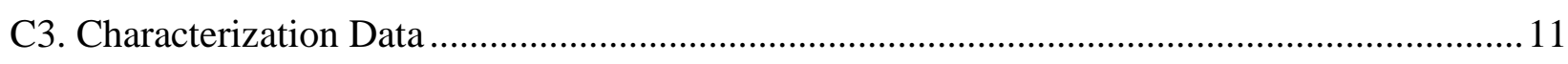

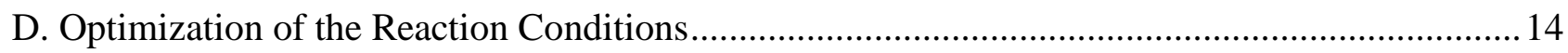

D1. Optimization of the Reaction Conditions at $450 \mathrm{~nm}$ Using PDI as Photocatalyst................ 14

D2. Optimization of the Reaction Conditions at $405 \mathrm{~nm}$ in Absence of PDI ............................ 16

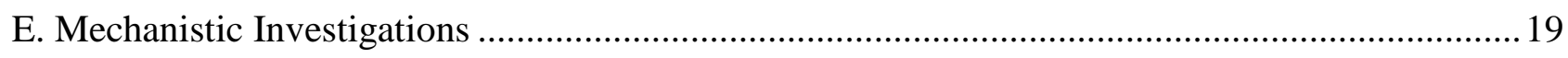

E1. Determination of Binding Stoichiometry and Association Constant by ${ }^{19}$ F-NMR ............... 19

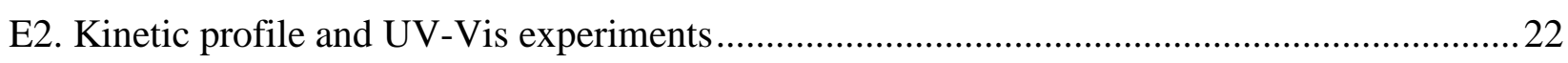

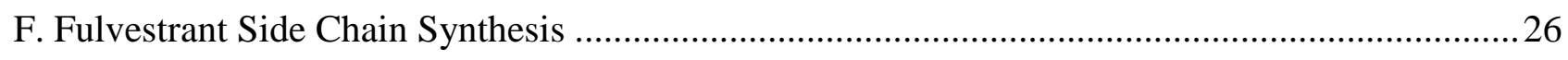

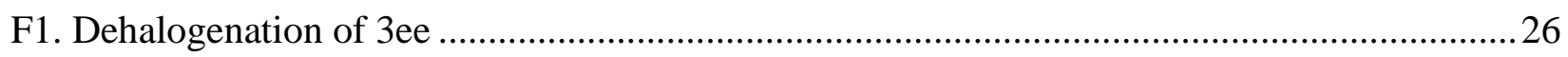

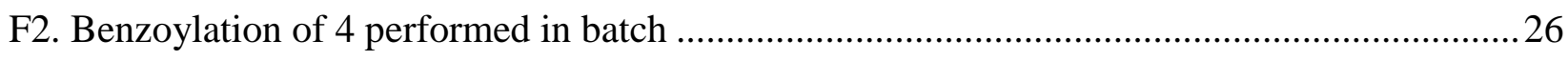

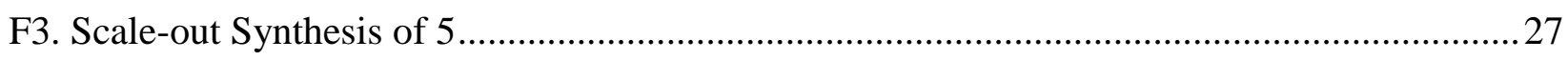

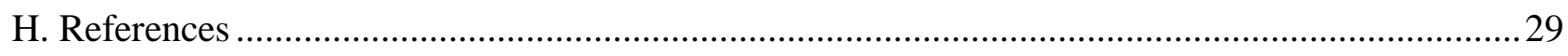

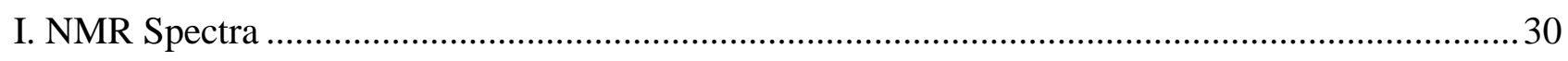




\section{A. General Experimental Information}

\section{A1. Materials and Methods}

Commercial reagents and solvents were purchased (Sigma-Aldrich, Fluka, Alfa Aesar, Fluorochem or VWR) and used as received, without further purification, unless otherwise stated.

1-Octene (1a), cyclohexene (1b), cyclooctene (1c), allylbenzene (1d), allyl alcohol (1e), 1-hexyne (1f), diphenylacetylene (1g), propargyl alcohol (1h), perfluorohexyl iodide (2a), nonafluoro-1-iodobutane (2b), heptafluoro-2-iodopropane (2c), trifluoroiodomethane (2d), pentafluoroiodoethane (2e), triethylamine, pyridine and benzoyl chloride were all commercially available.

Chromatographic purification of products was accomplished using flash chromatography on silica gel (35-70 mesh) or using a Biotage Isolera automated flash chromatography system with cartridges packed with KPSIL, $60 \AA$ (32-63 $\mu \mathrm{m}$ particle size).

For thin layer chromatography (TLC) analysis, Merck pre-coated TLC plates (silica gel 60 GF254, $0.25 \mathrm{~mm}$ ) were employed, using UV light as the visualizing agent $(254 \mathrm{~nm})$, basic aqueous potassium permanganate $\left(\mathrm{KMnO}_{4}\right)$ stain solution or iodine and heat as developing agents.

Organic solutions were concentrated under reduced pressure on a Büchi rotatory evaporator.

NMR spectra were recorded on Bruker $300 \mathrm{MHz}$ spectrometer $\left({ }^{1} \mathrm{H}: 300 \mathrm{MHz},{ }^{13} \mathrm{C}: 75 \mathrm{MHz}\right.$ and $282 \mathrm{MHz}$ for ${ }^{19} \mathrm{~F}$ ). The chemical shifts $(\delta)$ for ${ }^{1} \mathrm{H},{ }^{13} \mathrm{C}$ and ${ }^{19} \mathrm{~F}$ are given in ppm relative to residual signals of the solvent $\left(\mathrm{CHCl}_{3}\right.$ at $7.26 \mathrm{ppm}{ }^{1} \mathrm{H}-\mathrm{NMR}$ and $\left.77.16 \mathrm{ppm}{ }^{13} \mathrm{C}-\mathrm{NMR}\right)$. Coupling constants are given in Hertz (Hz). The following abbreviations are used to indicate the multiplicity: s, singlet; d, doublet; t, triplet; q, quartet; dd, doublet of doublets; ddd, doublet of doublet of doublets; m, multiplet.

GC-FID analyses were performed on a ThermoFisher Focus GC with a flame ionization detector, using a TR-5MS column $(30 \mathrm{~m} \times 0.25 \mathrm{~mm}$ ID $\times 0.25 \mu \mathrm{m})$ and helium as carrier gas $(1 \mathrm{~mL} / \mathrm{min}$ constant flow). The injector temperature was set to $280{ }^{\circ} \mathrm{C}$. After $1 \mathrm{~min}$ at $50{ }^{\circ} \mathrm{C}$, the temperature was increased by $25{ }^{\circ} \mathrm{C} / \mathrm{min}$ to $300{ }^{\circ} \mathrm{C}$ and kept constant at $300{ }^{\circ} \mathrm{C}$ for $4 \mathrm{~min}$. The detector gases used for flame ionization were hydrogen and synthetic air (5.0 quality).

High resolution mass spectrometry (HRMS) measurements were performed using a Q-Exactive Hybrid Quadrupole-Orbitrap MS following flow injection analysis of the re-dissolved sample with a Dionex Ultimate 3000 series HPLC-system (Thermo Fisher Sci., Erlangen, Germany). The injection volume was $5 \mu \mathrm{L}$ and the flow was $200 \mu \mathrm{L} / \mathrm{min}$ of acetonitrile (>99.9 \% HPLC-grade; Chem-Lab NV, Zedelgem, Germany). The HR-MS was fitted with, either a HESI-II atmospheric pressure electrospray ionization source, or a combination of an APCI Ion Max heated probe source with an APPI Photo Mate ${ }^{\circledR}$ UV light 
source for mixed atmospheric pressure chemical and photo ionization. Nitrogen was used as nebulizer and drying gas.

ESI measurements were performed in negative ionization mode using the following settings: spray voltage $2.5 \mathrm{kV}$, capillary temperature $250{ }^{\circ} \mathrm{C}$, sheath gas flow rate 45 instrument units (IU), auxiliary gas temperature $300{ }^{\circ} \mathrm{C}$, auxiliary gas flow rate $10 \mathrm{IU}$, automatic gain control target $3 \mathrm{e}^{6}$, maximum injection time $100 \mathrm{~ms}$, and the resolution was 70000 (FWHM).

APCI+APPI measurements were performed in positive ionization mode using the following settings: corona discharge current $+4 \mu \mathrm{A}$, sheath gas flow rate $20 \mathrm{IU}$, auxiliary gas flow rate $5 \mathrm{IU}$, and the remaining settings were the same as for ESI. High resolution mass spectra were extracted from a scanned mass range of $\mathrm{m} / \mathrm{z}$ 220-390 in both ionization modes.

Infrared spectra were measured on a Bruker alpha p instrument, using attenuated total reflectance (ATR). Spectra were processed using OPUS v6.5 software.

UV-Vis spectra were recorded using a fiber-coupled Avantes Starline AvaSpec-2048 spectrometer, with an Avantes AvaLight-DHc lamp as the light source. These spectra were processed using Avasoft 8.7 software.

Dehalogenation reactions using $\mathrm{PtO}_{2}$ catalyst (commercially available $70 \mathrm{~mm}$ CatCart ${ }^{\circledR}$, supplied by Thales Nano) under continuous flow were performed using an H-CUBE Pro® system from ThalesNano, with a Knauer HPLC pump. 


\section{A2. Photoreactor Setup}

All photochemical reactions were conducted in a commercial continuous-flow reactor: Corning AdvancedFlow Lab Photo Reactor (Figure S1).

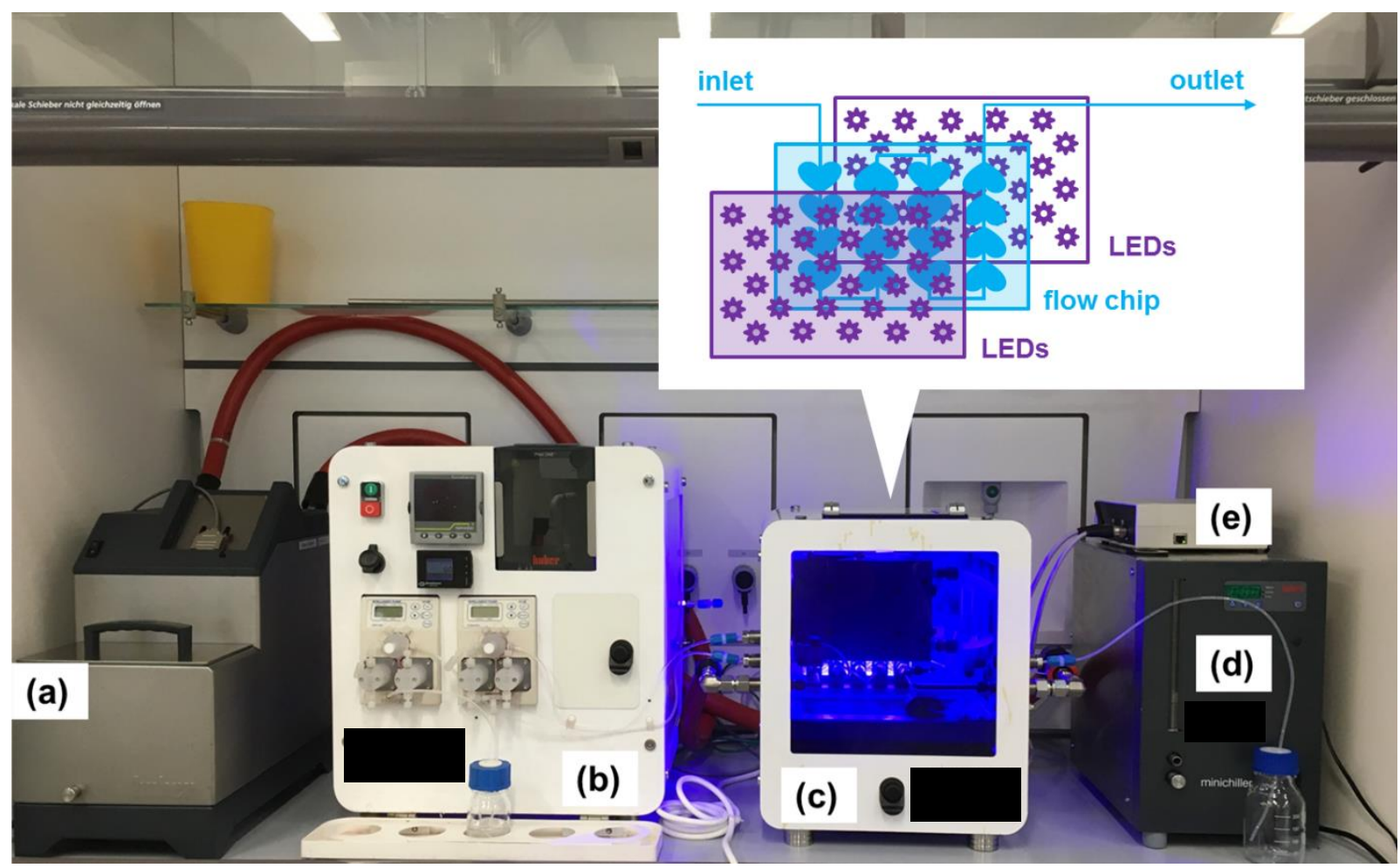

Figure S1. Photograph of commercial photoreactor setup: a) temperature control for reaction plate; b) control module, containing pumps, mass flow controller, Huber controller and data logger; c) fluidic module housing, with tinted plastic panels for light containment; d) temperature control for LED panels; e) wireless receiver for LED control.

Reactor module (G1 "low flow" fluidic module): A compact glass fluidic module $(155 \times 125 \times 8 \mathrm{~mm}$ size, $0.3 \mathrm{~mm}$ channel depth, $2.77 \mathrm{~mL}$ internal volume), encased within a high capacity heat exchange channel (20 $\mathrm{mL}$ volume).

Light source: LED panels were mounted on both sides of the fluidic module (40 $\mathrm{mm}$ from the center of the reaction layer). Each LED panel was equipped with 20 LEDs of 6 different wavelengths (120 LEDs in total) and a heat exchanger $\left(\mathrm{T}=15^{\circ} \mathrm{C}\right)$. The LED wavelength and intensity was controlled externally using a webbased interface, connected wirelessly to a router.

Two separate panels were used for various experiments in this study (panel $1=365,385,405,485,610 \mathrm{~nm}$ and "4000K" white light; panel $2=340,375,395,422,450,540 \mathrm{~nm}$; see emission spectra below, Figure S2 and Figure S3). 
Table S1. Power and photon flux of all LEDs used in this study.

\begin{tabular}{|c|c|c|c|}
\hline Wavelength (nm) & $\begin{array}{l}\text { Single LED Luminous } \\
\text { Flux }(\mathbf{W})^{[a]}\end{array}$ & $\begin{array}{c}\text { Entire Array Luminous } \\
\qquad \operatorname{Flux}(\mathbf{W})^{[b]}\end{array}$ & $\begin{array}{c}\text { Entire Array Photon } \\
\text { Flux }\left(\mathbf{m m o l ~ h}^{-1}\right)^{[\mathrm{c}]}\end{array}$ \\
\hline 340 & 0.0725 & 2.9 & 30 \\
\hline 365 & 1.09 & 43.6 & 477 \\
\hline 375 & 1.16 & 46.4 & 522 \\
\hline 385 & 1.34 & 53.6 & 619 \\
\hline 395 & 1.34 & 53.6 & 635 \\
\hline 405 & 1.42 & 56.8 & 690 \\
\hline 422 & 0.91 & 36.4 & 461 \\
\hline 450 & 1.19 & 47.6 & 650 \\
\hline 485 & $n \cdot a^{[\mathrm{d}]}$ & $n . a .^{[\mathrm{d}]}$ & $n . a .^{[\mathrm{d}]}$ \\
\hline 540 & 0.47 & 18.8 & 299 \\
\hline 610 & $n . a .^{[\mathrm{d}]}$ & $n . a .^{[\mathrm{d}]}$ & $n . a .^{[\mathrm{d}]}$ \\
\hline $4000 \mathrm{~K}$ & 1.52 & 60.8 & $n . a .^{[\mathrm{d}]}$ \\
\hline
\end{tabular}

${ }^{[a]}$ LED luminous flux data taken from its corresponding data sheet (output power). [b]"'Entire array" consists of 40 individual LEDs. ${ }^{[\mathrm{cc}}$ Photon flux for the entire array, calculated by:

$$
\text { moles per hour }=\lambda(n m) \times \text { power }(W) \times 3 \times 10^{-5}
$$

as previously described in the literature. ${ }^{\mathrm{S} 1 \mathrm{~d}]} n . a$. denotes that this LED power value is not available.

\section{LED Panel 1}

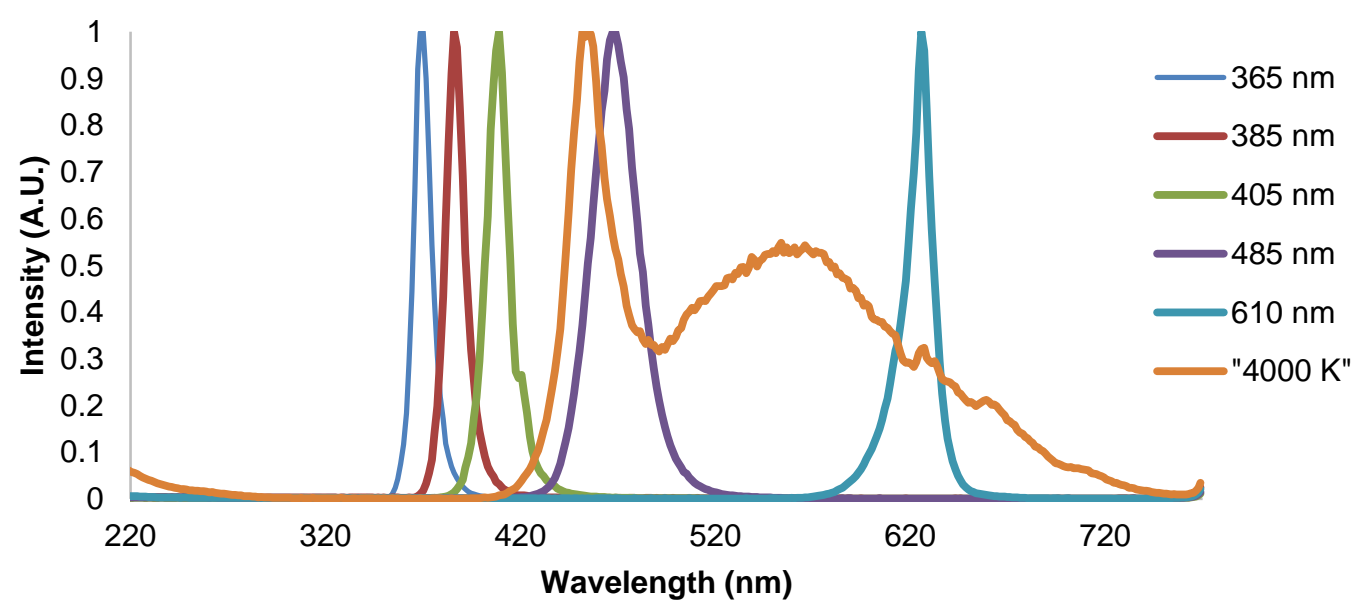

Figure S2. Emission spectra of LEDs on "Panel 1" used in this study. Note: this graph gives no impression of light intensity, since emission intensities are normalized. 


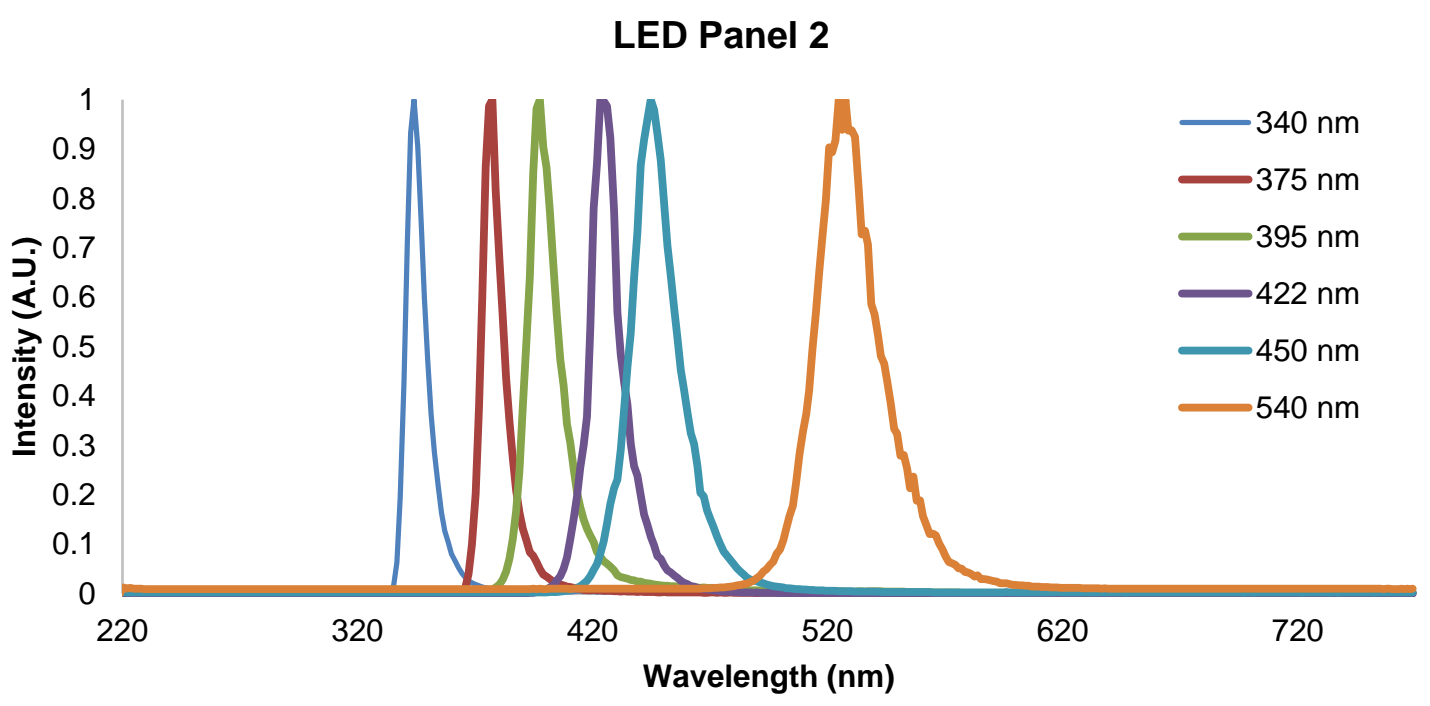

Figure S3. Emission spectra of LEDs on "Panel 2" used in this study. Note: this graph gives no impression of light intensity, since emission intensities are normalized.

Temperature control: Thermal regulation of the LED panels was carried out using a Huber Minichiller 280 filled with $30 \%$ ethylene glycol in water. Thermal regulation of the glass fluidic module was carried out using a Huber Ministat 230 filled with silicon oil $\left(-20^{\circ} \mathrm{C}\right.$ to $\left.195^{\circ} \mathrm{C}\right)$.

Pumps: The feed solution was conveyed to the photoreactor using a FLOM UI 22-110DC HPLC pump (0.01-10 $\mathrm{mL} / \mathrm{min}$; wetted-parts: PTFE, PCTFE, FFKM and ruby).

Back pressure regulator: For experiments using gaseous perfluoroalkyl iodides, a dome-type back pressure regulator (BPR-10, Zaiput Flow Technologies) was installed after the reactor exit with a set point of 3 bar.

General connections: Connection between the pumps, fluidic module input and output was achieved using 1/8" (external diameter) PFA tubing (Swagelok), using metal-free connectors (Swagelok MS-GC-2 swaging system). Other connections used 1/16" (external diameter) PFA tubing, with PEEK fittings.

Sample loop: For optimization and substrate scope experiments, an Upchurch 6-way switching valve was used (part \# V-450, https://www.idex-hs.com/store/injection-valve-2-postion-6-port-040-black.html), with a $5 \mathrm{~mL}$ sample loop (made from 1/16" outer diameter, $0.8 \mathrm{~mm}$ internal diameter PFA tubing) installed. 


\section{B. Synthesis of $N, N$-bis(2,6-diisopropylphenyl)perylene-3,4,9,10- bis(dicarboximide) (PDI)}

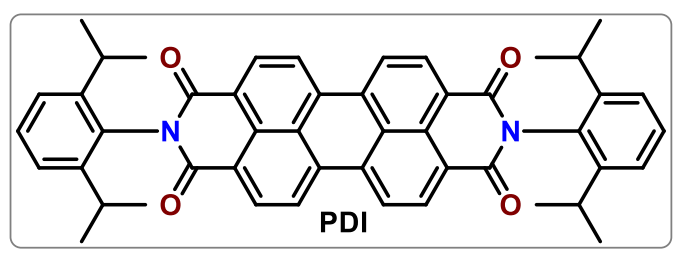

PDI was prepared according to the literature procedure:

A mixture of 2,6-diisopropylaniline $(2.07 \mathrm{~mL}, 11 \mathrm{mmol})$, perylene-3,4:9,10-tetracarboxylic dianhydride $(1.96 \mathrm{~g}, 5 \mathrm{mmol})$ and imidazole $(10 \mathrm{~g})$ was stirred at $140{ }^{\circ} \mathrm{C}$ for $4 \mathrm{~h}$, then diluted with ethanol. This was followed by the addition of $\mathrm{HCl}(2 \mathrm{M}, 200 \mathrm{~mL})$. The reaction mixture was then allowed to settle. The precipitate thus formed was collected through vacuum filtration. Further purification by silica gel chromatography using dichloromethane as the eluent provided the desired product (PDI) in $75 \%$ yield $(2.70 \mathrm{~g})$. The characterization of the compound matches the data reported in the literature. ${ }^{\mathrm{S} 2}$ 


\section{General Procedures}

\section{C1. General Procedure (PDI as catalyst)}

Iodoperfluoroalkylation of Alkenes at $450 \mathrm{~nm}$ with PDI photocatalyst

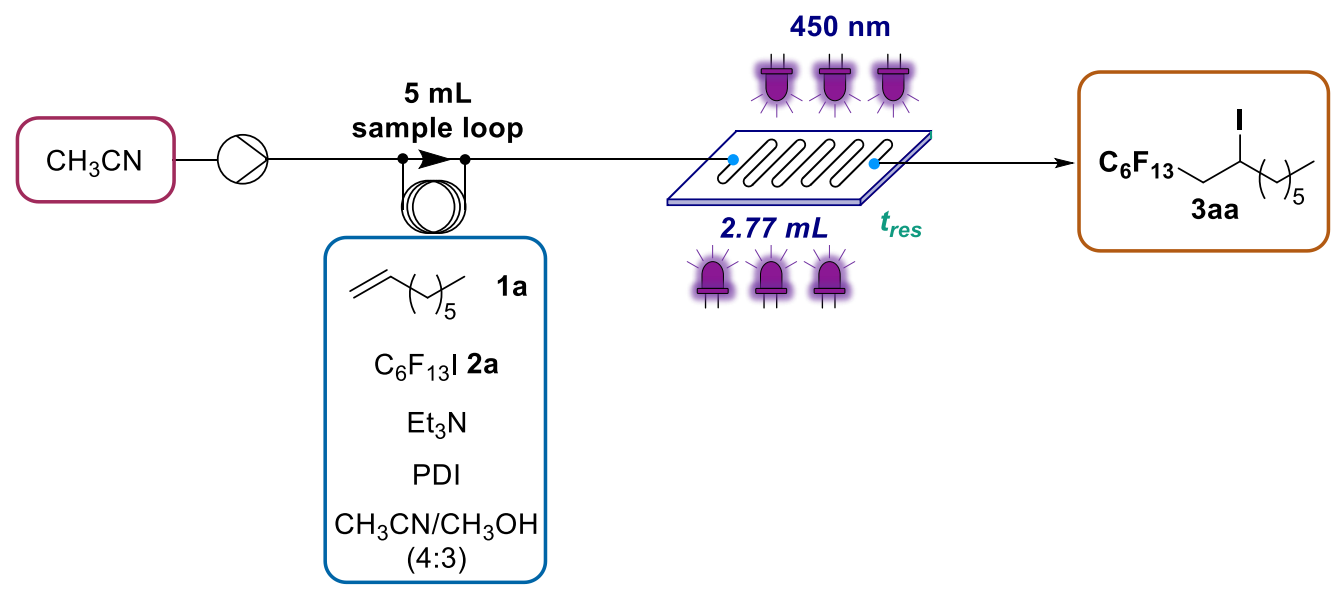

Scheme S1. Flow diagram showing general reaction setup for $450 \mathrm{~nm}$ experiments using PDI as photocatalyst.

The 40 LED array was switched on at $450 \mathrm{~nm}$ and its thermal fluid was set to $15^{\circ} \mathrm{C}$. The reaction plate thermostat was set to $20{ }^{\circ} \mathrm{C}$. A solution of 1 -octene $1 \mathbf{a}(1 \mathrm{mmol}, 1$ equiv) perfluorohexyl iodide $\mathbf{2 a}$ (1.2 mmol, 1.2 equiv), PDI $(0.05 \mathrm{~mol} \%=500 \mathrm{ppm}$, with respect to alkene $1 \mathrm{a}, 0.35 \mathrm{mg})$ and triethylamine ( $0.2 \mathrm{mmol}, 0.2$ equiv) was made up in degassed acetonitrile/methanol in 4:3 ratio (5 mL total volume in a volumetric flask, solvent was degassed prior to use by sparging with argon for 15 minutes, $[1 \mathbf{a}]_{0}=0.2 \mathrm{M}$ ), then loaded into a $5 \mathrm{~mL}$ injection loop (fitted to an Upchurch 6-way valve). Acetonitrile was pumped through the $2.77 \mathrm{~mL}$ reaction plate at $0.554 \mathrm{~mL} / \mathrm{min}$ flow rate, corresponding to $5 \mathrm{~min}$ residence time. After allowing the reactor to equilibrate for roughly $15 \mathrm{~min}$, the reaction mixture was injected from the sample loop. The central $1 \mathrm{~mL}$ portion of this sample was collected for analysis by gas chromatography (GCFID). For the isolation run, additional volume was collected to ensure that none of the $5 \mathrm{~mL}$ reaction mixture was lost due to longitudinal diffusion. The solvent was removed under reduced pressure and the residue was purified by column chromatography (eluent: petroleum ether/ethyl acetate) to give the corresponding iodoperfluoroalkyl compound 3aa.

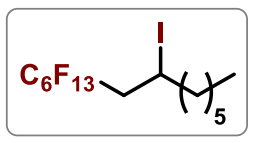

1,1,1,2,2,3,3,4,4,5,5,6,6-tridecafluoro-8-iodotetradecane (3aa). Prepared according to the general procedure $\mathbf{C 1}$ using 1-octene $\mathbf{1 a}(1 \mathrm{mmol}, 157 \mu \mathrm{L})$ and perfluorohexyl iodide 2a $(1.2 \mathrm{mmol}, 260 \mu \mathrm{L})$. The product 3aa was obtained as colorless oil (503 $\mathrm{mg}, 90 \%$ yield). The characterization of the compound matches the data reported in the literature. ${ }^{\mathrm{S} 3}$ 


\section{C2. General Procedure (Catalyst-free)}

\section{Iodoperfluoroalkylation of Alkenes at $405 \mathrm{~nm}$ in the absence of PDI}

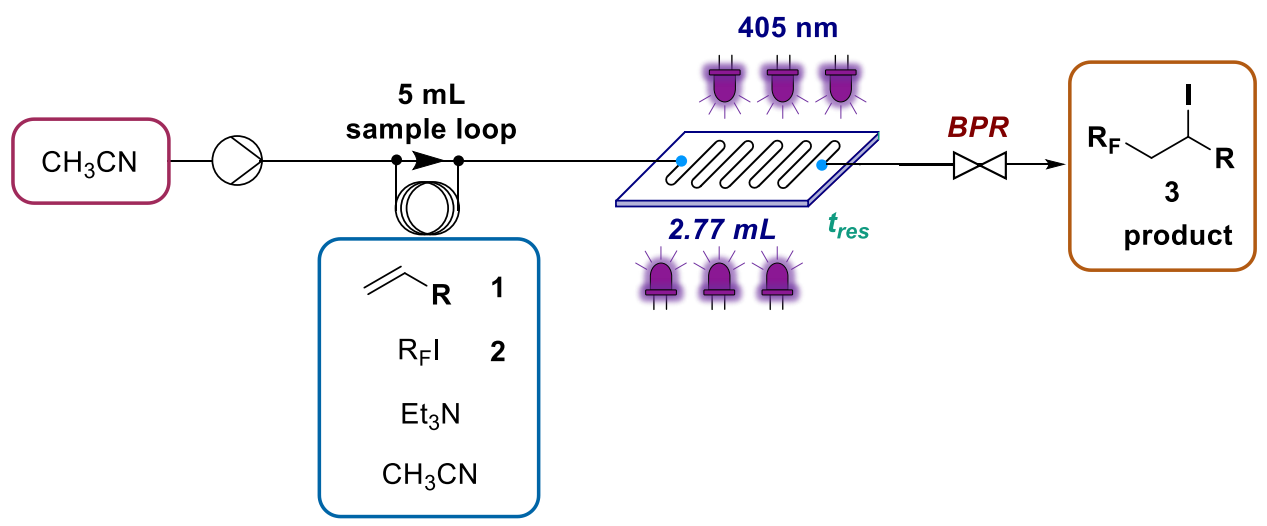

Scheme S2. Flow diagram showing general reaction setup for $405 \mathrm{~nm}$ experiments.

The 40 LED array was switched on at $405 \mathrm{~nm}$ and its thermal fluid was set to $15{ }^{\circ} \mathrm{C}$. The reaction plate thermostat was set to $20^{\circ} \mathrm{C}$. A solution of alkene $\mathbf{1}$ (1.25 mmol, 1 equiv) perfluoroalkyl iodide $\mathbf{2}$ (1.5 mmol, 1.2 equiv, for $\mathbf{2 d}$ and $2 \mathrm{e}: 5 \mathrm{mmol}, 4$ equiv from a $2 \mathrm{M}$ solution in acetonitrile), and triethylamine $(0.25 \mathrm{mmol}$, 0.2 equiv) was made up in degassed acetonitrile $(5 \mathrm{~mL}$ total volume in a volumetric flask, solvent was degassed prior to use by sparging with argon for 15 minutes, $[\mathbf{1}]_{0}=0.25 \mathrm{M}$ ), then loaded into a $5 \mathrm{~mL}$ injection loop (fitted to an Upchurch 6-way valve). Using a Zaiput back pressure regulator, a pressure of 3 bar was set before using perfluoroalkyl iodides $\mathbf{2 d}$ and 2e. Acetonitrile was pumped through the $2.77 \mathrm{~mL}$ reaction plate at 0.554 to $0.139 \mathrm{~mL} / \mathrm{min}$ flow rate, corresponding to 5,10 or $20 \mathrm{~min}$ residence time. After allowing the reactor to equilibrate for roughly $15 \mathrm{~min}$, the reaction mixture was injected from the sample loop. The central $1 \mathrm{~mL}$ portion of this sample was collected for analysis by gas chromatography (GC-FID). For the isolation run, additional volume was collected to ensure that none of the $5 \mathrm{~mL}$ reaction mixture was lost due to longitudinal diffusion. The solvent was removed under reduced pressure and the residue was purified by column chromatography (eluent: petroleum ether/ethyl acetate) to give the corresponding iodoperfluoroalkyl compound $\mathbf{3}$. 


\section{C3. Characterization Data}

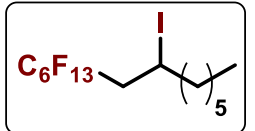

1,1,1,2,2,3,3,4,4,5,5,6,6-tridecafluoro-8-iodotetradecane (3aa). Prepared according to the general procedure C2 using 1-octene 1a (1.25 mmol, $196 \mu \mathrm{L})$ and perfluorohexyl iodide $2 \mathbf{a}(1.5 \mathrm{mmol}, 325 \mu \mathrm{L})$ in a residence time of $5 \mathrm{~min}$. The product 3aa was obtained as colorless oil (660 mg, 95\% yield). The characterization of the compound matches the data reported in the literature. ${ }^{\mathrm{S} 3}$

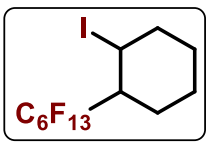

1-iodo-2-(perfluorohexyl)cyclohexane (3ba). Prepared according to the general procedure C2 using cyclohexene $\mathbf{1 b}(1.25 \mathrm{mmol}, 127 \mu \mathrm{L})$ and perfluorohexyl iodide $\mathbf{2 a}(1.5 \mathrm{mmol}, 325$ $\mu \mathrm{L}$ ) in a residence time of $10 \mathrm{~min}$. The product $\mathbf{3 b a}$ was obtained as colorless oil (340 $\mathrm{mg}$, $52 \%$ yield $d . r .=3: 1$ ). The characterization of the compound matches the data reported in the literature. ${ }^{\mathrm{S} 4}$

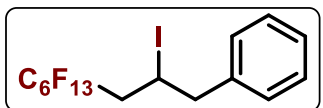

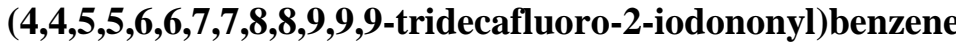

(3da). Prepared according to the general procedure $\mathbf{C 2}$ using allylbenzene $\mathbf{1 d}(1.25 \mathrm{mmol}, 166 \mu \mathrm{L})$ and perfluorohexyl iodide 2a $(1.5 \mathrm{mmol}, 325 \mu \mathrm{L})$ in a residence time of $10 \mathrm{~min}$. The product 3da was obtained as colorless oil (618 $\mathrm{mg}, 88 \%$ yield). The characterization of the compound matches the data reported in the literature. ${ }^{\mathrm{S} 5}$

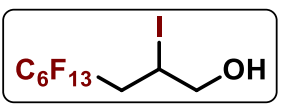

4,4,5,5,6,6,7,7,8,8,9,9,9-tridecafluoro-2-iodononan-1-ol (3ea). Prepared according to the general procedure $\mathbf{C 2}$ using allyl alcohol $1 \mathbf{e}(1.25 \mathrm{mmol}, 85 \mu \mathrm{L})$ and perfluorohexyl iodide $2 \mathbf{a}(1.5 \mathrm{mmol}, 325 \mu \mathrm{L})$ in a residence time of $5 \mathrm{~min}$. The product 3ea was obtained as white solid (573 $\mathrm{mg}, 91 \%$ yield). The characterization of the compound matches the data reported in the literature. ${ }^{\mathrm{S} 6}$

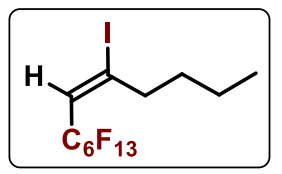

(E)-7,7,8,8,9,9,10,10,11,11,12,12,12-tridecafluoro-5-iodododec-5-ene (3fa). Prepared according to the general procedure $\mathbf{C 2}$ using 1-hexyne 1f $(1.25 \mathrm{mmol}, 144 \mu \mathrm{L})$ and perfluorohexyl iodide $2 \mathrm{a}(1.5 \mathrm{mmol}, 325 \mu \mathrm{L})$ in a residence time of $5 \mathrm{~min}$. The product 3fa was obtained as colorless oil $(465 \mathrm{mg}, 70 \%$ yield, $E / Z$ ratio $=5.7: 1)$. The characterization of the compound matches the data reported in the literature. ${ }^{\mathrm{S} 7}$

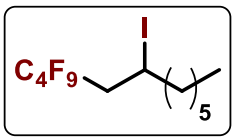

1,1,1,2,2,3,3,4,4-nonafluoro-6-iodododecane (3ab). Prepared according to the general procedure $\mathbf{C 2}$ using 1-octene $\mathbf{1 a}(1.25 \mathrm{mmol}, 196 \mu \mathrm{L})$ and nonafluoro-1-iodobutane $\mathbf{2 b}$ (1.5 mmol, $258 \mu \mathrm{L}$ ) in a residence time of $5 \mathrm{~min}$. The product 3ab was obtained as colorless oil (499 mg, 87\% yield). The characterization of the compound matches the data reported in the literature. ${ }^{\mathrm{S} 8}$

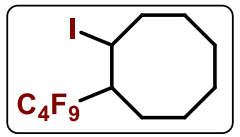

1-iodo-2-(perfluorobutyl)cyclooctane (3cb). Prepared according to the general procedure C2 using cyclooctene 1c $(1.25 \mathrm{mmol}, 162 \mu \mathrm{L})$ and nonafluoro-1-iodobutane $\mathbf{2 b}$ (1.5 mmol, $258 \mu \mathrm{L}$ ) in a residence time of $10 \mathrm{~min}$. The product $\mathbf{3 c b}$ was obtained as colorless oil (417 
mg, $73 \%$ yield, d.r. $=1.9: 1)$. The characterization of the compound matches the data reported in the literature. $^{\mathrm{S} 9}$

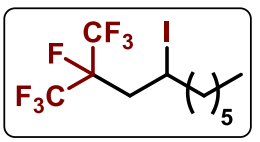

1,1,1,2-tetrafluoro-4-iodo-2-(trifluoromethyl)decane (3ac). Prepared according to the general procedure C2 using 1-octene 1a $(1.25 \mathrm{mmol}, 196 \mu \mathrm{L})$ and heptafluoro-2iodopropane $\mathbf{2 c}(1.5 \mathrm{mmol}, 213 \mu \mathrm{L})$ in a residence time of $10 \mathrm{~min}$. The product 3ac was obtained as colorless oil (378 $\mathrm{mg}, 74 \%$ yield). The characterization of the compound matches the data reported in the literature. ${ }^{\text {S10 }}$

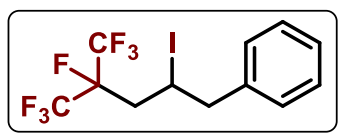

(4,5,5,5-tetrafluoro-2-iodo-4-(trifluoromethyl)pentyl)benzene (3dc). Prepared according to the general procedure $\mathbf{C 2}$ using allylbenzene $\mathbf{1 d}(1.25 \mathrm{mmol}, 166 \mu \mathrm{L})$ and heptafluoro-2-iodopropane $2 \mathrm{c}(1.5 \mathrm{mmol}, 213 \mu \mathrm{L})$ in a residence time of 10 min. The product 3dc was obtained as colorless oil (405 $\mathrm{mg}, 78 \%$ yield). The characterization of the compound matches the data reported in the literature. ${ }^{\mathrm{S} 11}$

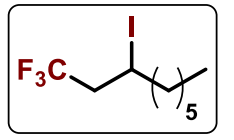

1,1,1-trifluoro-3-iodononane (3ad). Prepared according to the general procedure $\mathbf{C 2}$ using 1-octene $1 \mathbf{a}(1.25 \mathrm{mmol}, 196 \mu \mathrm{L})$ and trifluoroiodomethane $\mathbf{2 d}(5 \mathrm{mmol}, 2.5 \mathrm{~mL}$ of a $2 \mathrm{M}$ solution in acetonitrile) in a residence time of $10 \mathrm{~min}$. The product 3ad was obtained as colorless oil (348 mg, 90\% yield). The characterization of the compound matches the data reported in the literature. $^{\mathrm{S} 12}$

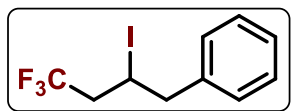

(4,4,4-trifluoro-2-iodobutyl)benzene (3dd). Prepared according to the general procedure $\mathbf{C 2}$ using allylbenzene $\mathbf{1 d}(1.25 \mathrm{mmol}, 166 \mu \mathrm{L})$ and trifluoroiodomethane $\mathbf{2 d}$ ( $5 \mathrm{mmol}, 2.5 \mathrm{~mL}$ of a $2 \mathrm{M}$ solution in acetonitrile) in a residence time of $20 \mathrm{~min}$. The product $3 \mathrm{dd}$ was obtained as colorless oil ( $327 \mathrm{mg}, 83 \%$ yield). The characterization of the compound matches the data reported in the literature. ${ }^{\mathrm{S} 13}$

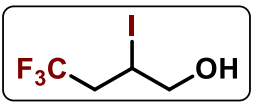

4,4,4-trifluoro-2-iodobutan-1-ol (3ed). Prepared according to the general procedure $\mathbf{C 2}$ using allyl alcohol 1e $(1.25 \mathrm{mmol}, 85 \mu \mathrm{L})$ and trifluoroiodomethane $2 \mathbf{d}(5 \mathrm{mmol}, 2.5 \mathrm{~mL}$ of a $2 \mathrm{M}$ solution in acetonitrile) in a residence time of $20 \mathrm{~min}$. The product 3ed was obtained as colorless oil (255 mg, 80\% yield). ${ }^{1} \mathrm{H}-\mathrm{NMR}\left(300 \mathrm{MHz}, \mathrm{CDCl}_{3}\right) \delta 4.33-4.22(\mathrm{~m}, 1 \mathrm{H}), 3.77(\mathrm{t}, J=4.9 \mathrm{~Hz}, 2 \mathrm{H}), 3.10-2.64$ (m, 2H), 2.49 (s, 1H); ${ }^{13} \mathrm{C}-\mathrm{NMR}\left(75 \mathrm{MHz}, \mathrm{CDCl}_{3}\right) \delta 125.62$ (q, $\left.J=278.1 \mathrm{~Hz}\right), 67.59$ (d, $\left.J=0.7 \mathrm{~Hz}\right), 40.75$ $(\mathrm{q}, J=29.1 \mathrm{~Hz}), 22.75(\mathrm{q}, J=2.6 \mathrm{~Hz}) ;{ }^{19} \mathrm{~F}-\mathrm{NMR}\left(282 \mathrm{MHz}, \mathrm{CDCl}_{3}\right) \delta-64.26(\mathrm{t}, J=10.3 \mathrm{~Hz}, 3 \mathrm{~F})$; IR (ATR, neat, $\mathrm{cm}^{-1}$ ): 3371, 1250, 1136, 1111, 1069, 1040, 1006; HRMS (ESI, negative mode) calculated for $\mathrm{C}_{4} \mathrm{H}_{5} \mathrm{OF}_{3} \mathrm{I}[\mathrm{M}-\mathrm{H}]:: 252.9337$, found: 252.9344 . 


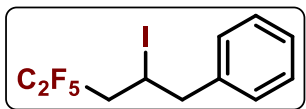

(4,4,5,5,5-pentafluoro-2-iodopentyl)benzene (3de). Prepared according to the general procedure C2 using allylbenzene 1d $(1.25 \mathrm{mmol}, 166 \mu \mathrm{L})$ and pentafluoroiodoethane $2 \mathrm{e}$ ( $5 \mathrm{mmol}, 2.5 \mathrm{~mL}$ of a $2 \mathrm{M}$ solution in acetonitrile) in a residence time of $20 \mathrm{~min}$. The product 3de was obtained as colorless oil (394 mg, 87\% yield). ${ }^{1} \mathrm{H}-\mathrm{NMR}\left(300 \mathrm{MHz}, \mathrm{CDCl}_{3}\right) \delta 7.41-$ $7.29(\mathrm{~m}, 3 \mathrm{H}), 7.25-7.18(\mathrm{~m}, 2 \mathrm{H}), 4.47$ (ddd, $J=12.8,8.8,6.4 \mathrm{~Hz}, 1 \mathrm{H}), 3.26$ (ddd, $J=23.4,14.6,7.3 \mathrm{~Hz}$, 2H), 3.02-2.71 (m, 2H).); ${ }^{13} \mathrm{C}-\mathrm{NMR}\left(75 \mathrm{MHz}, \mathrm{CDCl}_{3}\right) \delta 138.70$ (s), 129.09 (s), 128.78 (s), 127.48 (s), 47.06 $(\mathrm{d}, J=1.6 \mathrm{~Hz}), 40.77(\mathrm{t}, J=20.8 \mathrm{~Hz}), 19.54(\mathrm{~s}) ;{ }^{19} \mathrm{~F}-\mathrm{NMR}\left(282 \mathrm{MHz}, \mathrm{CDCl}_{3}\right) \delta-85.79$ (s, 3F), -115.88 (ddd, $J=265.0,24.7,12.2 \mathrm{~Hz}, 1 \mathrm{~F}),-117.91(\mathrm{ddd}, J=265.1,22.7,11.7 \mathrm{~Hz}, 1 \mathrm{~F}) ; \mathrm{IR}$ (ATR, neat, $\mathrm{cm}^{-1}$ ): 1318, 1188, 1115, 1009, 743, 697, 508; HRMS (APCI+APPI, positive mode) calculated for $\mathrm{C}_{11} \mathrm{H}_{10} \mathrm{~F}_{5} \mathrm{I}[\mathrm{M}]^{+}: 363.9747$, found: 363.9732; HRMS (APCI+APPI, positive mode) calculated for $\mathrm{C}_{11} \mathrm{H}_{10} \mathrm{~F}_{5}$ [M-I] $]^{+}: 237.0703$, found: 237.0694 .

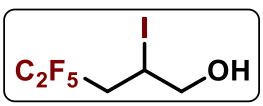

4,4,5,5,5-pentafluoro-2-iodopentan-1-ol (3ee). Prepared according to the general procedure $\mathbf{C 2}$ using allyl alcohol $\mathbf{1 e}(1.25 \mathrm{mmol}, 85 \mu \mathrm{L})$ and pentafluoroiodoethane $\mathbf{2 e}$ ( $5 \mathrm{mmol}, 2.5 \mathrm{~mL}$ of a $2 \mathrm{M}$ solution in acetonitrile) in a residence time of $20 \mathrm{~min}$. The product 3ee was obtained as pale yellow oil (330 mg, 87\% yield). ${ }^{1} \mathrm{H}-\mathrm{NMR}\left(300 \mathrm{MHz}, \mathrm{CDCl}_{3}\right) \delta 4.47-4.32(\mathrm{~m}, 1 \mathrm{H}), 3.80(\mathrm{~s}$, 2H), 3.09-2.56 (m, 2H), $2.44(\mathrm{~s}, 1 \mathrm{H}) ;{ }^{13} \mathrm{C}-\mathrm{NMR}\left(75 \mathrm{MHz}, \mathrm{CDCl}_{3}\right) \delta 67.96(\mathrm{~d}, J=2.1 \mathrm{~Hz}), 37.36(\mathrm{t}, J=21.0$ $\mathrm{Hz}), 21.64(\mathrm{~s}) ;{ }^{19} \mathrm{~F}-\mathrm{NMR}\left(282 \mathrm{MHz}, \mathrm{CDCl}_{3}\right) \delta-85.90(\mathrm{~s}, 3 \mathrm{~F}),-116.73(\mathrm{ddd}, J=264.9,28.4,9.1 \mathrm{~Hz}, 1 \mathrm{~F}),-$ 118.47 (ddd, $J=264.9,26.1,8.9 \mathrm{~Hz}, 1 \mathrm{~F}$ ); IR (ATR, neat, $\mathrm{cm}^{-1}$ ): 3410, 2924, 2853, 1193, 1029, 722; HRMS (ESI, negative mode) calculated for $\mathrm{C}_{5} \mathrm{H}_{5} \mathrm{OF}_{5} \mathrm{I}[\mathrm{M}-\mathrm{H}]^{-}: 302.9305$, found: 302.9314 .

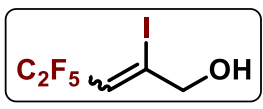

4,4,5,5,5-pentafluoro-2-iodopent-2-en-1-ol (3ie). Prepared according to the general procedure $\mathbf{C} 2$ using propargyl alcohol $\mathbf{1 i}(1.25 \mathrm{mmol}, 73 \mu \mathrm{L})$ and pentafluoroiodoethane $2 \mathrm{e}(5 \mathrm{mmol}, 2.5 \mathrm{~mL}$ of a $2 \mathrm{M}$ solution in acetonitrile) in a residence time of $20 \mathrm{~min}$. The product 3ie was obtained as pale yellow oil $(287 \mathrm{mg}, 76 \%$ yield, E/Z ratio $=1: 1)$. The characterization of the compound matches the data reported in the literature. ${ }^{\text {S14 }}$ 


\section{Optimization of the Reaction Conditions}

\section{D1. Optimization of the Reaction Conditions at $450 \mathrm{~nm}$ Using PDI as Photocatalyst}

A series of optimization studies were performed using 1-octene (1a) and perfluorohexyl iodide (2a) as model reagents in order to explore the reaction parameters. These experiments were carried out following General Procedure C1. Conversions and yields were determinate by calibrated GC-FID analysis using $n$-dodecane as the internal standard.

$$
[3 a a]=\left(\frac{\operatorname{Area}(3 a a)}{\operatorname{Area}(I S)}-c\right) \times \frac{[I S]}{k}
$$

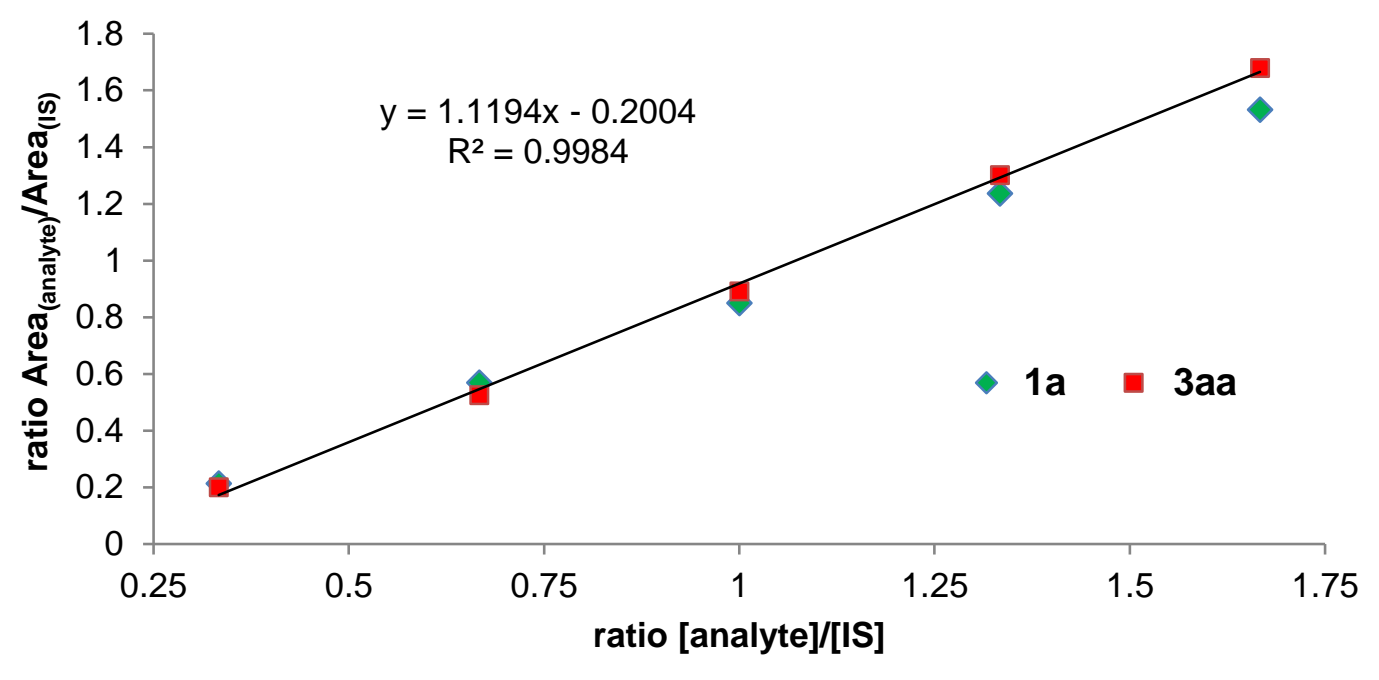

Figure S4. GC-FID calibration curve.

Table S2. Optimization of the residence time. Reactions were performed on $0.5 \mathrm{mmol}$ scale. ${ }^{[\mathrm{a}]}$ Conversions and yields were determined by GC-FID using $n$-dodecane as the internal standard.

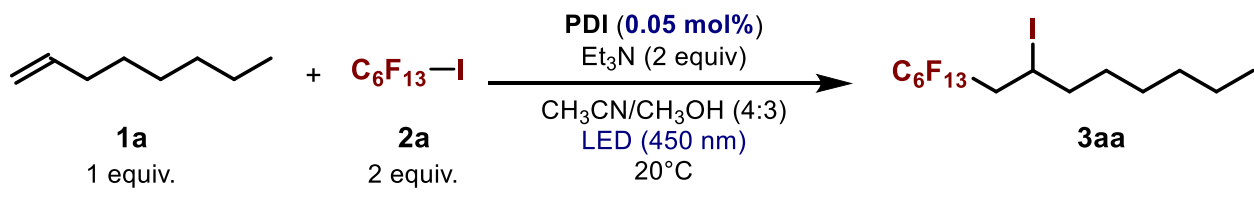

\begin{tabular}{|c|c|c|c|c|c|}
\hline Entry & Conc. & Flow Rate & Residence Time & Conv. ${ }^{[a]}$ & Yield $^{[a]}$ \\
\hline 1 & $0.1 \mathrm{M}$ & $0.554 \mathrm{~mL} / \mathrm{min}$ & $5 \mathrm{~min}$ & $>99 \%$ & $93 \%$ \\
\hline 2 & $0.1 \mathrm{M}$ & $1.108 \mathrm{~mL} / \mathrm{min}$ & $2.5 \mathrm{~min}$ & $99 \%$ & $91 \%$ \\
\hline 3 & $0.1 \mathrm{M}$ & $2.77 \mathrm{~mL} / \mathrm{min}$ & $1 \mathrm{~min}$ & $71 \%$ & $71 \%$ \\
\hline 4 & $0.1 \mathrm{M}$ & $5.54 \mathrm{~mL} / \mathrm{min}$ & $30 \mathrm{sec}$ & $30 \%$ & $26 \%$ \\
\hline
\end{tabular}


Table S3. Optimization of the triethylamine amount. Reactions were performed on $0.5 \mathrm{mmol}$ scale. ${ }^{[\mathrm{a}]}$ Conversions and yields were determined by GC-FID using $n$-dodecane as the internal standard.

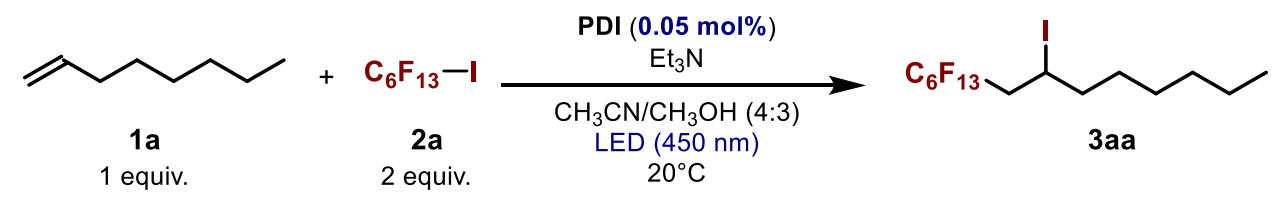

\begin{tabular}{|c|c|c|c|c|c|}
\hline Entry & Conc. & Residence Time & $\mathrm{Et}_{3} \mathrm{~N}$ & Conv. ${ }^{[a]}$ & Yield $^{[\mathrm{a}]}$ \\
\hline 1 & $0.1 \mathrm{M}$ & $5 \mathrm{~min}$ & 2 equiv & $>99 \%$ & $93 \%$ \\
\hline 2 & $0.1 \mathrm{M}$ & $5 \mathrm{~min}$ & 1 equiv & $>99 \%$ & $94 \%$ \\
\hline 3 & $0.1 \mathrm{M}$ & $5 \mathrm{~min}$ & 0.5 equiv & $>99 \%$ & $94 \%$ \\
\hline 4 & $0.1 \mathrm{M}$ & $5 \mathrm{~min}$ & 0.2 equiv & $>99 \%$ & $95 \%$ \\
\hline 5 & $0.1 \mathrm{M}$ & $5 \mathrm{~min}$ & 0.1 equiv & $98 \%$ & $93 \%$ \\
\hline
\end{tabular}

Table S4. Screening of the LEDs wavelength. Reactions were performed on $0.5 \mathrm{mmol}$ scale. ${ }^{[a]}$ Conversions and yields were determined by GC-FID using $n$-dodecane as the internal standard.

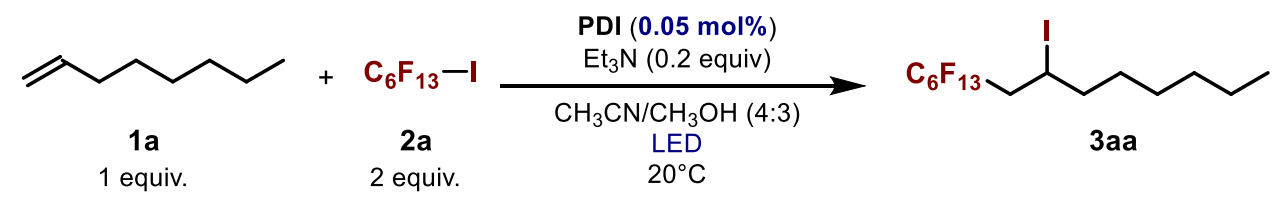

\begin{tabular}{c|cc|c|cc}
\cline { 5 - 5 } Entry & Conc. & Residence Time & Wavelength & Conv. ${ }^{[a]}$ & Yield $^{[a]}$ \\
\hline $\mathbf{1}$ & $0.1 \mathrm{M}$ & $5 \mathrm{~min}$ & $340 \mathrm{~nm}$ & $>99 \%$ & $95 \%$ \\
$\mathbf{2}$ & $0.1 \mathrm{M}$ & $5 \mathrm{~min}$ & $365 \mathrm{~nm}$ & $>99 \%$ & $95 \%$ \\
$\mathbf{3}$ & $0.1 \mathrm{M}$ & $5 \mathrm{~min}$ & $375 \mathrm{~nm}$ & $>99 \%$ & $94 \%$ \\
$\mathbf{4}$ & $0.1 \mathrm{M}$ & $5 \mathrm{~min}$ & $385 \mathrm{~nm}$ & $>99 \%$ & $97 \%$ \\
$\mathbf{5}$ & $0.1 \mathrm{M}$ & $5 \mathrm{~min}$ & $395 \mathrm{~nm}$ & $>99 \%$ & $96 \%$ \\
$\mathbf{6}$ & $0.1 \mathrm{M}$ & $5 \mathrm{~min}$ & $405 \mathrm{~nm}$ & $>99 \%$ & $97 \%$ \\
$\mathbf{7}$ & $0.1 \mathrm{M}$ & $5 \mathrm{~min}$ & $422 \mathrm{~nm}$ & $98 \%$ & $95 \%$ \\
$\mathbf{8}$ & $0.1 \mathrm{M}$ & $5 \mathrm{~min}$ & $450 \mathrm{~nm}$ & $>99 \%$ & $95 \%$ \\
$\mathbf{9}$ & $0.1 \mathrm{M}$ & $5 \mathrm{~min}$ & $485 \mathrm{~nm}$ & $>99 \%$ & $95 \%$ \\
$\mathbf{1 0}$ & $0.1 \mathrm{M}$ & $5 \mathrm{~min}$ & $540 \mathrm{~nm}$ & $90 \%$ & $88 \%$ \\
$\mathbf{1 1}$ & $0.1 \mathrm{M}$ & $5 \mathrm{~min}$ & $610 \mathrm{~nm}$ & $0 \%$ & $0 \%$ \\
$\mathbf{1 2}$ & $0.1 \mathrm{M}$ & $5 \mathrm{~min}$ & $4000 \mathrm{~K}$ & $98 \%$ & $90 \%$
\end{tabular}


Table S5. Optimization of the perfluorohexyl iodide amount. Reactions were performed on $0.5 \mathrm{mmol}$ scale. ${ }^{\text {[a] }}$ Conversions and yields were determined by GC-FID using $n$-dodecane as the internal standard.

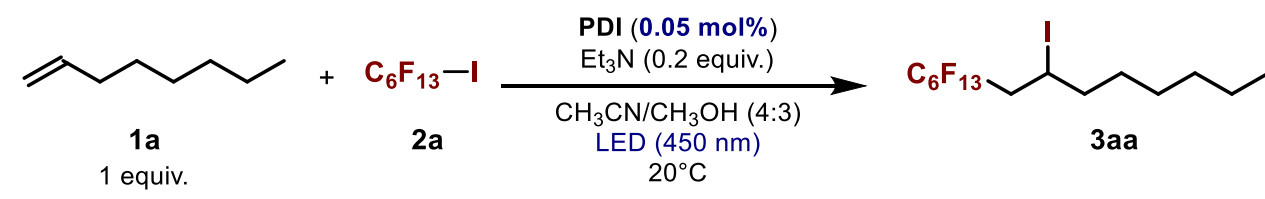

\begin{tabular}{|c|c|c|c|c|c|}
\hline Entry & Conc. & Residence Time & $\mathrm{C}_{6} \mathrm{~F}_{13} \mathrm{I}$ & Conv. ${ }^{[a]}$ & Yield $^{[\mathrm{a}]}$ \\
\hline 1 & $0.1 \mathrm{M}$ & $5 \mathrm{~min}$ & 2 equiv. & $>99 \%$ & $95 \%$ \\
\hline 2 & $0.1 \mathrm{M}$ & $5 \mathrm{~min}$ & 1.5 equiv. & $90 \%$ & $87 \%$ \\
\hline 3 & $0.1 \mathrm{M}$ & $5 \mathrm{~min}$ & 1.2 equiv. & $86 \%$ & $83 \%$ \\
\hline 4 & $0.1 \mathrm{M}$ & $5 \mathrm{~min}$ & 1 equiv. & $84 \%$ & $79 \%$ \\
\hline
\end{tabular}

Table S6. Optimization of the concentration with respect to alkene $1 \mathrm{~b}$. Reactions were performed on $0.5 \mathrm{mmol}$ scale. ${ }^{[a]}$ Conversions and yields were determined by GC-FID using $n$-dodecane as the internal standard. ${ }^{[b]} 1 \mathrm{mmol}$ scale reaction. Isolated yield in parentheses.

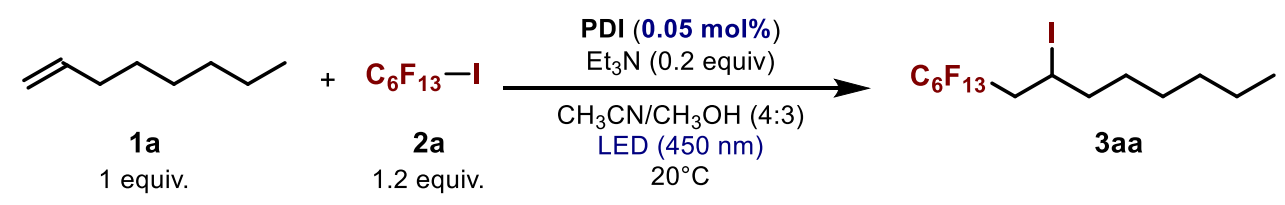

\begin{tabular}{c|cccc} 
Entry & Conc. & Residence Time & Conv. $^{[\mathrm{a}]}$ & Yield $^{[\mathrm{a}]}$ \\
\hline 1 & $0.1 \mathrm{M}$ & $5 \mathrm{~min}$ & $86 \%$ & $83 \%$ \\
$\mathbf{2}^{[\mathrm{bb}]}$ & $0.2 \mathrm{M}$ & $5 \mathrm{~min}$ & $99 \%$ & $95 \%(85 \%)$
\end{tabular}

\section{D2. Optimization of the Reaction Conditions at $405 \mathrm{~nm}$ in Absence of PDI}

Prior to evaluating the synthetic potential of the transformation, a series of optimization studies were performed using 1-octene (1a) and perfluorohexyl iodide (2a) as model reagents in order to explore the reaction parameters. These experiments were carried out following General Procedure $\mathbf{C 2}$. 
Table S7. Screening of the LEDs wavelength. Reactions were performed on $0.5 \mathrm{mmol}$ scale. ${ }^{[\mathrm{a}]}$ Conversions and yields were determined by GC-FID using $n$-dodecane as the internal standard.

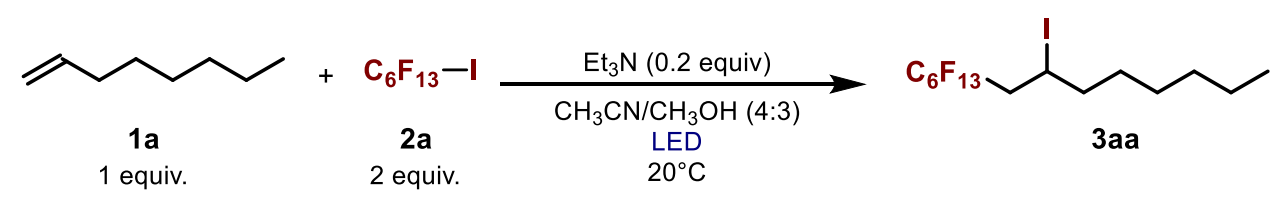

\begin{tabular}{|c|c|c|c|c|c|}
\hline Entry & Conc. & Residence Time & Wavelength & Conv. ${ }^{[a]}$ & Yield $^{[a]}$ \\
\hline 1 & $0.1 \mathrm{M}$ & $5 \mathrm{~min}$ & $340 \mathrm{~nm}$ & $>99 \%$ & $94 \%$ \\
\hline 2 & $0.1 \mathrm{M}$ & $5 \mathrm{~min}$ & $365 \mathrm{~nm}$ & $>99 \%$ & $94 \%$ \\
\hline 3 & $0.1 \mathrm{M}$ & $5 \mathrm{~min}$ & $375 \mathrm{~nm}$ & $>99 \%$ & $97 \%$ \\
\hline 4 & $0.1 \mathrm{M}$ & $5 \mathrm{~min}$ & $385 \mathrm{~nm}$ & $>99 \%$ & $94 \%$ \\
\hline 5 & $0.1 \mathrm{M}$ & $5 \mathrm{~min}$ & $395 \mathrm{~nm}$ & $>99 \%$ & $94 \%$ \\
\hline 6 & $0.1 \mathrm{M}$ & $5 \mathrm{~min}$ & $405 \mathrm{~nm}$ & $>99 \%$ & $94 \%$ \\
\hline 7 & $0.1 \mathrm{M}$ & $5 \mathrm{~min}$ & $422 \mathrm{~nm}$ & $40 \%$ & $34 \%$ \\
\hline 8 & $0.1 \mathrm{M}$ & $5 \mathrm{~min}$ & $450 \mathrm{~nm}$ & $0 \%$ & $0 \%$ \\
\hline 9 & $0.1 \mathrm{M}$ & $5 \mathrm{~min}$ & $485 \mathrm{~nm}$ & $0 \%$ & $0 \%$ \\
\hline 10 & $0.1 \mathrm{M}$ & $5 \min$ & $540 \mathrm{~nm}$ & $0 \%$ & $0 \%$ \\
\hline 11 & $0.1 \mathrm{M}$ & $5 \mathrm{~min}$ & $610 \mathrm{~nm}$ & $0 \%$ & $0 \%$ \\
\hline
\end{tabular}

Table S8. Screening of the solvents. Reactions were performed on $0.5 \mathrm{mmol}$ scale. ${ }^{[\mathrm{a}]}$ Conversions and yields were determined by GC-FID using $n$-dodecane as the internal standard.

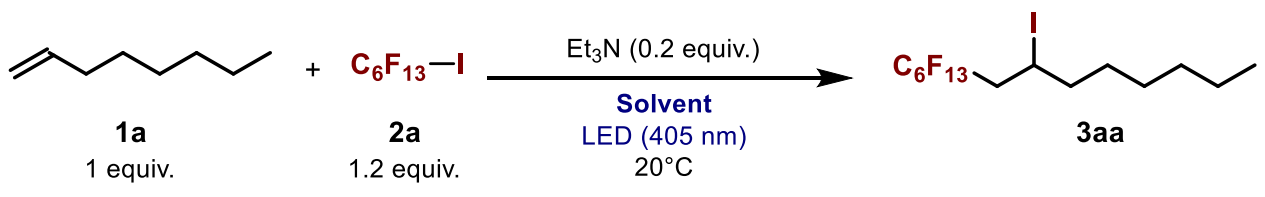

\begin{tabular}{|c|c|c|c|c|c|}
\hline Entry & Conc. & Residence Time & Solvent & Conv. ${ }^{[a]}$ & Yield $^{[a]}$ \\
\hline 1 & $0.1 \mathrm{M}$ & $5 \min$ & $\mathrm{CH}_{3} \mathrm{CN} / \mathrm{CH}_{3} \mathrm{OH}(4: 3)$ & $84 \%$ & $82 \%$ \\
\hline 2 & $0.1 \mathrm{M}$ & $5 \mathrm{~min}$ & $\mathrm{CH}_{3} \mathrm{CN} / \mathrm{CH}_{3} \mathrm{OH}(9: 1)$ & $95 \%$ & $90 \%$ \\
\hline 3 & $0.1 \mathrm{M}$ & $5 \mathrm{~min}$ & $\mathrm{CH}_{3} \mathrm{CN}$ & $96 \%$ & $92 \%$ \\
\hline
\end{tabular}


Table S9. Screening of the reaction concentration with respect to alkene 1a. Isolated yields after chromatography purification. Reactions were performed on ${ }^{[a]} 1.25 \mathrm{mmol} \mathrm{scale},{ }^{[\mathrm{b}]} 1.5 \mathrm{mmol}$ scale and ${ }^{[\mathrm{c}]} 2.5 \mathrm{mmol}$ scale.

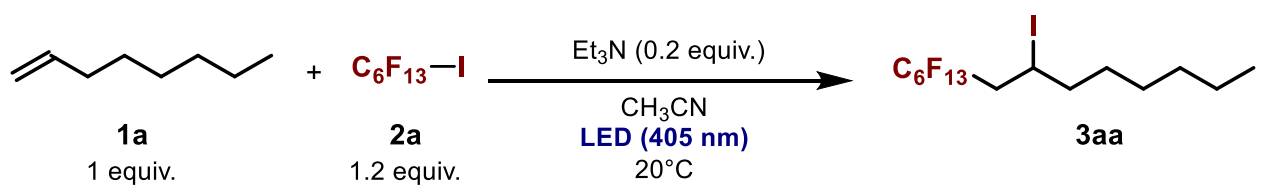

\begin{tabular}{c|ccc|} 
Entry & Conc. & Residence Time & Isolated Yield \\
\hline $\mathbf{1}^{[\mathrm{a}]}$ & $0.25 \mathrm{M}$ & $5 \mathrm{~min}$ & $95 \%$ \\
$\mathbf{2}^{[\mathrm{b}]}$ & $0.3 \mathrm{M}$ & $5 \mathrm{~min}$ & $83 \%$ \\
$\mathbf{3}^{[\mathrm{c}]}$ & $0.5 \mathrm{M}$ & $5 \mathrm{~min}$ & $78 \%$ \\
\hline
\end{tabular}

Perfluorohexyl iodide (2a) is poorly soluble in acetonitrile at concentrations higher than $0.25 \mathrm{M}$ with respect to alkene 1a. 


\section{E. Mechanistic Investigations}

\section{E1. Determination of Binding Stoichiometry and Association Constant by ${ }^{19}$ F NMR}

${ }^{19} \mathrm{~F}$ NMR spectra of seven mixtures of perfluorohexyl iodide (2a) and triethylamine (TEA) were recorded in the $\mathrm{CD}_{3} \mathrm{CN}$. Fluorobenzene was used as the internal standard $(25 \mu \mathrm{L}, \delta=-114.85 \mathrm{ppm})$. The total volume of the solution was $0.7 \mathrm{~mL}$. The total amount of $2 \mathbf{a}$ and TEA was kept constant at $0.35 \mathrm{mmol}(0.5 \mathrm{M})$. The amount of $2 \mathbf{a}$ was varied from 0 to $0.35 \mathrm{mmol}$, corresponding to $0.0,0.2,0.4,0.5,0.6,0.8,1.0$ molar ratio. The chemical shift difference $(\Delta \delta)$ between $-\mathrm{CF}_{2} \mathrm{I}$ in the different mixtures was calculated and the binding stoichiometry was then determined using Job's plot analysis, ${ }^{, 15}$ plotting $[2 \mathrm{a}] /[2 \mathrm{a}+\mathrm{TEA}] v s[2 \mathrm{a}] \times \Delta \delta$. 


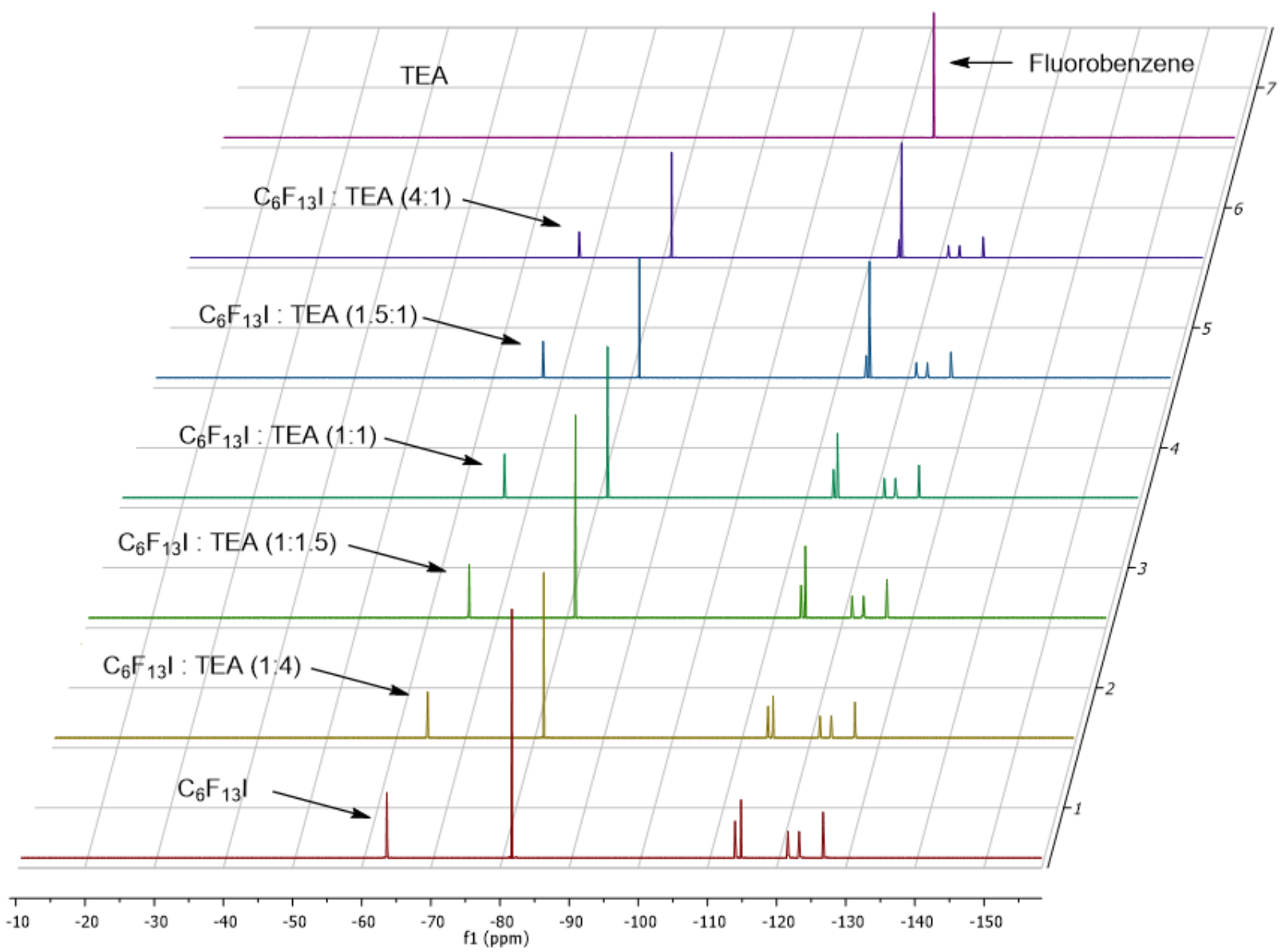

Figure S5. ${ }^{19} \mathrm{~F}-\mathrm{NMR}$ spectra showing the $\Delta \delta$ of the various $\mathrm{C}_{6} \mathrm{~F}_{13} \mathrm{I}$ and TEA mixtures.

Table S10. Experimental data for Job plot analysis.

$\begin{array}{cccccc}\text { Molar Ratio } & {[\mathbf{2 a}]} & \text { [TEA] } & \mathbf{\Delta} \boldsymbol{\delta} & \text { [2a]/[2a + TEA] } & {[\mathbf{2 a}] \times \mathbf{\Delta} \boldsymbol{\delta}} \\ 0.0 & 0 & 0.5 & 0 & 0 & 0 \\ 0.2 & 0.1 & 0.4 & 4.58 & 0.2 & 0.458 \\ 0.4 & 0.2 & 0.3 & 4 & 0.4 & 0.8 \\ 0.5 & 0.25 & 0.25 & 3.08 & 0.5 & 0.77 \\ 0.6 & 0.3 & 0.2 & 2.61 & 0.6 & 0.783 \\ 0.8 & 0.4 & 0.1 & 1.25 & 0.8 & 0.5 \\ 1.0 & 0.5 & 0 & 0 & 1 & 0\end{array}$




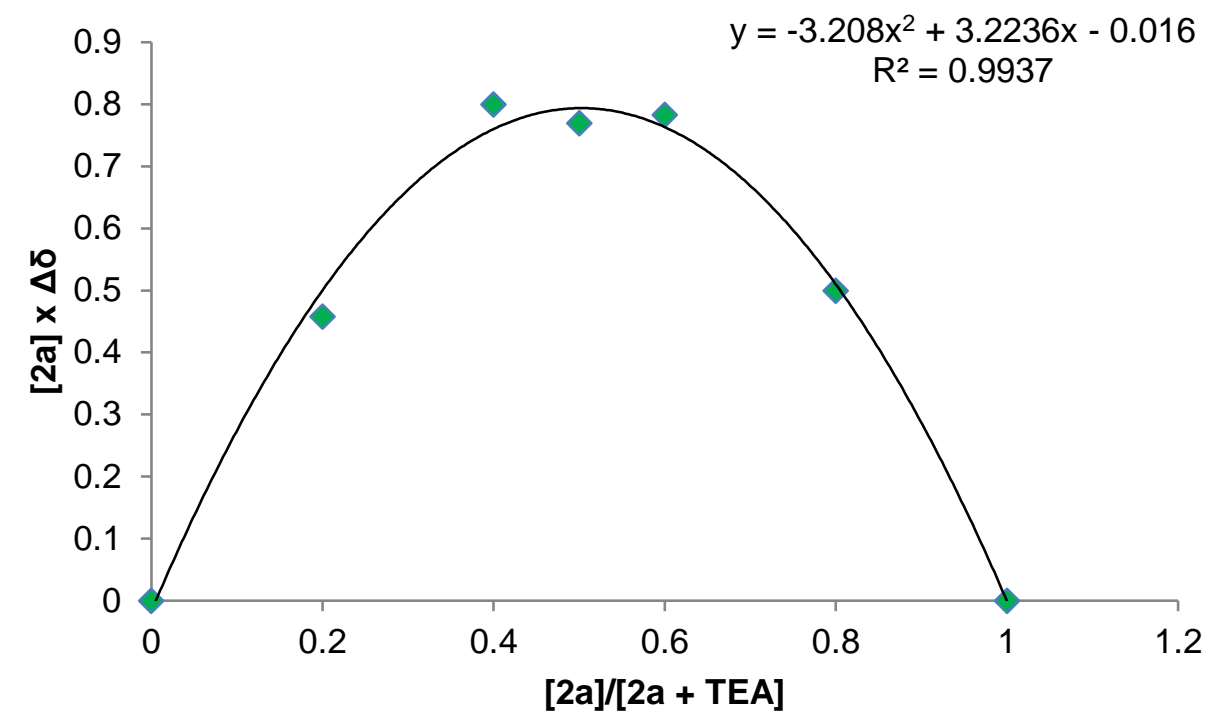

Figure S6. Job's plot analysis.

$$
x_{\max }=\frac{3.223}{-2 \times(-3.208)}=0.50
$$

The Job plot analysis has demonstrated that 2a and TEA are associated in 1:1 ratio complex ratio through halogen bonding.

Finally, the association constant (Ka) of the complex has been calculated using Hanna and Ashbaugh's method. ${ }^{\mathrm{S} 16}{ }^{19} \mathrm{~F}$ NMR spectra of seven mixtures of perfluorohexyl iodide (2a) and triethylamine (TEA) were recorded in the $\mathrm{CD}_{3} \mathrm{CN}$. Fluorobenzene was used as the internal standard $(25 \mu \mathrm{L}, \delta=-114.85 \mathrm{ppm})$. The total volume of the solution was $0.7 \mathrm{~mL}$. The amount of 2a was kept constant at $0.1 \mathrm{mmol}(0.143 \mathrm{M})$. The amount of TEA was varied from 0 to $3 \mathrm{mmol}$, corresponding to $0,1,1.5,3,6,12,30$ equivalents with respect to $2 \mathbf{a}$. The chemical shift difference $(\Delta \delta)$ between $-\mathrm{CF}_{2} \mathrm{I}$ in the different mixtures was calculated and the binding stoichiometry was then determined plotting $1 /[\mathrm{TEA}]$ vs $1 / \Delta \delta$.

Table S11. Experimental data for association constant determination.

\begin{tabular}{cccccc} 
Entry & {$[\mathbf{2 a}]$} & {$[\mathbf{T E A}]$} & $\mathbf{1 / [ T E A ]}$ & $\boldsymbol{\Delta \boldsymbol { \delta }}$ & $\mathbf{1 / \Delta \boldsymbol { \delta }}$ \\
\hline 1 & 0.143 & 0.00 & 0.00 & 0 & 0.00 \\
2 & 0.143 & 0.14 & 7.00 & 2.16 & 0.46 \\
3 & 0.143 & 0.21 & 4.67 & 2.98 & 0.34 \\
4 & 0.143 & 0.43 & 2.33 & 4.9 & 0.20 \\
5 & 0.143 & 0.86 & 1.17 & 6.92 & 0.14 \\
6 & 0.143 & 1.71 & 0.58 & 8.74 & 0.11 \\
7 & 0.143 & 4.29 & 0.23 & 9.77 & 0.10 \\
\hline
\end{tabular}




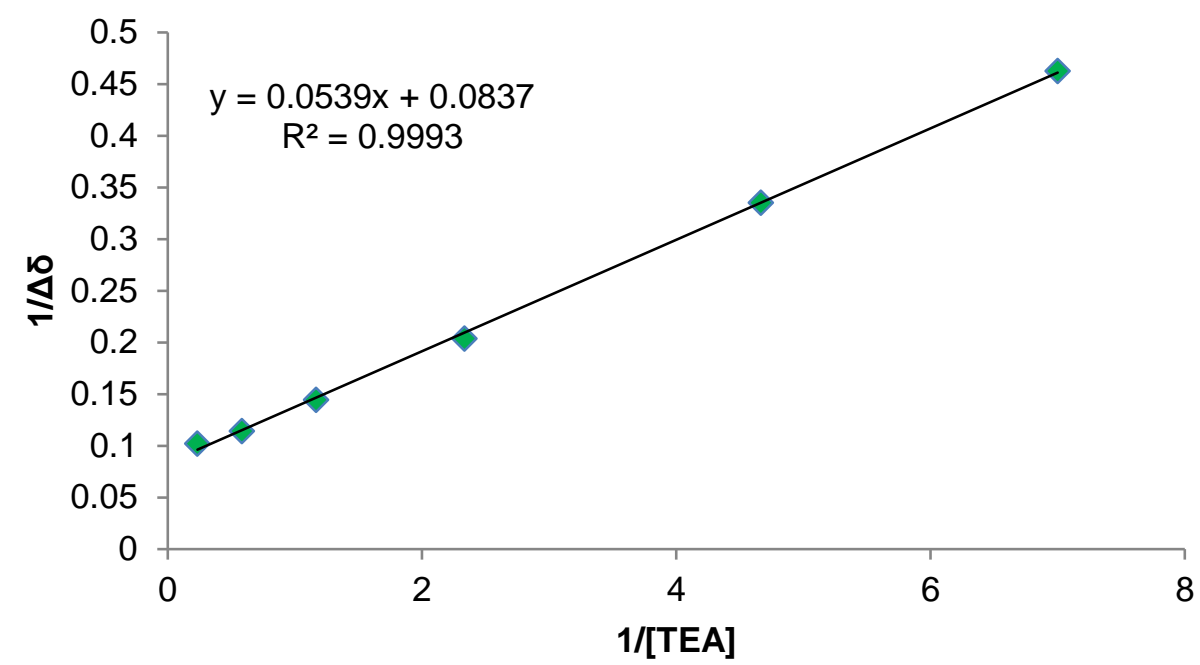

Figure S7. Association constant determination.

$$
K_{a}=\frac{\text { intercept }}{\text { slope }}=\frac{0.0837}{0.0539}=1.57 M^{-1}
$$

The association constant between $2 \mathrm{a}$ and TEA was calculated to be $1.57 \mathrm{M}^{-1}$ in $\mathrm{CD}_{3} \mathrm{CN}$.

\section{E2. Kinetic profile and UV-Vis experiments}

To determine the kinetic profile of the model reaction between 1a and 2a in presence of TEA as amine additive, the general procedure $\mathbf{C 2}$ was followed, adjusting the flow rate of the solvent to provide the corresponding residence time.

Table S12. Kinetic profile determination. ${ }^{[a]}$ Conversion was determined by GC-FID using $n$-dodecane as the internal standard.

$\begin{array}{cccc}\text { Entry } & \begin{array}{c}\text { Flow Rate } \\ (\mathbf{m L} / \mathbf{m i n})\end{array} & \begin{array}{c}\text { Residence } \\ \text { Time }(\mathbf{s})\end{array} & \text { Conv. }(\%)^{[\mathrm{a}]} \\ 1 & 0 & 0 & 0 \\ 2 & 9.78 & 17 & 0 \\ 3 & 5.54 & 30 & 46 \\ 4 & 2.77 & 60 & 74 \\ 5 & 1.85 & 90 & 84 \\ 6 & 1.38 & 120 & 87 \\ 7 & 1.11 & 150 & 89 \\ 8 & 0.92 & 180 & 90 \\ 9 & 0.79 & 210 & 91 \\ 10 & 0.69 & 240 & 92 \\ 11 & 0.62 & 270 & 93\end{array}$




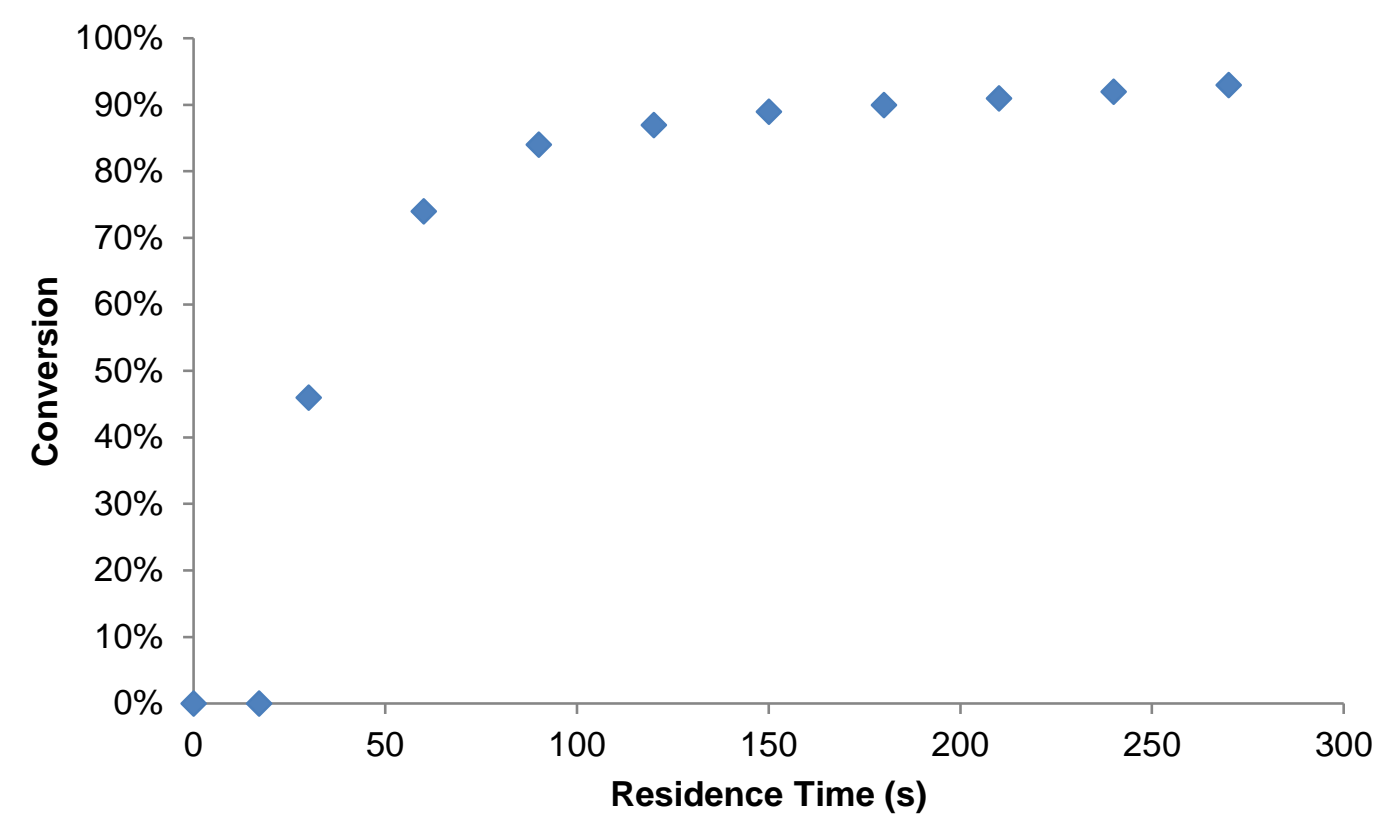

Figure S8. Kinetic profile of the model reaction performed in flow, irradiated at $405 \mathrm{~nm}$, without PDI.

The reaction under these conditions has an induction period of at least 30 seconds.

UV-Vis experiments of the crude mixture in acetonitrile highlighted the formation of five different bands during the reaction progress. Two of which are present in the UV region $(250$ and $350 \mathrm{~nm})$ and three are centered in the visible $(440,500$ and $570 \mathrm{~nm})$. The first set of signals is observed using a concentration of $0.0025 \mathrm{M}$ with respect to the alkene 1a and the second set is clearly observable at $0.025 \mathrm{M}$. The reactor output was diluted accordingly, to reach the required concentration.

For comparison, the spectrum of the pure product 3aa is also shown $\left(\lambda_{\max }=265 \mathrm{~nm}\right)$. 


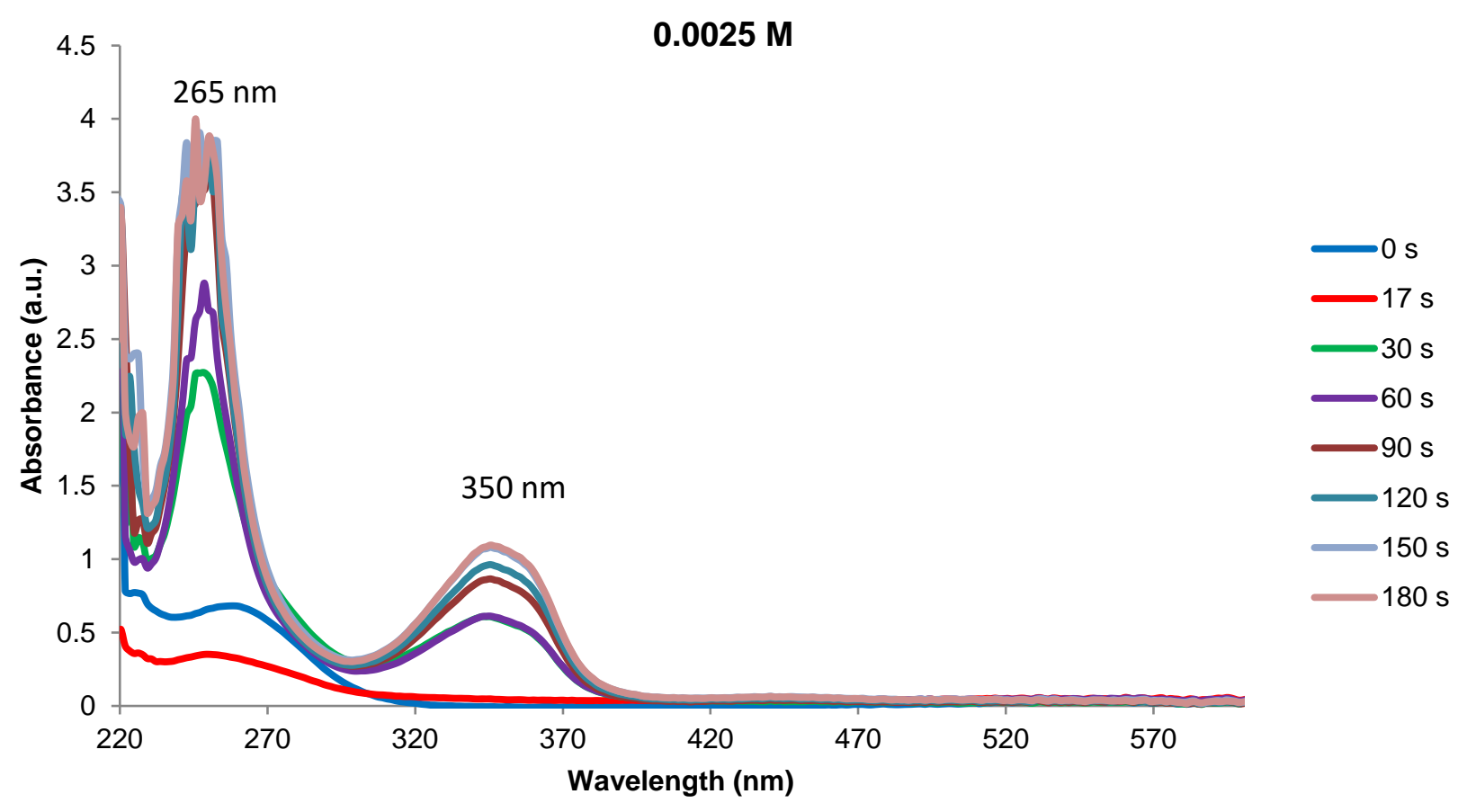

Figure S9. Optical absorption spectra of the reaction output obtained at different residence times. Recorded in acetonitrile $(0.0025 \mathrm{M})$. Optical path length $=1 \mathrm{~cm}$.

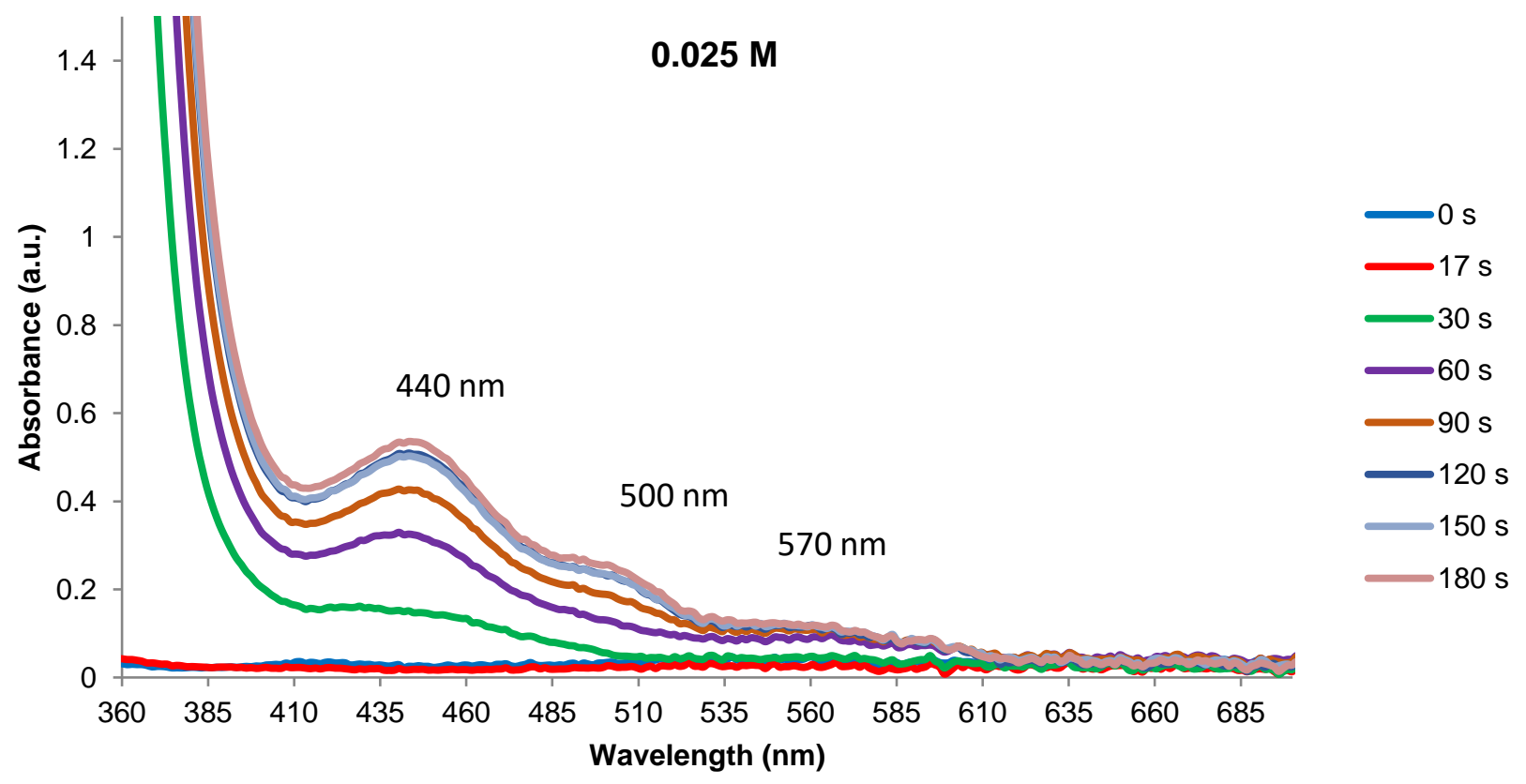

Figure S10. Optical absorption spectra of the reaction output obtained at different residence times. Recorded in acetonitrile $(0.025 \mathrm{M})$ Optical path length $=1 \mathrm{~cm}$. 


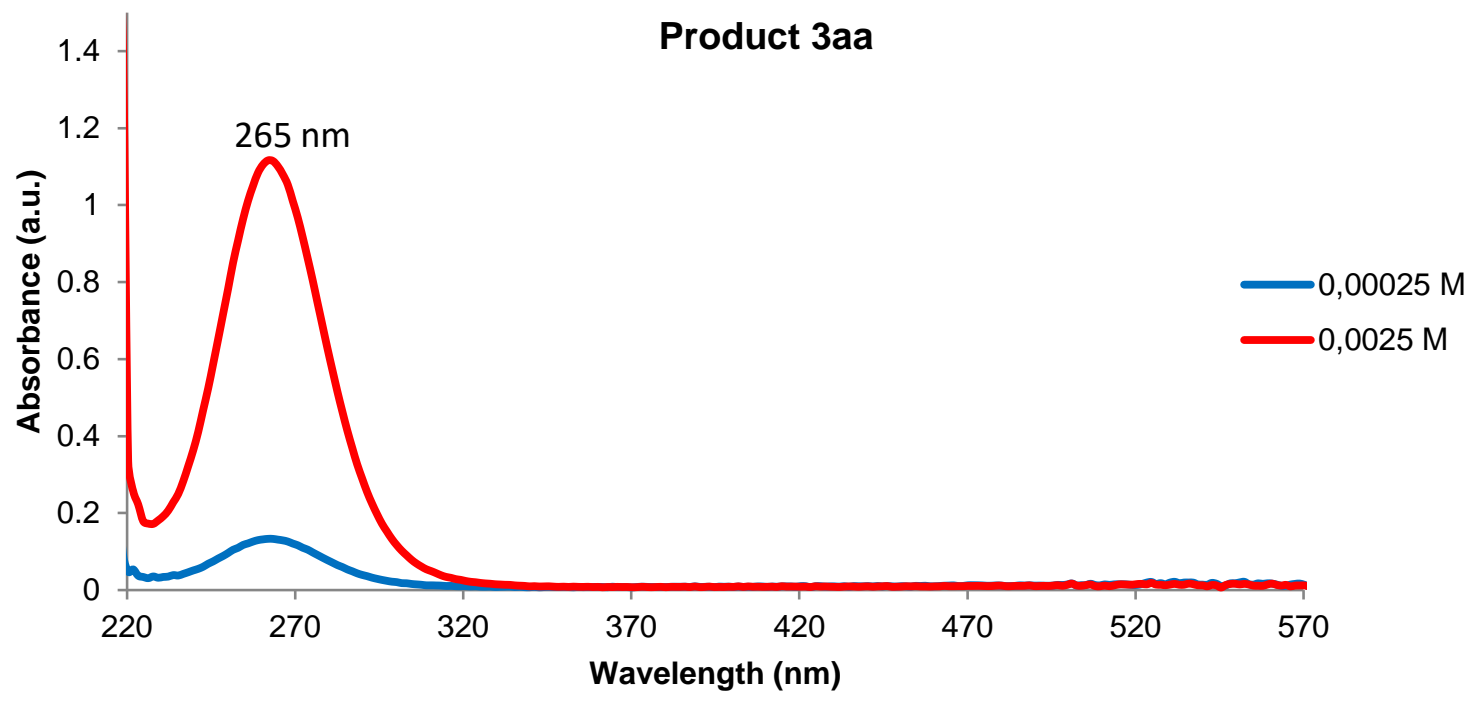

Figure S11. Optical absorption spectra recorded in acetonitrile of the pure product 3aa in acetonitrile at $0.00025 \mathrm{M}$ (blue line) and $0.0025 \mathrm{M}$ (red line). Optical path length $=1 \mathrm{~cm}$. 


\section{F. Fulvestrant Side Chain Synthesis}

\section{F1. Dehalogenation of 3ee}

An H-CUBE Pro (ThalesNano Inc.) system was used for this procedure. The H-CUBE Pro has an internal hydrogen generator, then this hydrogen is introduced into the reaction mixture, which is pumped by an HPLC pump, prior to catalyst contact. The pressure of the system is dictated by the adjustable BPR (back pressure regulator). The system can be summarized by the following scheme:

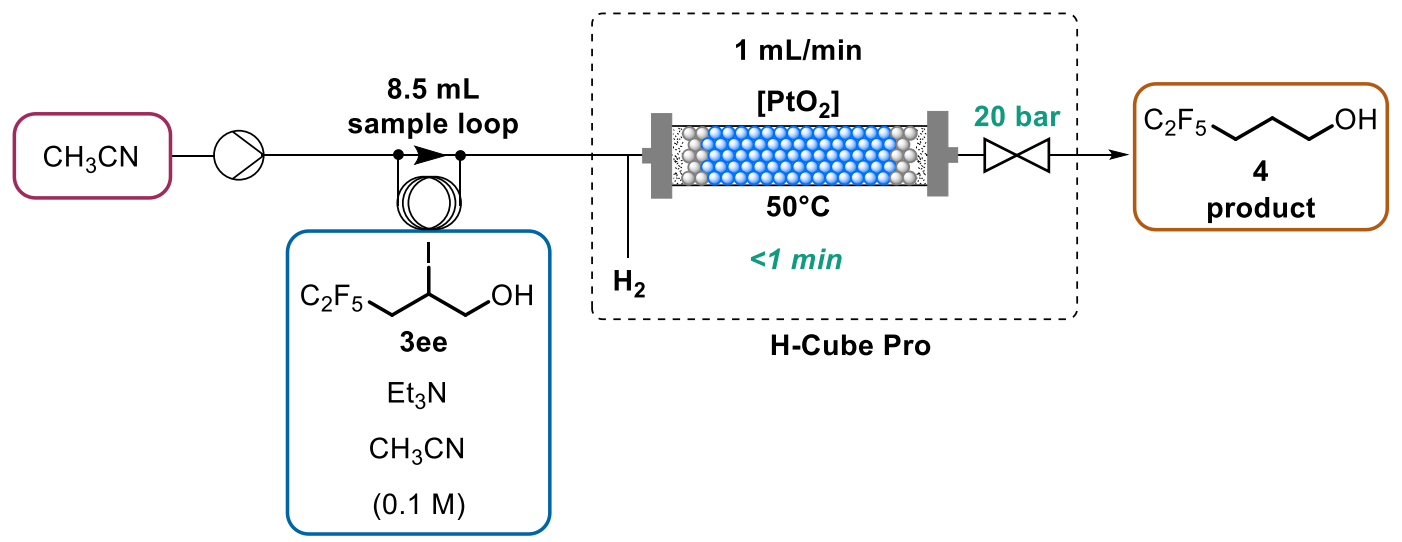

Scheme S3. Flow diagram showing the reaction setup for dehalogenation of 3ee.

The crude mixture of 3ee in acetonitrile (theoretically $1.25 \mathrm{mmol}, 1$ equiv) coming from the Corning PhotoReactor was collected and diluted with acetonitrile to $0.1 \mathrm{M}$ and sparged with argon for $30 \mathrm{~min}$ to remove the unreacted trifluoroiodomethane. Triethylamine $(2.5 \mathrm{mmol}, 348 \mu \mathrm{L}, 2$ equiv $)$ was then added and the resulting solution was loaded into an $8.5 \mathrm{~mL}$ injection loop (fitted to an Upchurch 6-way valve). Acetonitrile was pumped through the H-CUBE Pro reactor at $1 \mathrm{~mL} / \mathrm{min}$ flow rate, corresponding to less than $1 \mathrm{~min}$ residence time. The system was equipped with a $\mathrm{PtO}_{2}$ cartridge $\left(70 \mathrm{~mm}, 4 \mathrm{~mm}\right.$ diameter), heated up to $50{ }^{\circ} \mathrm{C}$, pressurized to 20 bar by the adjustable back pressure regulator and set to " $100 \%$ hydrogen amount". After allowing the reactor to equilibrate for roughly $30 \mathrm{~min}$, the reaction mixture was injected from the sample loop. The output was collected and used directly in the following step without isolation nor purification of the dehalogenated alcohol 4.

\section{F2. Benzoylation of 4 performed in batch}

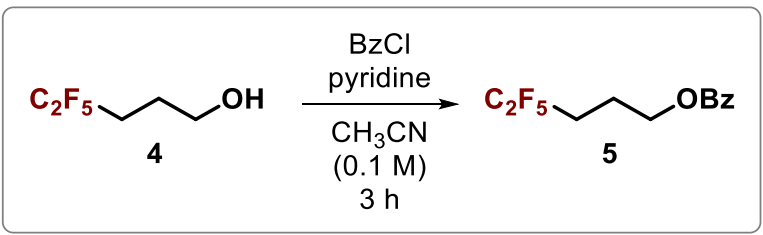

Scheme S4. Benzoylation of alcohol 4.

To the crude mixture of $\mathbf{4}$ in acetonitrile (theoretically 1,25 mmol, 1 equiv) coming from the H-CUBE Pro 
reactor was added pyridine $\left(10 \mathrm{mmol}, 809 \mu \mathrm{L}, 8\right.$ equiv) and the solution was stirred at $0{ }^{\circ} \mathrm{C}$ for $10 \mathrm{~min}$. Benzoyl chloride $(6.25 \mathrm{mmol}, 726 \mu \mathrm{L}, 5$ equiv) was added dropwise and the solution was stirred at room temperature for 3 hours. The reaction was quenched by the addition of $\mathrm{HCl} 1 \mathrm{M}(20 \mathrm{~mL})$ and then extracted with ethyl acetate $(3 \times 20 \mathrm{~mL})$. The organic phases were combined and dried over sodium sulfate. The solvent was removed under reduced pressure and the residue was purified by column chromatography (petroleum ether/ethyl acetate 95:5) to give the corresponding benzoylated alcohol $\mathbf{5}$ as a pale yellow oil (253 mg, 72\% overall yield).

${ }^{1} \mathrm{H}-\mathrm{NMR}\left(300 \mathrm{MHz}, \mathrm{CDCl}_{3}\right) \delta 8.08-8.01(\mathrm{~m}, 2 \mathrm{H}), 7.62-7.53(\mathrm{~m}, 1 \mathrm{H}), 7.49-7.41(\mathrm{~m}, 2 \mathrm{H}), 4.40(\mathrm{t}, J=6.1 \mathrm{~Hz}$, 2H), 2.33-2.02 (m, 4H); ${ }^{13} \mathrm{C}-\mathrm{NMR}\left(75 \mathrm{MHz}, \mathrm{CDCl}_{3}\right) \delta 166.44(\mathrm{~s}), 133.26(\mathrm{~s}), 129.67$ (s), $128.56(\mathrm{~s}), 63.49$ (s), $27.84(\mathrm{t}, J=22.3 \mathrm{~Hz}), 20.35(\mathrm{t}, J=3.8 \mathrm{~Hz}) ;{ }^{19} \mathrm{~F}\left(282 \mathrm{MHz}, \mathrm{CDCl}_{3}\right) \delta-85.51(\mathrm{~s}),-118.32(\mathrm{t}, J=17.8 \mathrm{~Hz})$;

IR (ATR, neat, $\mathrm{cm}^{-1}$ ): 1720, 1271, 1188, 1109, 1025, 997, 705; HRMS (APCI+APPI, positive mode) calculated for $\mathrm{C}_{12} \mathrm{H}_{12} \mathrm{O}_{2} \mathrm{~F}_{5}[\mathrm{M}+\mathrm{H}]^{+}:$283.0757, found: 283.0748 .

\section{F3. Scale-out Synthesis of 5}

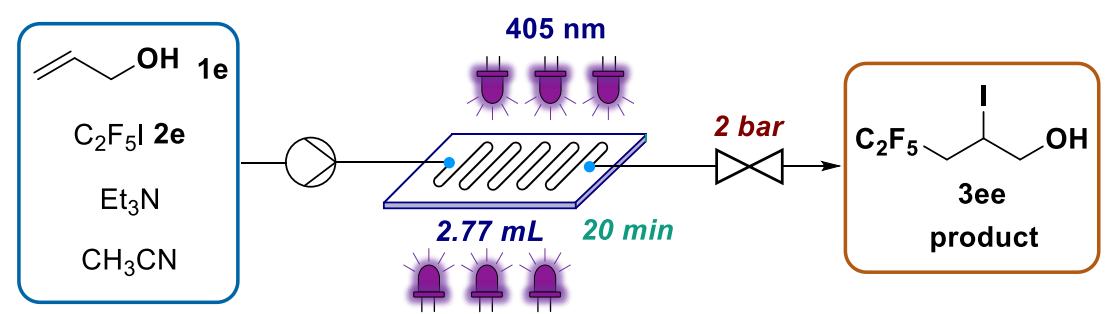

Scheme S5. Flow diagram showing the reaction setup for scale-out synthesis of $\mathbf{3 0}$.

The 40 LED array was switched on at $405 \mathrm{~nm}$ and its thermal fluid was set to $15^{\circ} \mathrm{C}$. The reaction plate thermostat was set to $20^{\circ} \mathrm{C}$. A solution of allyl alcohol 1e (12.5 mmol, 1 equiv), pentafluoroiodoethane $2 \mathrm{e}$ (50 mmol, 4 equiv, taken from a $2 \mathrm{M}$ solution in acetonitrile), and triethylamine (2.5 mmol, 0.2 equiv) was made up in degassed acetonitrile $(50 \mathrm{~mL}$ total volume in a volumetric flask, solvent was degassed prior to use by sparging with argon for 15 minutes, $[1 \mathbf{e}]_{0}=0.25 \mathrm{M}$ ). Using a Zaiput back pressure regulator, a pressure of 3 bar was set. The reaction solution was pumped through the $2.77 \mathrm{~mL}$ reaction plate at $0.139 \mathrm{~mL} / \mathrm{min}$ flow rate, corresponding to $20 \mathrm{~min}$ residence time. After allowing the reactor to equilibrate for roughly $15 \mathrm{~min}$, the processed mixture, containing compound 3ee, was collected over a run time of $173 \mathrm{~min}$ (24 mL, $6 \mathrm{mmol}$ theoretical yield). 


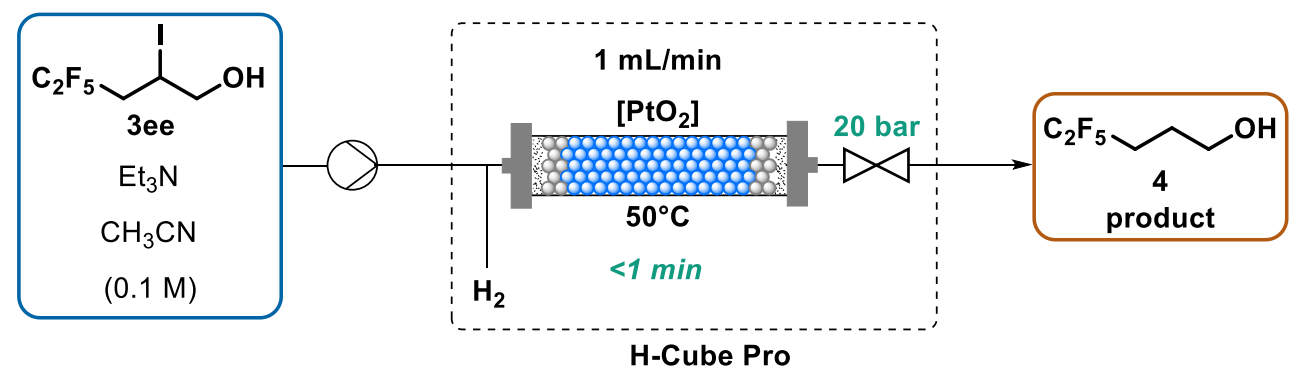

Scheme S6. Flow diagram showing the reaction setup for scale-out synthesis of $\mathbf{4}$.

The crude mixture of $\mathbf{3 o}$ in acetonitrile ( $24 \mathrm{~mL}$, theoretically $6 \mathrm{mmol}, 1$ equiv) coming from the Corning Photo-Reactor was diluted with acetonitrile to $0.1 \mathrm{M}$ and sparged with argon for $30 \mathrm{~min}$ to remove the unreacted trifluoroiodomethane. Triethylamine $(12 \mathrm{mmol}, 1.67 \mathrm{~mL}, 2$ equiv) was then added and the resulting solution was pumped through the $\mathrm{H}-\mathrm{CUBE}$ Pro reactor at $1 \mathrm{~mL} / \mathrm{min}$ flow rate, corresponding to less than $1 \mathrm{~min}$ residence time. The system was equipped with a $\mathrm{PtO}_{2}$ cartridge ( $70 \mathrm{~mm}, 4 \mathrm{~mm}$ diameter), heated to $50{ }^{\circ} \mathrm{C}$, pressurized to 20 bar by the adjustable back pressure regulator and set to " $100 \%$ hydrogen amount". The output was collected and used directly in the following step without isolation nor purification of the dehalogenated alcohol 4 (6 mmol theoretical yield).

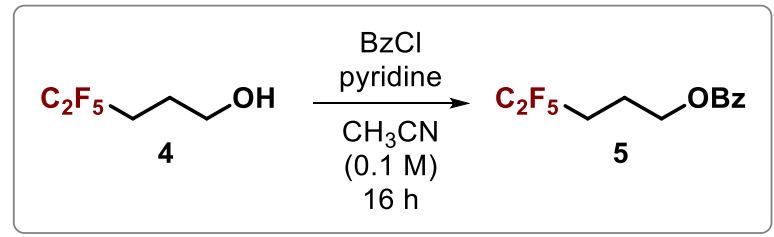

Scheme S7. Larger scale benzoylation of alcohol 4.

To the crude mixture of $\mathbf{4}$ in acetonitrile ( $6 \mathrm{mmol}, 1$ equiv) coming from the H-CUBE Pro reactor was added pyridine (48 mmol, $3.88 \mathrm{~mL}, 8$ equiv) and stirred at $0{ }^{\circ} \mathrm{C}$ for $10 \mathrm{~min}$. Benzoyl chloride ( $30 \mathrm{mmol}, 3.49 \mathrm{~mL}$, 5 equiv) was added dropwise and the solution was stirred at room temperature for $16 \mathrm{~h}$. The reaction was quenched by the addition of $\mathrm{HCl}(1 \mathrm{M}, 100 \mathrm{~mL})$ and then extracted with ethyl acetate $(3 \times 100 \mathrm{~mL})$. The organic phases were combined and dried over sodium sulfate. The solvent was removed under reduced pressure and the residue was purified by column chromatography (petroleum ether/ethyl acetate 95:5) to give the corresponding benzoylated alcohol $\mathbf{5}$ as a pale yellow oil (1.23 g, 73\% yield over 3 steps). 


\section{H. References}

(S1) Knowles, J. P.; Elliott, L. D.; Booker-Milburn, K. I. Beilstein J. Org. Chem. 2012, 8, 2025.

(S2) Regar, R.; Mishra, R.; Mondal, P. K.; Sankar, J. J. Org. Chem. 2018, 83, 9547.

(S3) Cao, L.; Li, C. Tetrahedron Lett. 2008, 49, 7380.

(S4) Davis, C. R.; Burton, D. J.; Yang, Z. Y. J. Fluor. Chem. 1995, 70, 135.

(S5) Yajima, T.; Ikegami, M. Eur. J. Org. Chem. 2017, 2126.

(S6) Lahiouhel, D.; Ameduri, B.; Boutevin, B. J. Fluor. Chem. 2001, 107, 81.

(S7) Vázquez, A. J.; Nudelman, N. S. Arkivoc 2015, 2015, 190.

(S8) Zeng, R.; Fu, C.; Ma, S. Angew. Chem. Int. Ed. 2012, 51, 3888.

(S9) Beniazza, R.; Remisse, L.; Jardel, D.; Lastécouères, D.; Vincent, J. M. Chem. Commun. 2018, 54,7451 .

(S10) Deng, W.; Li, Y.; Li, Y. G.; Bao, H. Synthesis 2018, 50, 2974.

(S11) Yoshioka, E.; Kohtani, S.; Jichu, T.; Fukazawa, T.; Nagai, T.; Kawashima, A.; Takemoto, Y.; Miyabe, H. J. Org. Chem. 2016, 81, 7217.

(S12) Du, Y.; Pearson, R. M.; Lim, C. H.; Sartor, S. M.; Ryan, M. D.; Yang, H.; Damrauer, N. H.; Miyake, G. M. Chem. Eur. J. 2017, 23, 10962.

(S13) Beniazza, R.; Douarre, M.; Lastécouères, D.; Vincent, J. M. Chem. Commun. 2017, 53, 3547.

(S14) Li, X.; Provencher, L.; Singh, S. M. Tetrahedron Lett. 1994, 35, 9141.

(S15) Job, P. Justus Liebigs Ann. Chem. 1928, 9, 113.

(S16) Hanna, M. W.; Ashbaugh, A. L. J. Phys. Chem. 1964, 68, 811. 


\section{NMR Spectra}

wb_CRR_prod3b

m

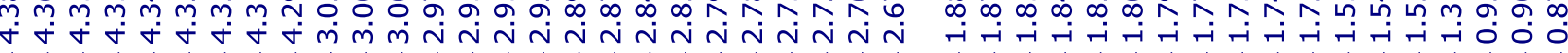

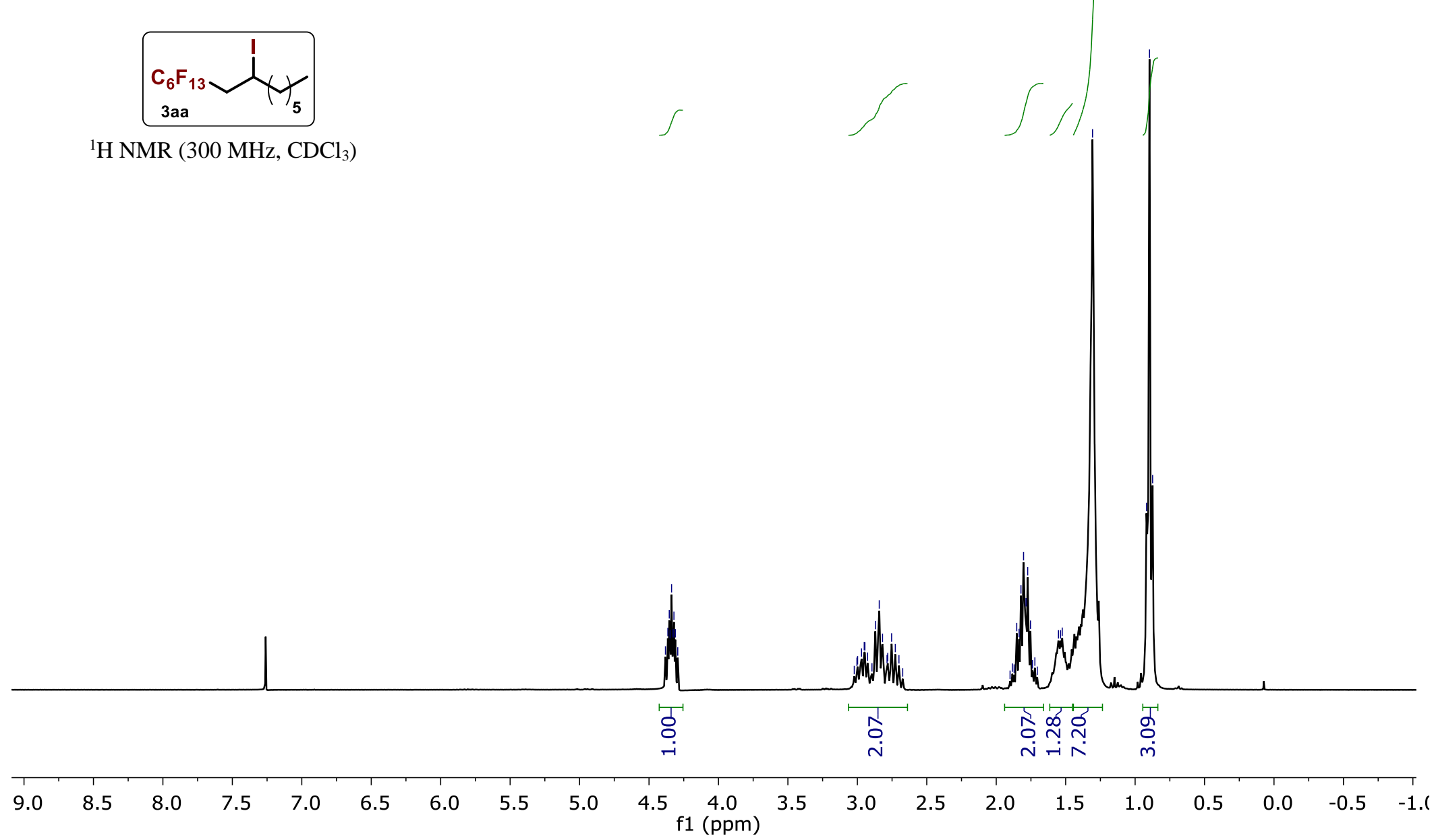

${ }^{1} \mathrm{H} \mathrm{NMR}\left(300 \mathrm{MHz}, \mathrm{CDCl}_{3}\right)$ 


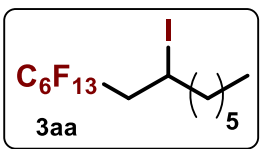

${ }^{13} \mathrm{C}$ NMR $\left(75 \mathrm{MHz}, \mathrm{CDCl}_{3}\right.$ )

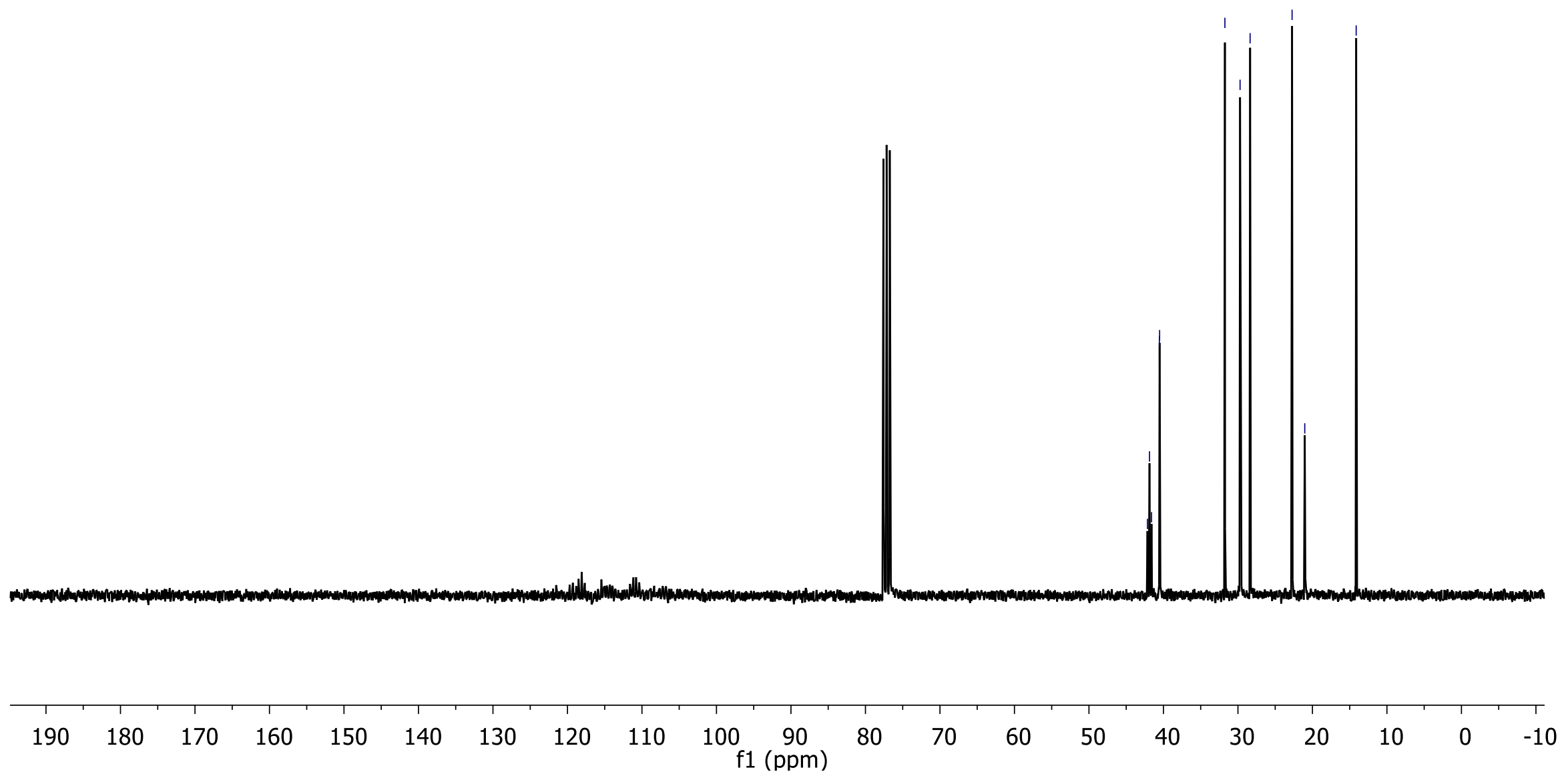




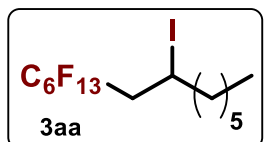

${ }^{19} \mathrm{~F}$ NMR $\left(282 \mathrm{MHz}, \mathrm{CDCl}_{3}\right)$
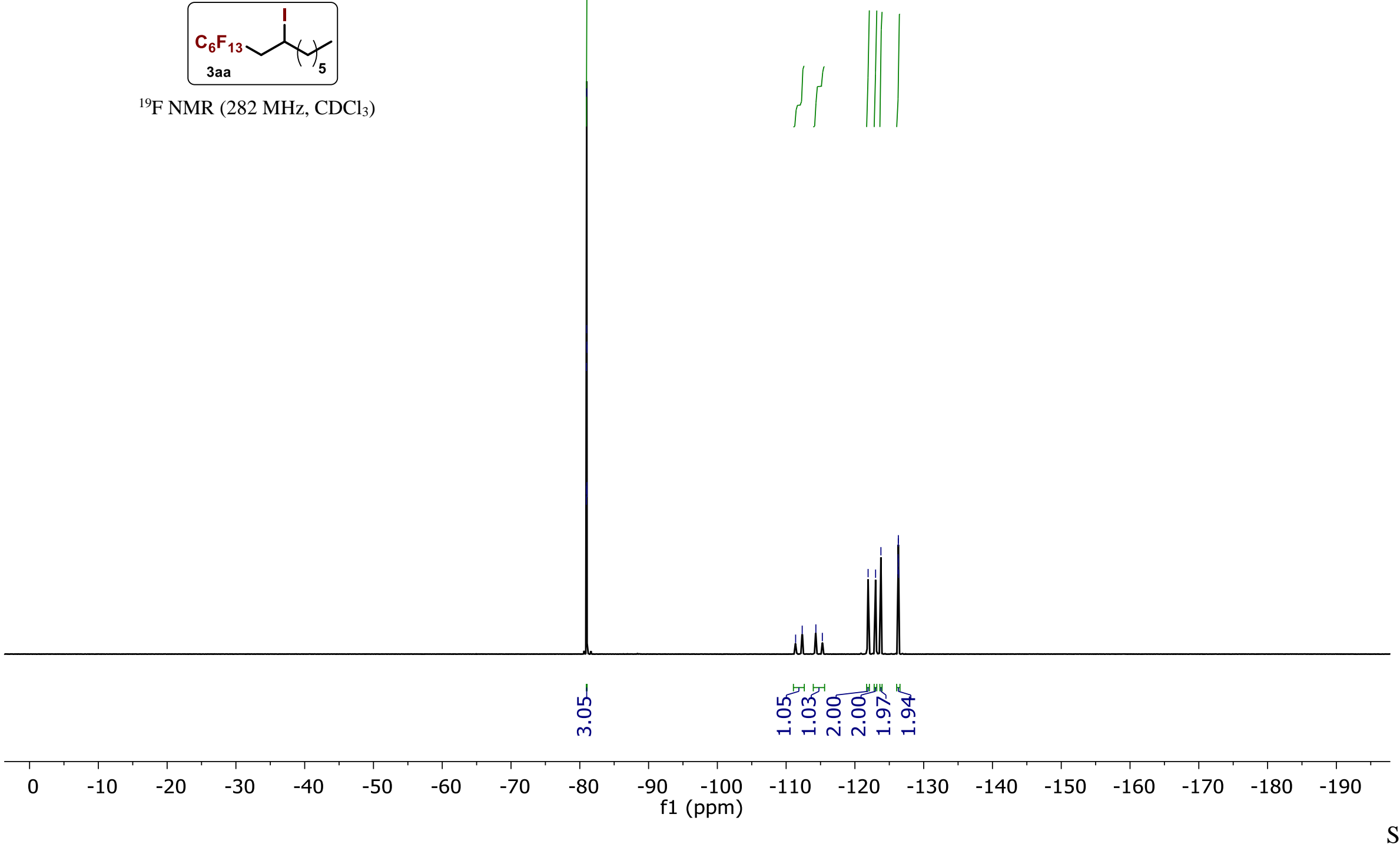


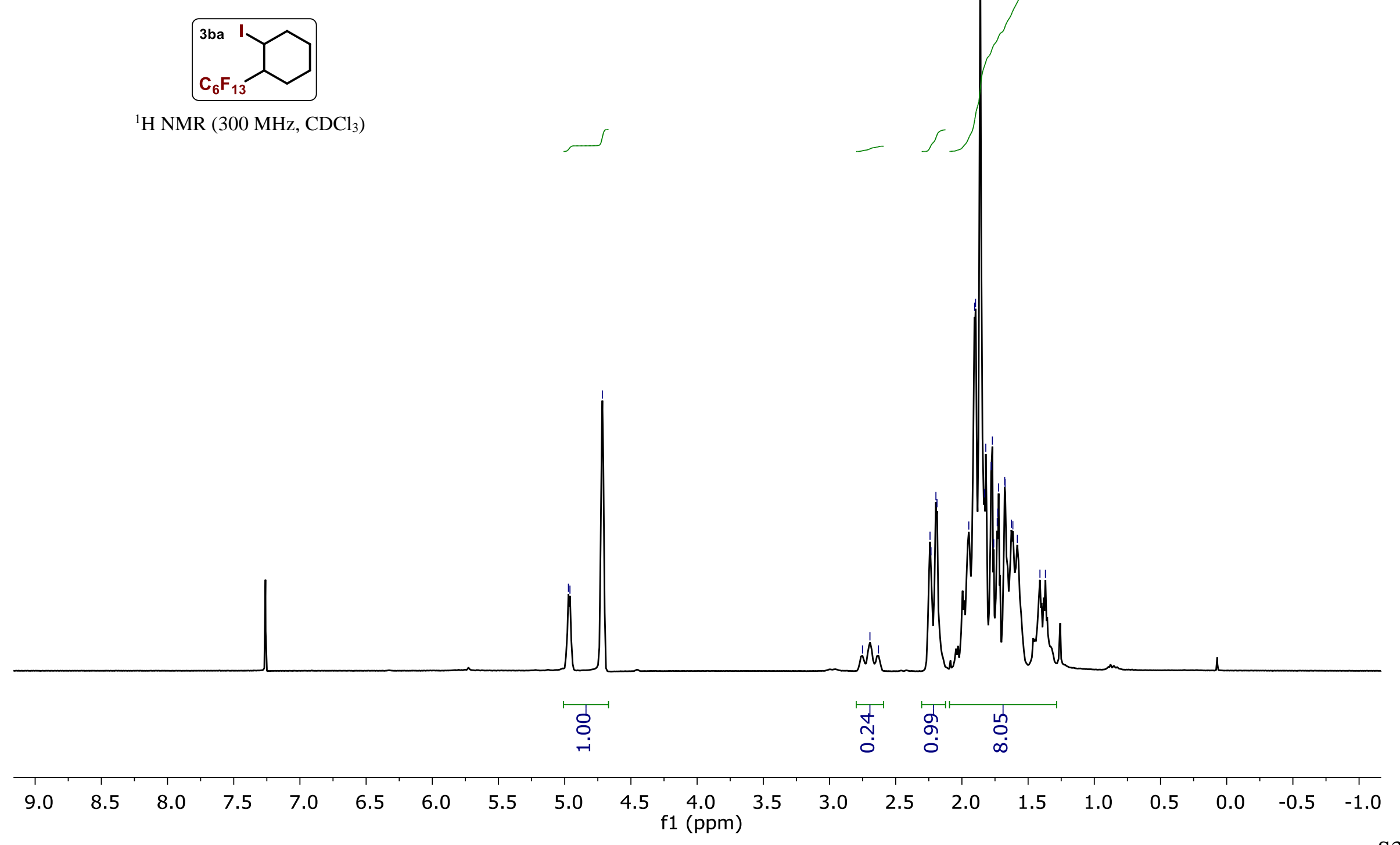

${ }^{1} \mathrm{H} \mathrm{NMR}\left(300 \mathrm{MHz}, \mathrm{CDCl}_{3}\right)$

Nin Nini 


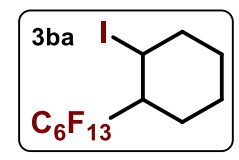

${ }^{13} \mathrm{C} \mathrm{NMR}\left(75 \mathrm{MHz}, \mathrm{CDCl}_{3}\right)$

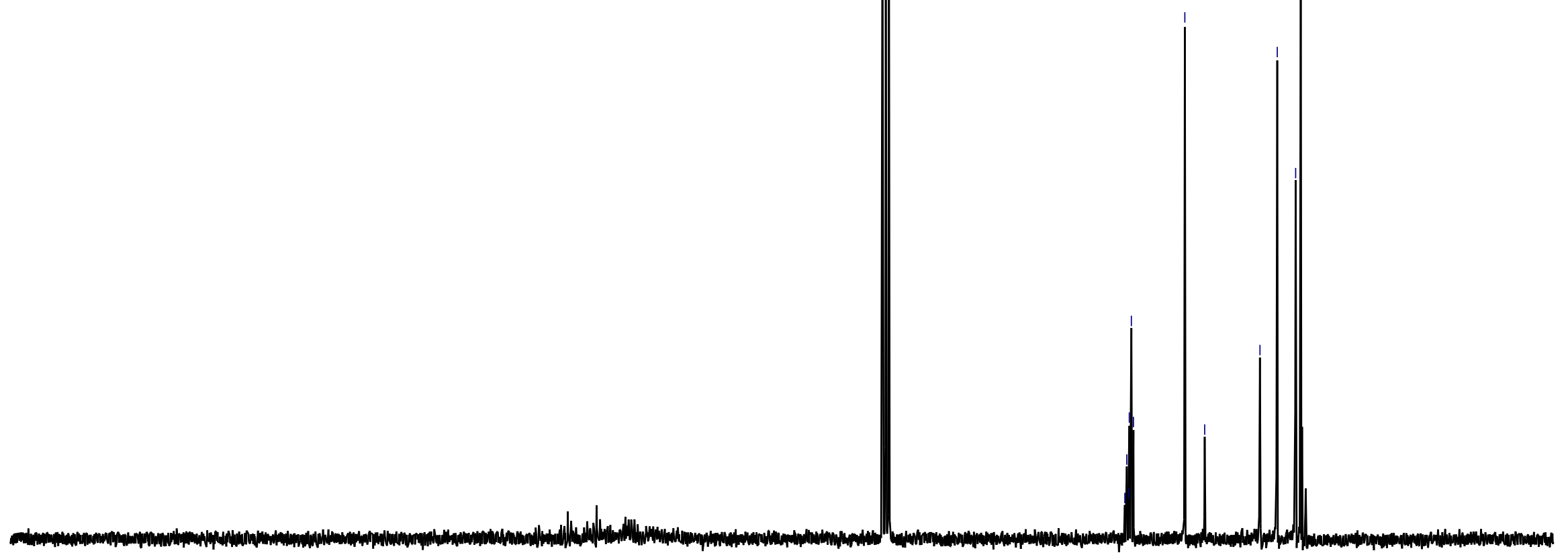

$\begin{array}{lllllllllllllllllllll}190 & 180 & 170 & 160 & 150 & 140 & 130 & 120 & 110 & 100 \underset{\mathrm{f} 1(\mathrm{ppm})}{90} & 80 & 70 & 60 & 50 & 40 & 30 & 20 & 10 & 0 & -10\end{array}$



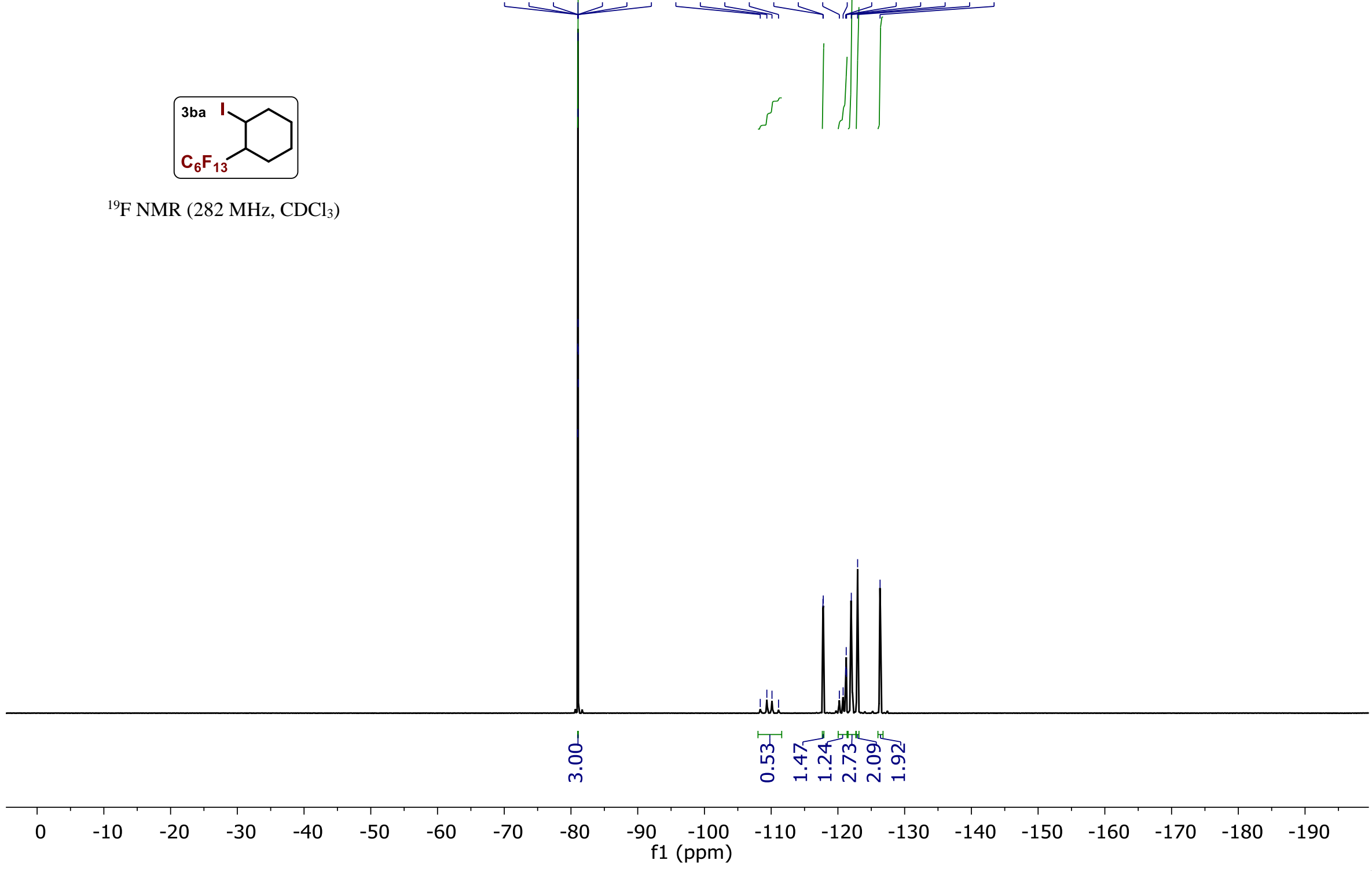

${ }^{19} \mathrm{~F}$ NMR (282 MHz, $\mathrm{CDCl}_{3}$ ) 


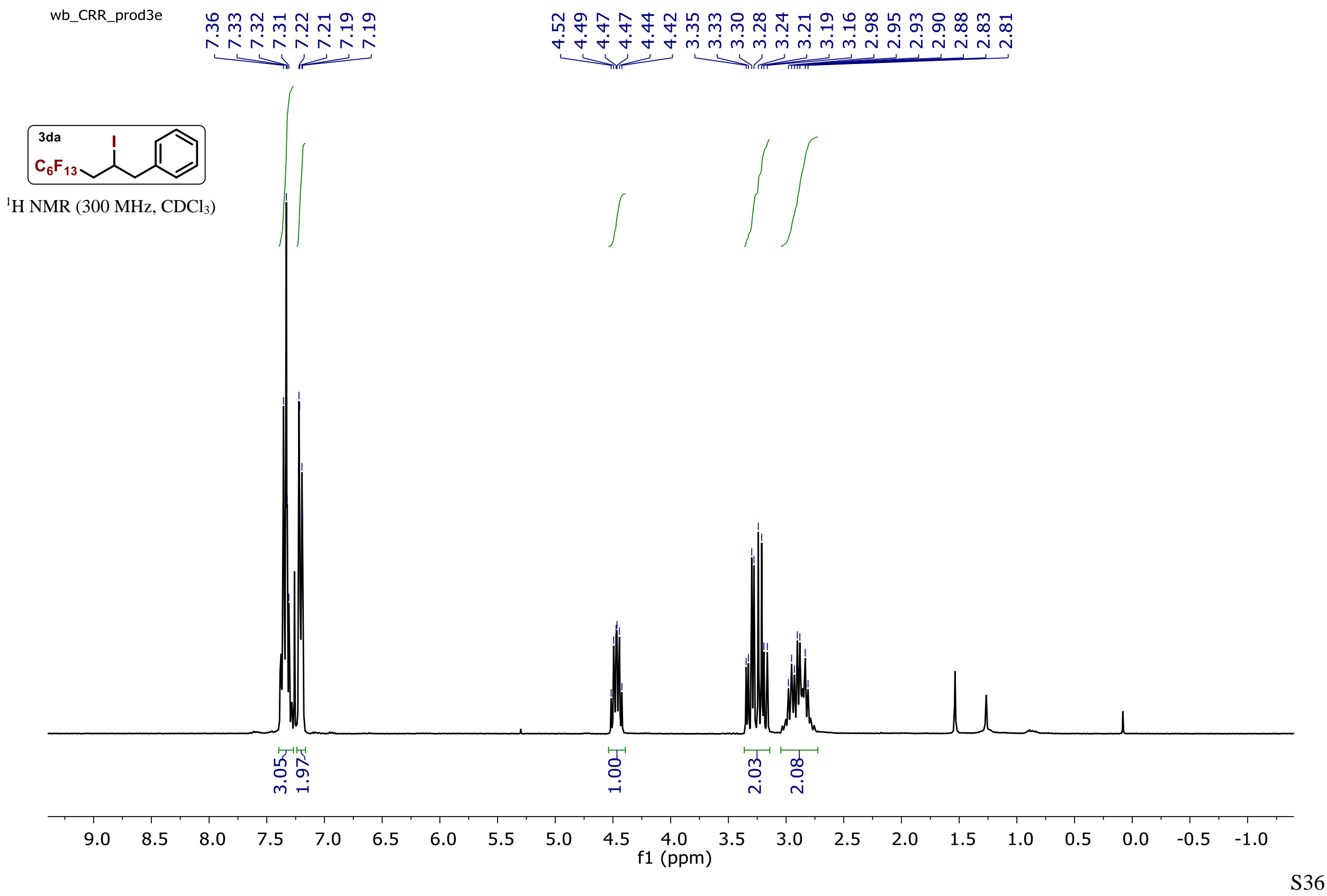




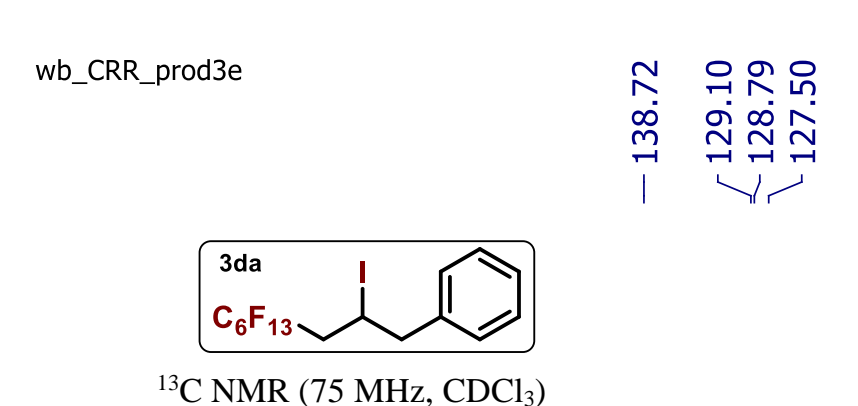

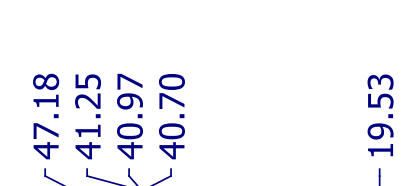

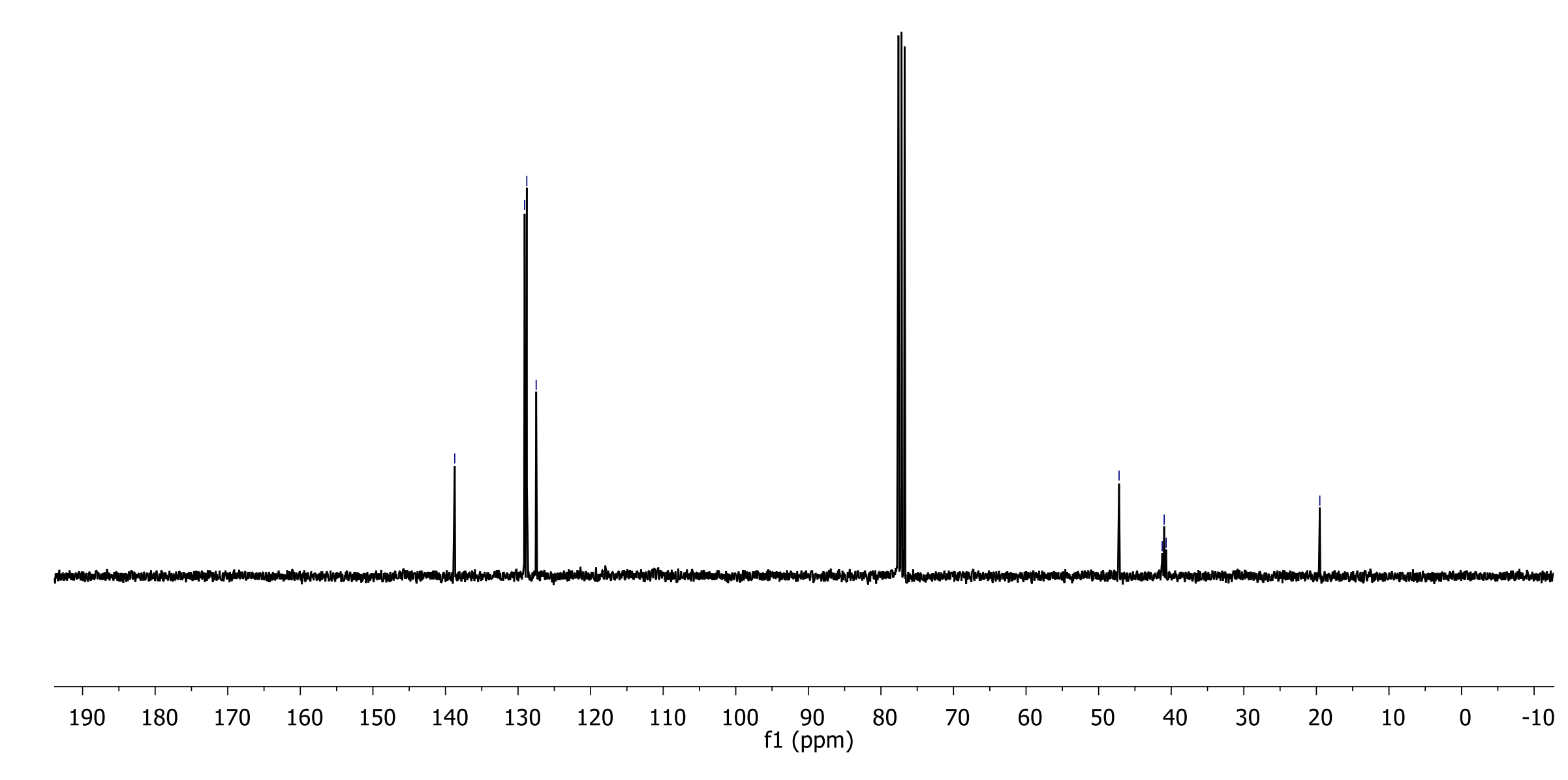




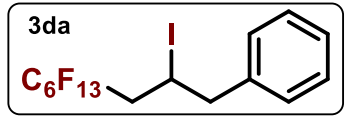

${ }^{19} \mathrm{~F}$ NMR $\left(282 \mathrm{MHz}, \mathrm{CDCl}_{3}\right)$
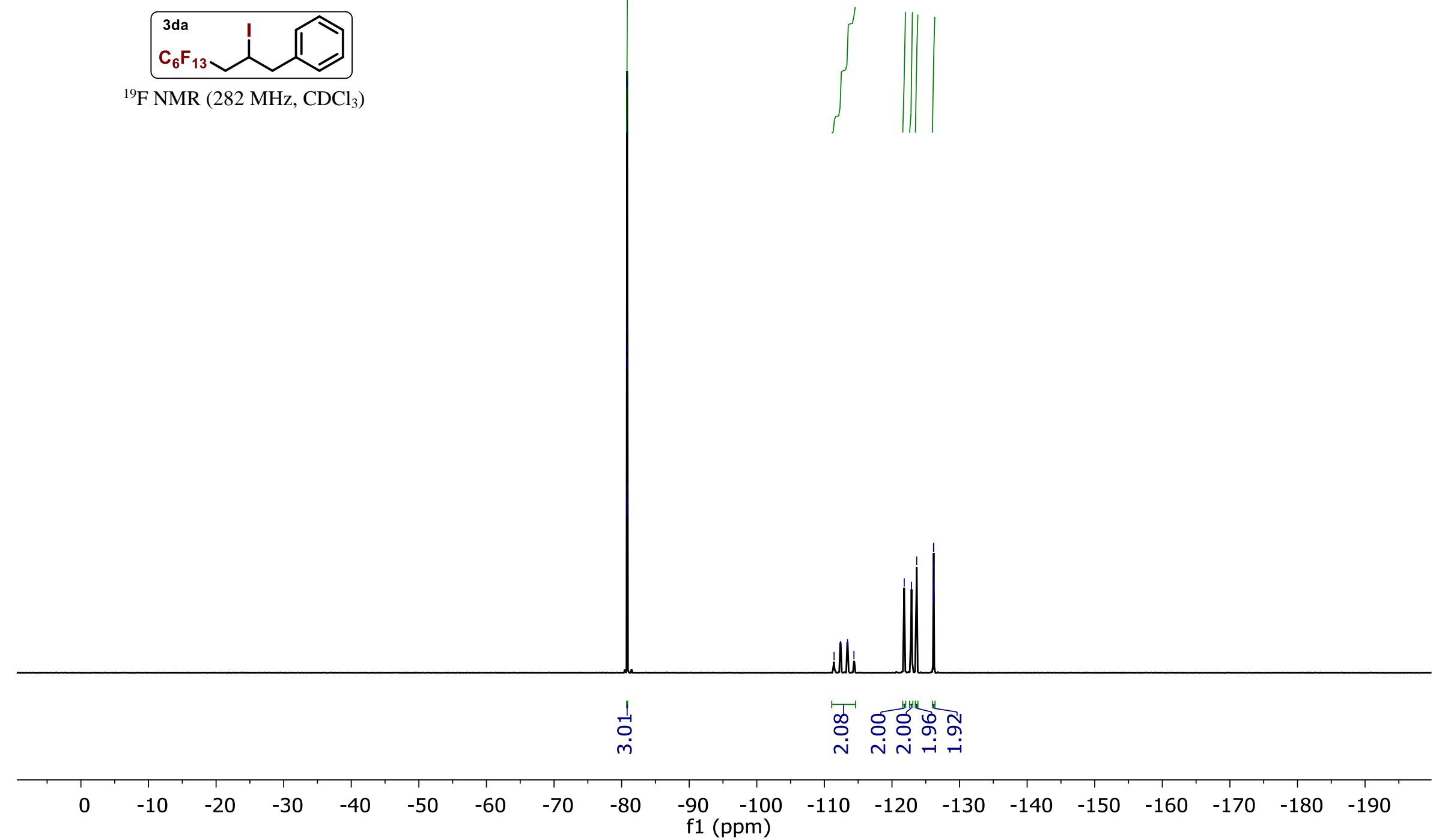


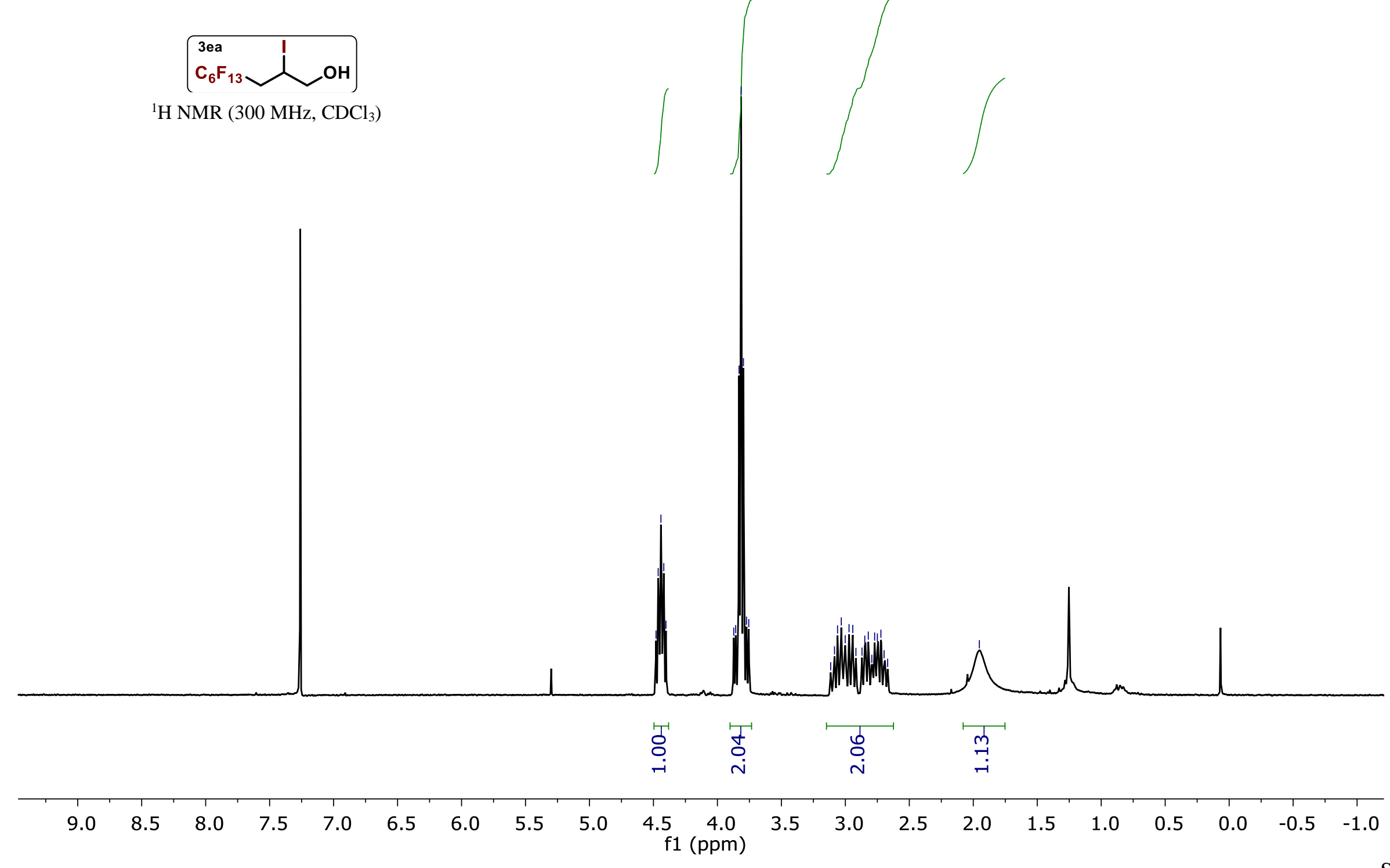




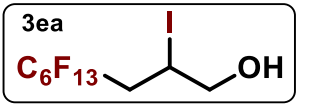

${ }^{13} \mathrm{C}$ NMR (75 MHz, $\mathrm{CDCl}_{3}$ )

$\begin{array}{lllllllllllllllllllllll}190 & 180 & 170 & 160 & 150 & 140 & 130 & 120 & 110 & 100 & \underset{f 1}{9(\mathrm{ppm})} & 80 & 70 & 60 & 50 & 40 & 30 & 20 & 10 & 0 & -10\end{array}$




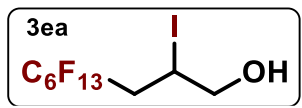

${ }^{19} \mathrm{~F}$ NMR $\left(282 \mathrm{MHz}, \mathrm{CDCl}_{3}\right)$
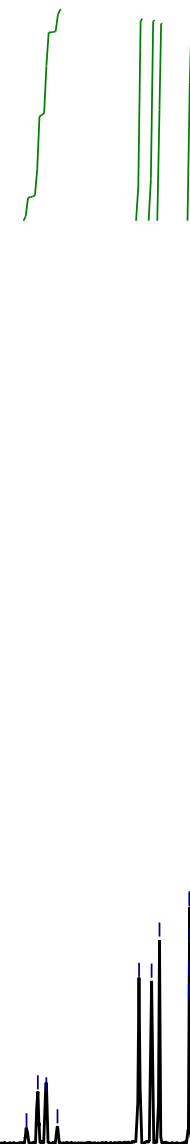

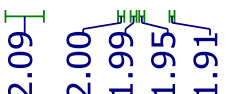

\begin{tabular}{|c|c|c|c|c|c|c|c|c|c|c|c|c|c|c|c|c|c|c|c|}
\hline 0 & -10 & -20 & -30 & -40 & -50 & -60 & -70 & -80 & $\begin{array}{r}-90 \\
f 1\end{array}$ & $\begin{array}{c}-100 \\
(\mathrm{ppm})\end{array}$ & -110 & -120 & -130 & -140 & -150 & -160 & -170 & -180 & -190 \\
\hline
\end{tabular}




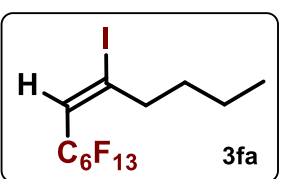

${ }^{1} \mathrm{H}$ NMR $\left(300 \mathrm{MHz}, \mathrm{CDCl}_{3}\right)$
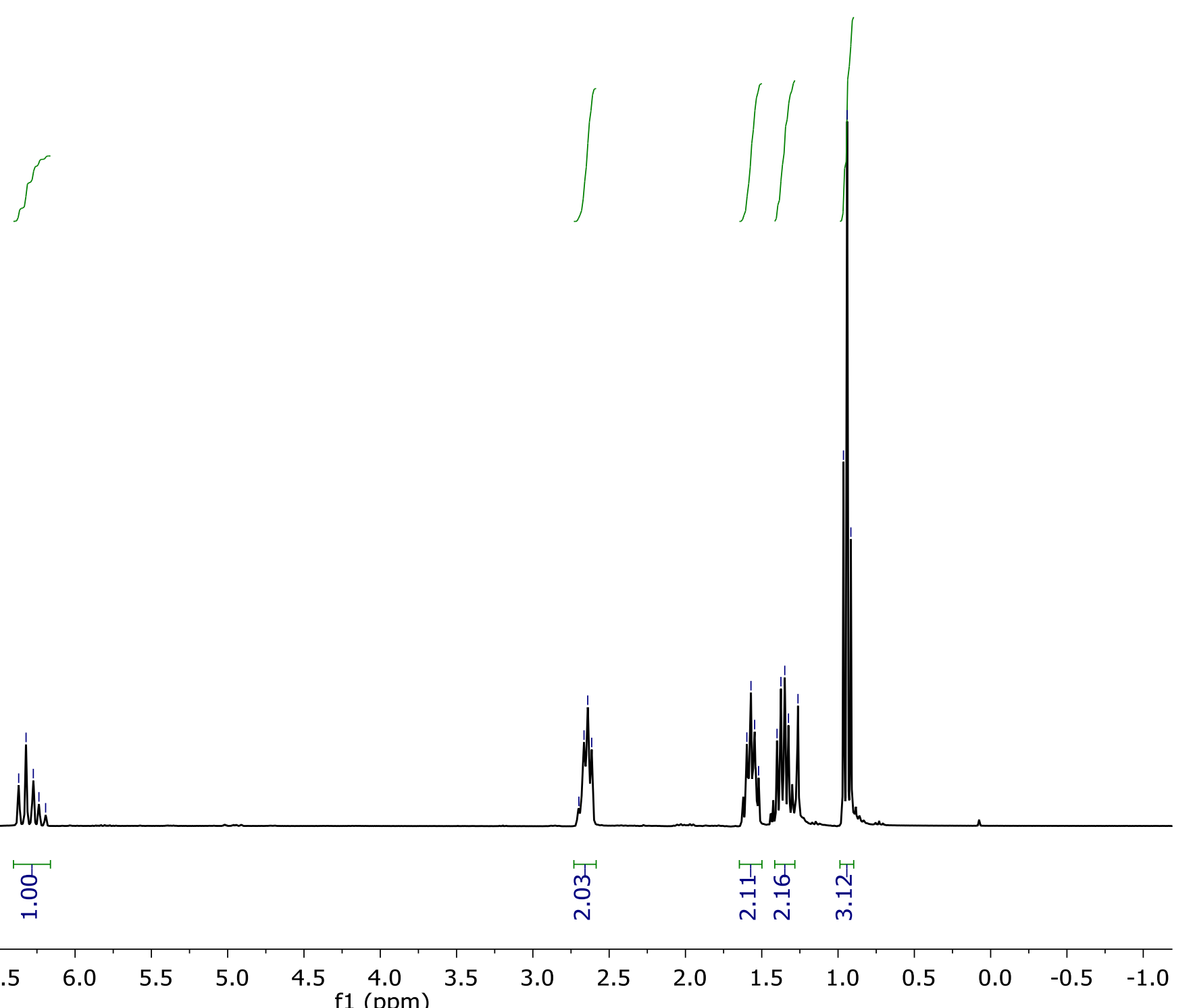


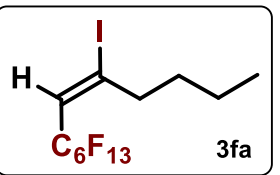

${ }^{13} \mathrm{C}$ NMR $\left(75 \mathrm{MHz}, \mathrm{CDCl}_{3}\right.$ )

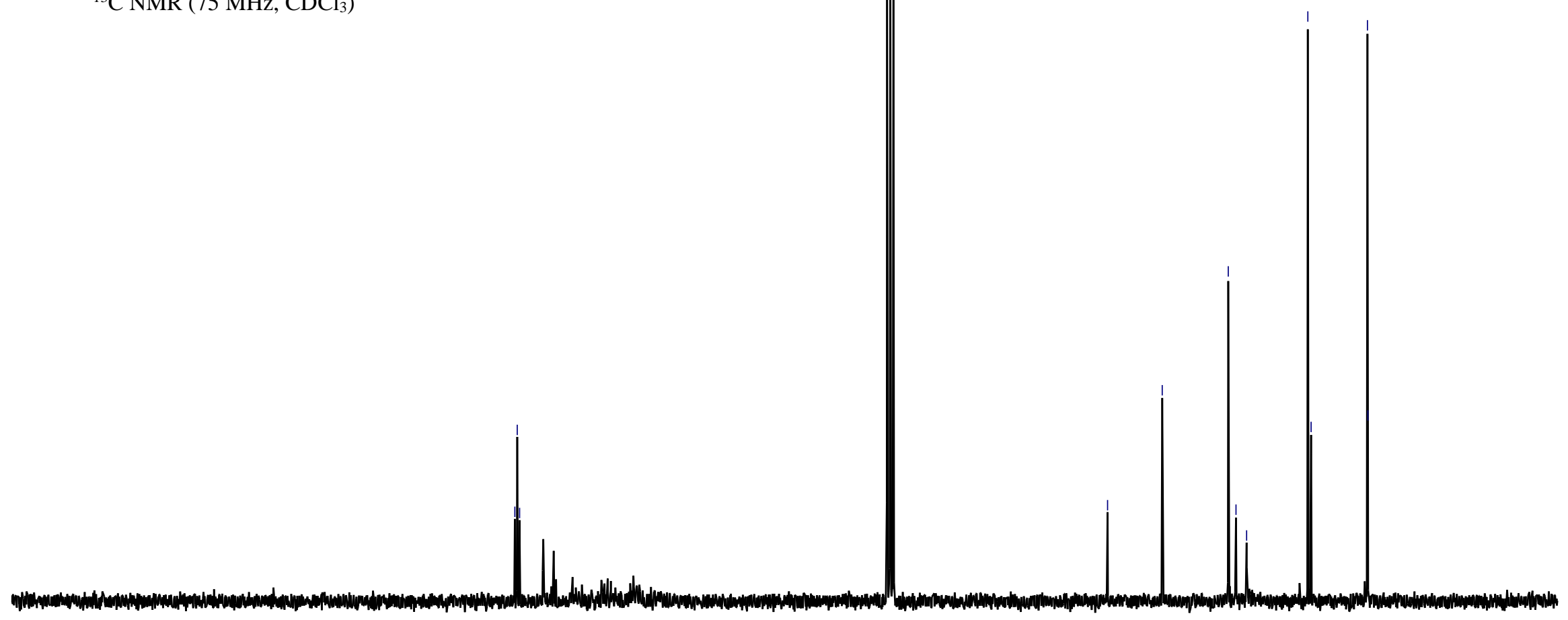

$\begin{array}{lllllllllllllllllllll}190 & 180 & 170 & 160 & 150 & 140 & 130 & 120 & 110 & 100 \underset{\mathrm{f} 1(\mathrm{ppm})}{90} & 80 & 70 & 60 & 50 & 40 & 30 & 20 & 10 & 0 & -10\end{array}$




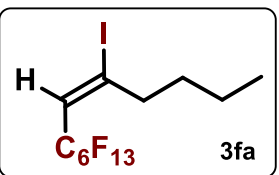

${ }^{19} \mathrm{~F}$ NMR $\left(282 \mathrm{MHz}, \mathrm{CDCl}_{3}\right)$
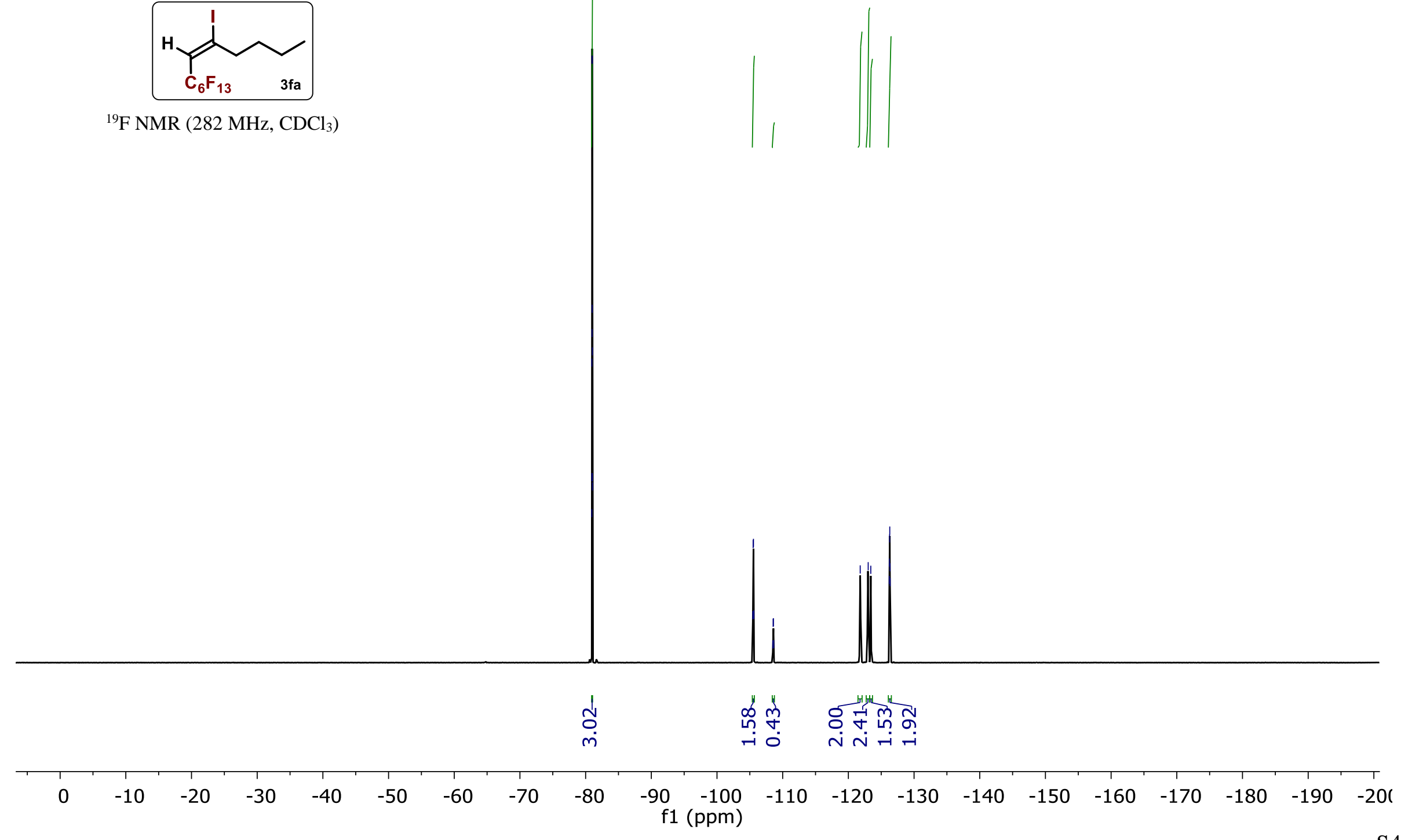


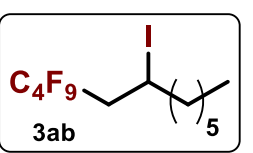

${ }^{1} \mathrm{H}$ NMR $\left(300 \mathrm{MHz}, \mathrm{CDCl}_{3}\right)$
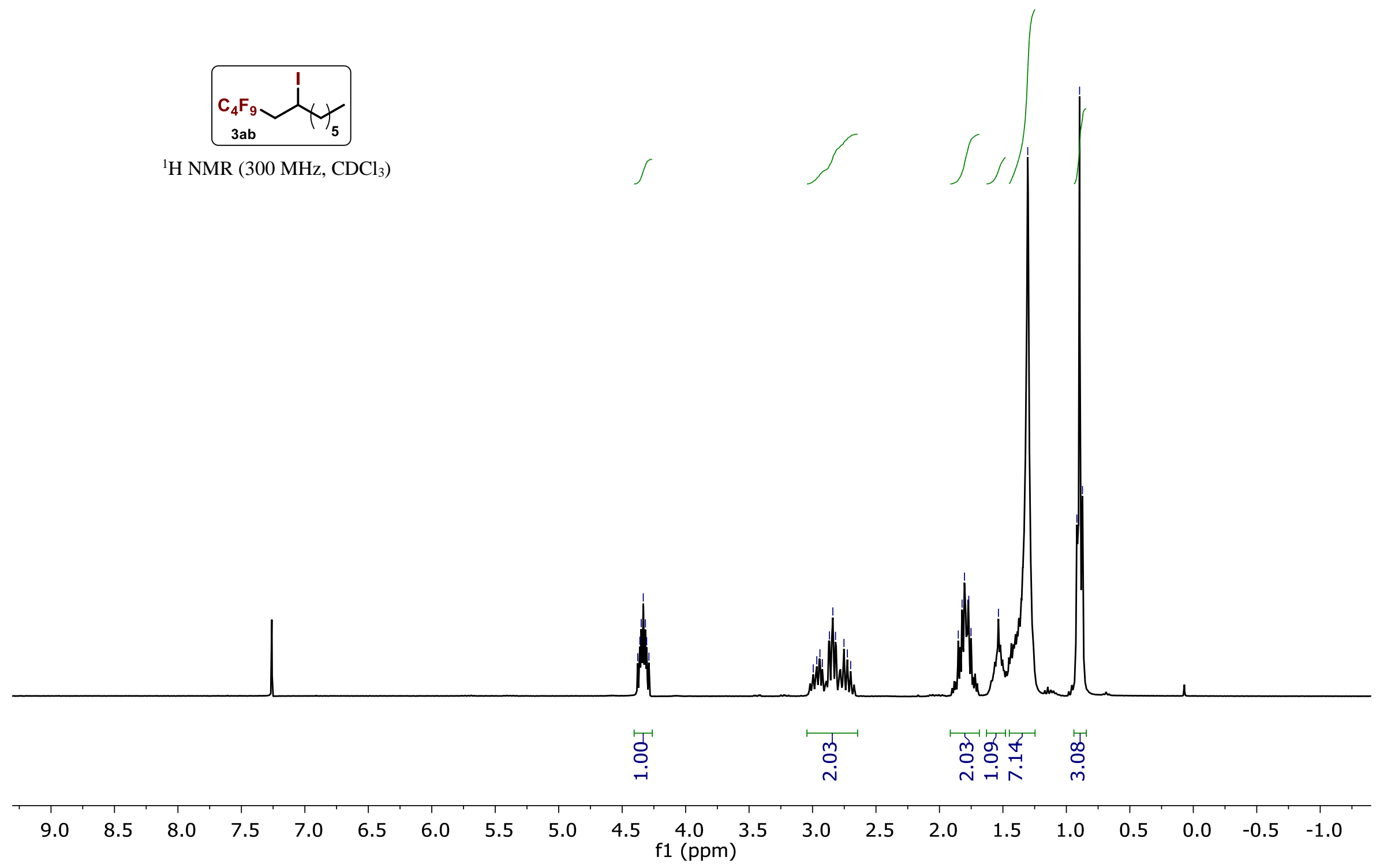


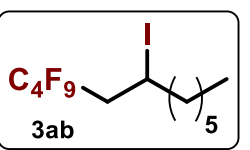

${ }^{13} \mathrm{C}$ NMR $\left(75 \mathrm{MHz}, \mathrm{CDCl}_{3}\right)$

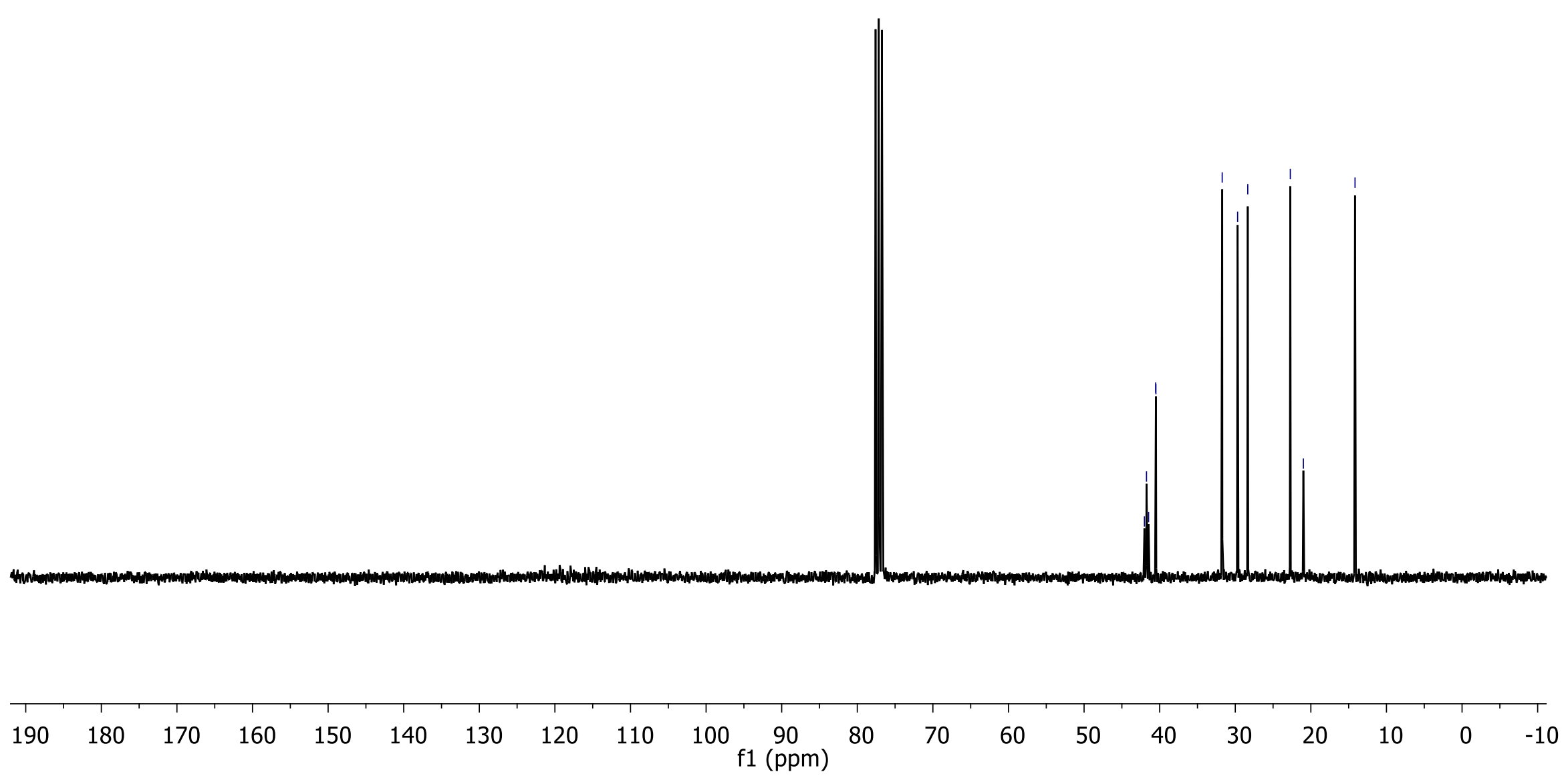




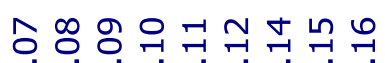
क्ष

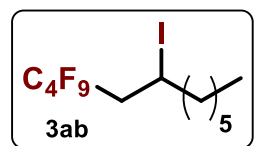

${ }^{19} \mathrm{~F}$ NMR (282 MHz, $\mathrm{CDCl}_{3}$ )

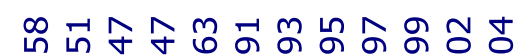

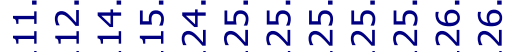

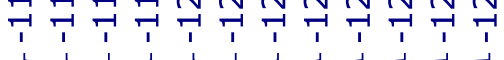

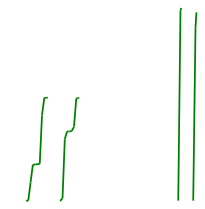

ili

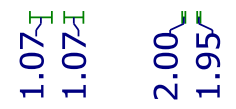

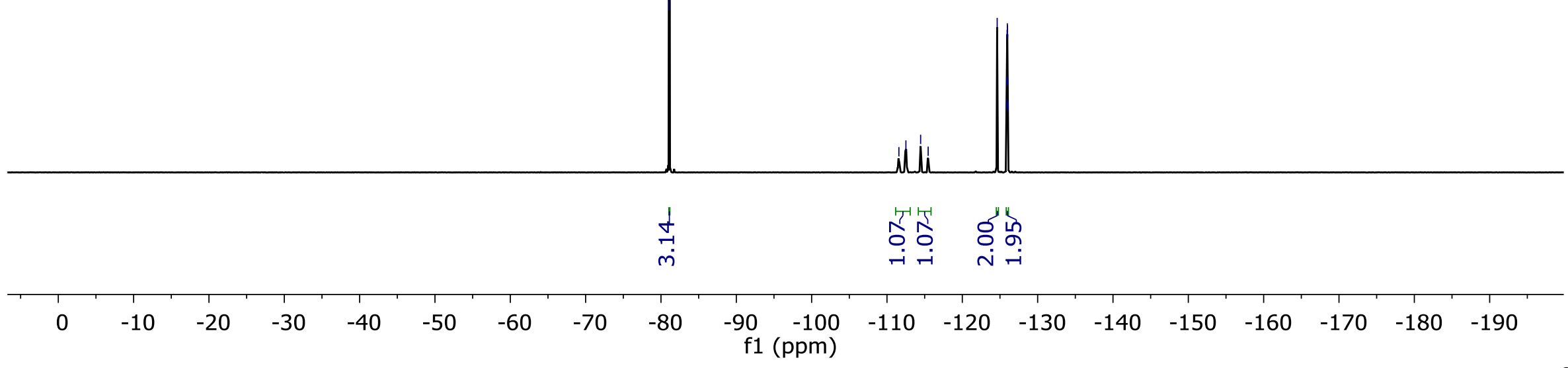




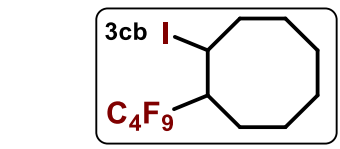

${ }^{1} \mathrm{H}$ NMR (300 MHz, $\mathrm{CDCl}_{3}$ )
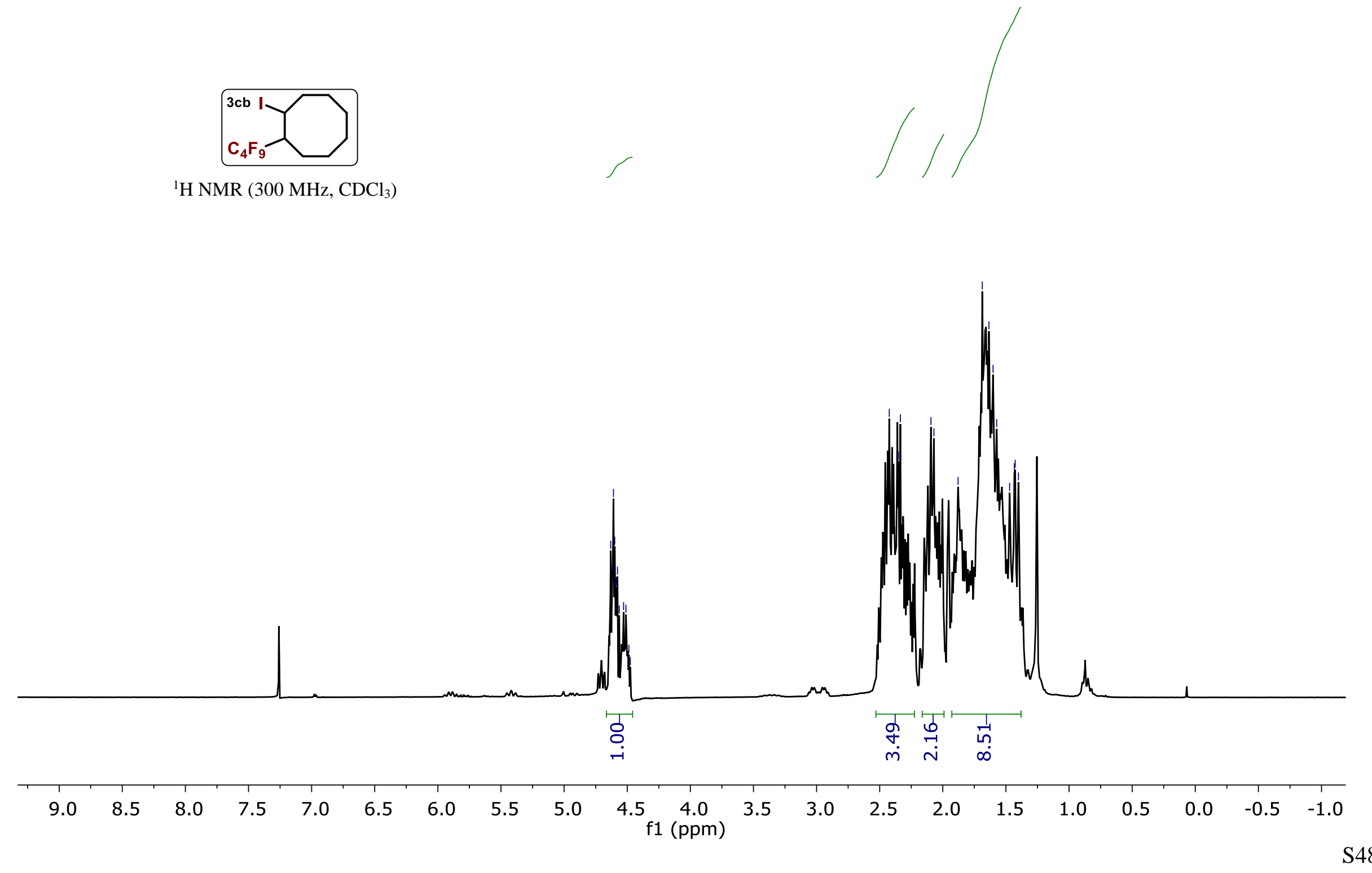


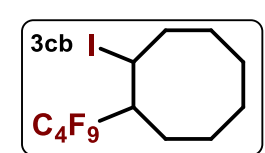

${ }^{13} \mathrm{C}$ NMR $\left(75 \mathrm{MHz}, \mathrm{CDCl}_{3}\right)$

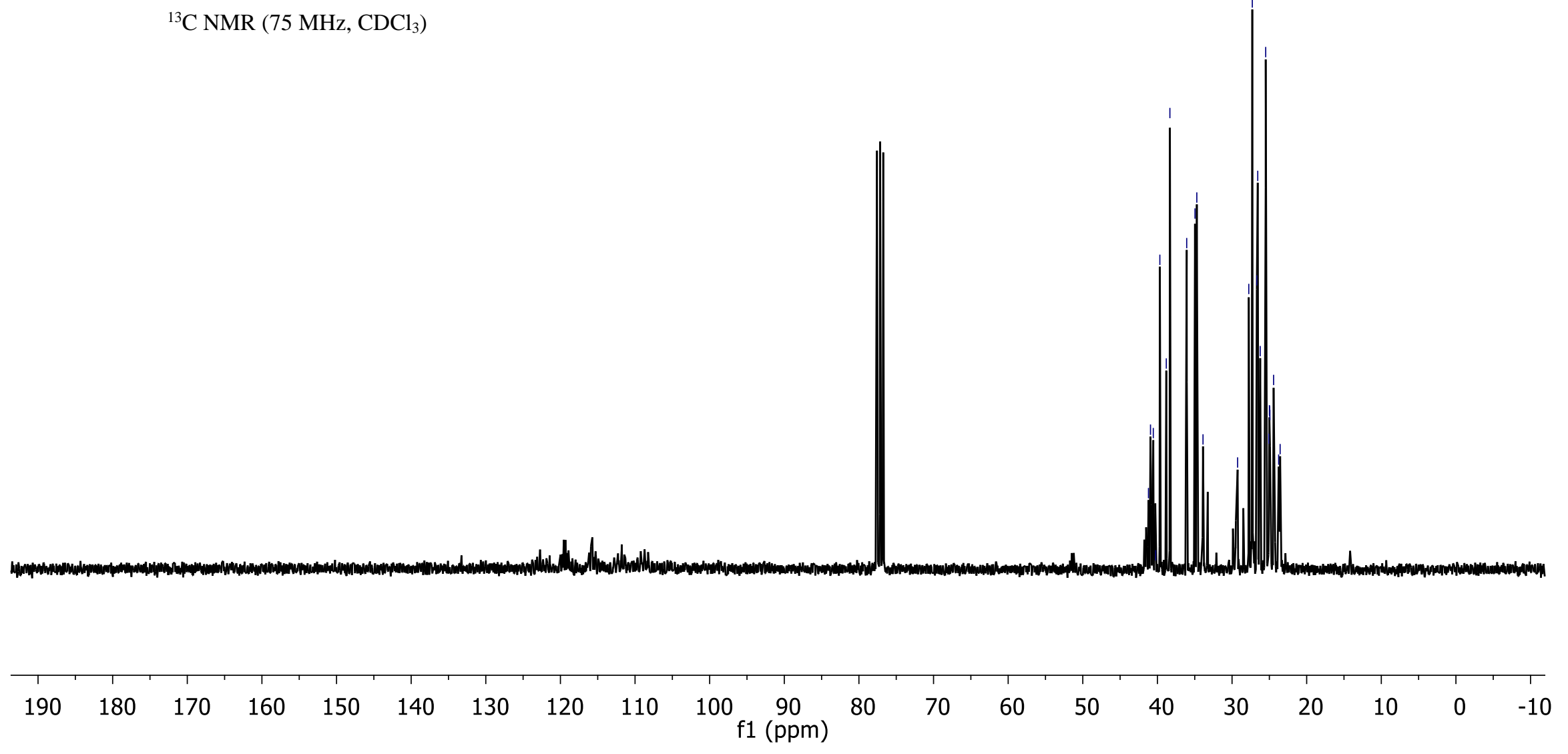




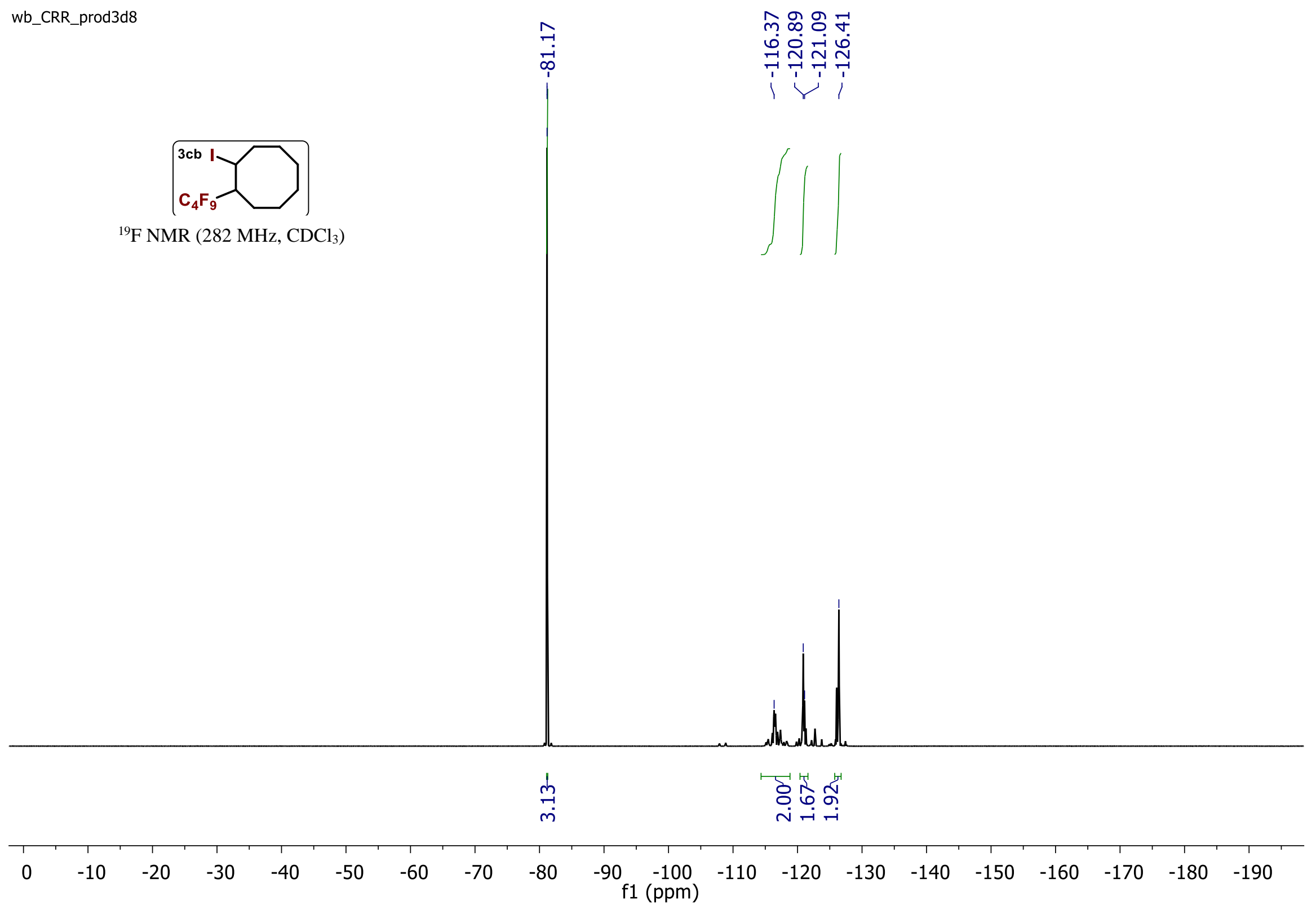




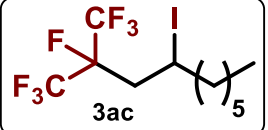

${ }^{1} \mathrm{H}$ NMR $\left(300 \mathrm{MHz}, \mathrm{CDCl}_{3}\right)$
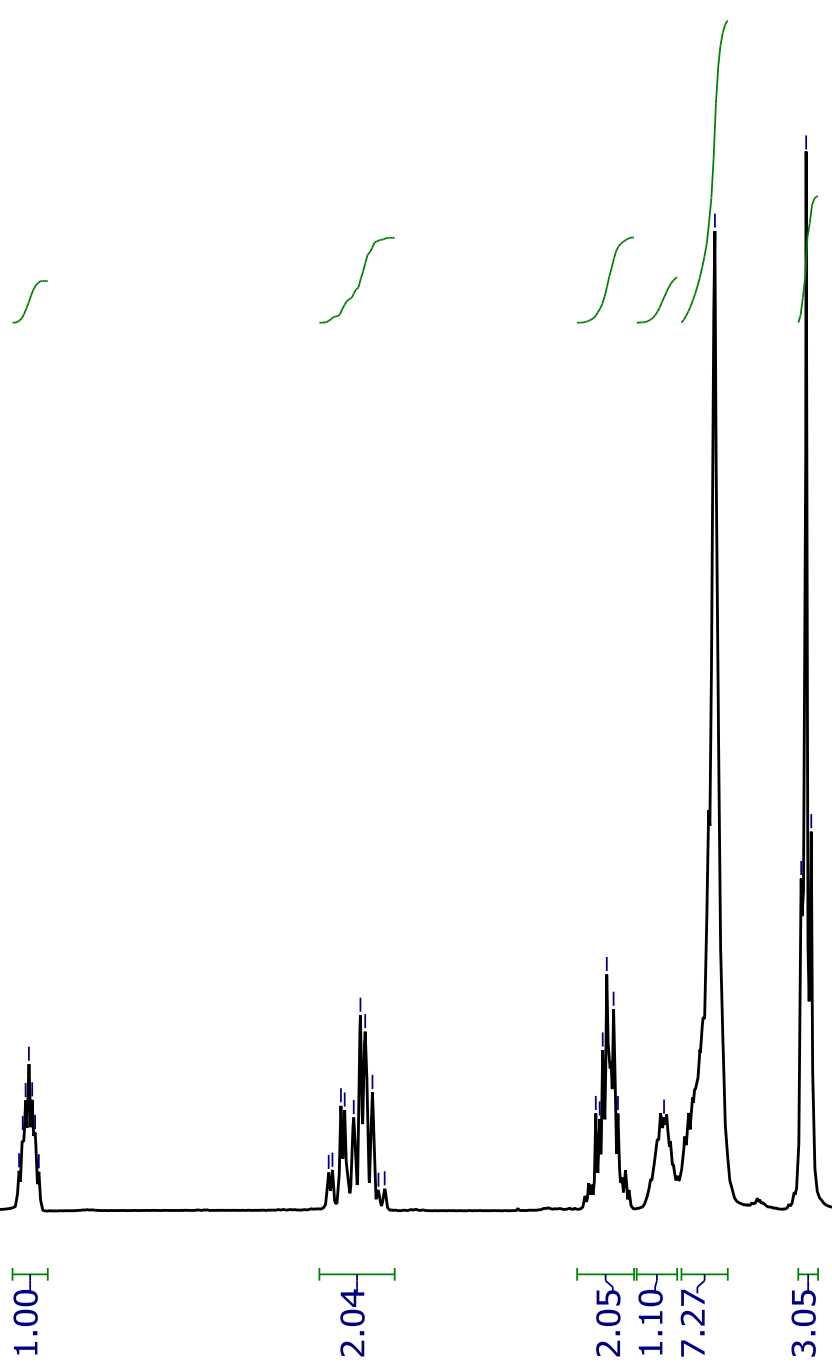

9.0

8.0

7.5

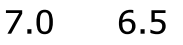

6.0

5.5

5.0

$4.5 \underset{f 1(p p m)}{4.0} 3.5$

$3.0 \quad 2.5$

$1.0 \quad 0.5$ 


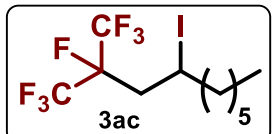

${ }^{13} \mathrm{C}$ NMR $\left(75 \mathrm{MHz}, \mathrm{CDCl}_{3}\right)$

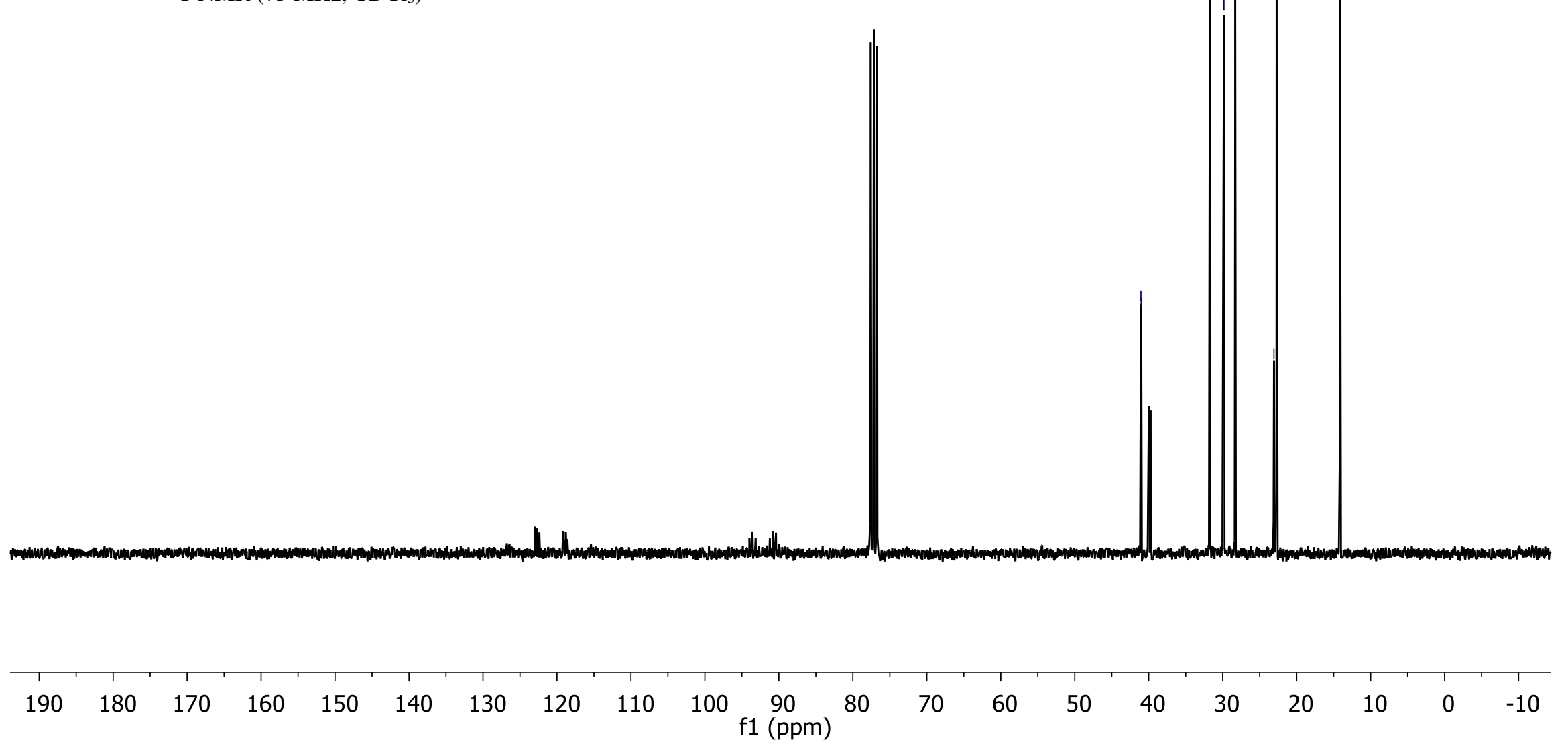




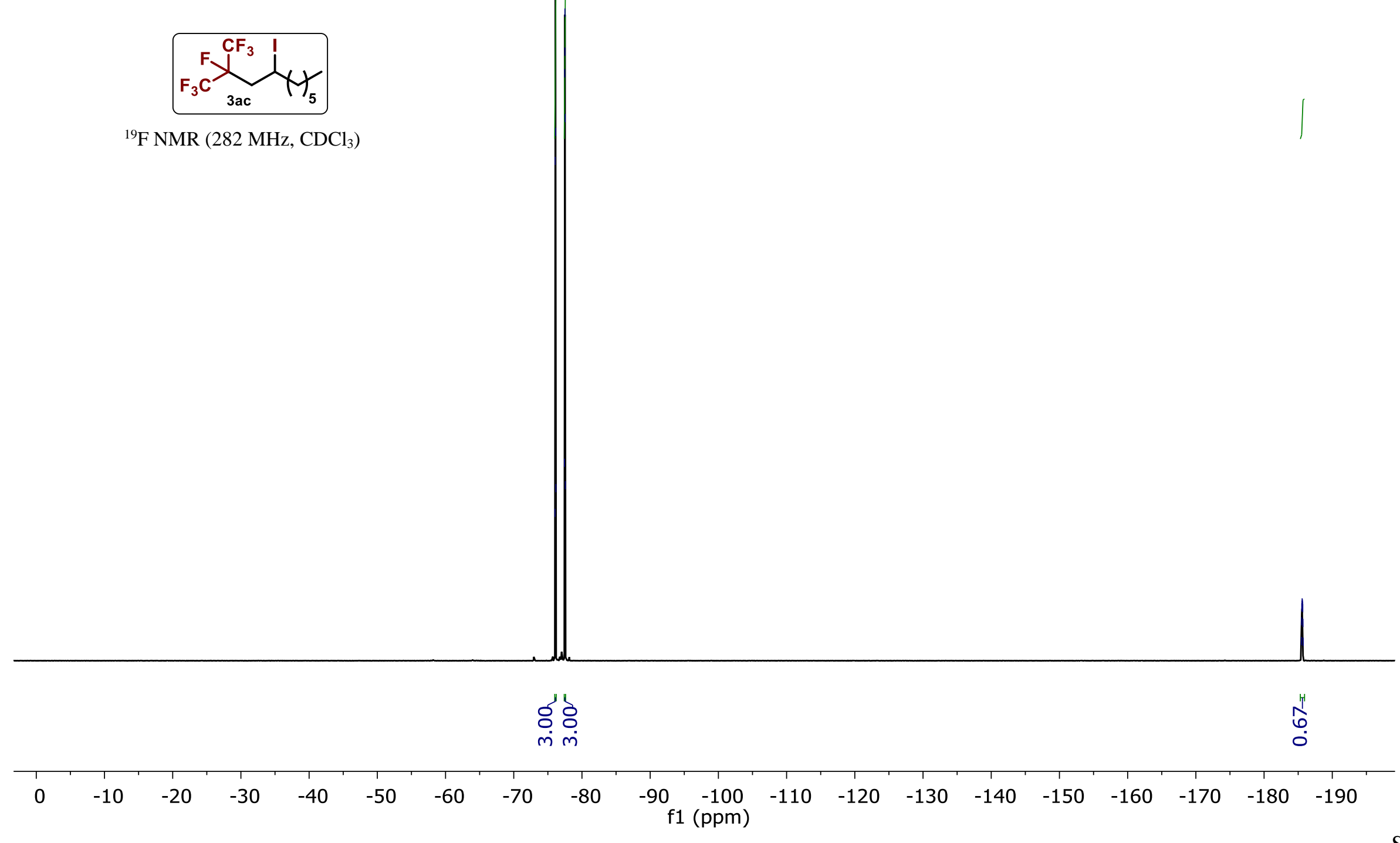

${ }^{19} \mathrm{~F}$ NMR $\left(282 \mathrm{MHz}, \mathrm{CDCl}_{3}\right)$

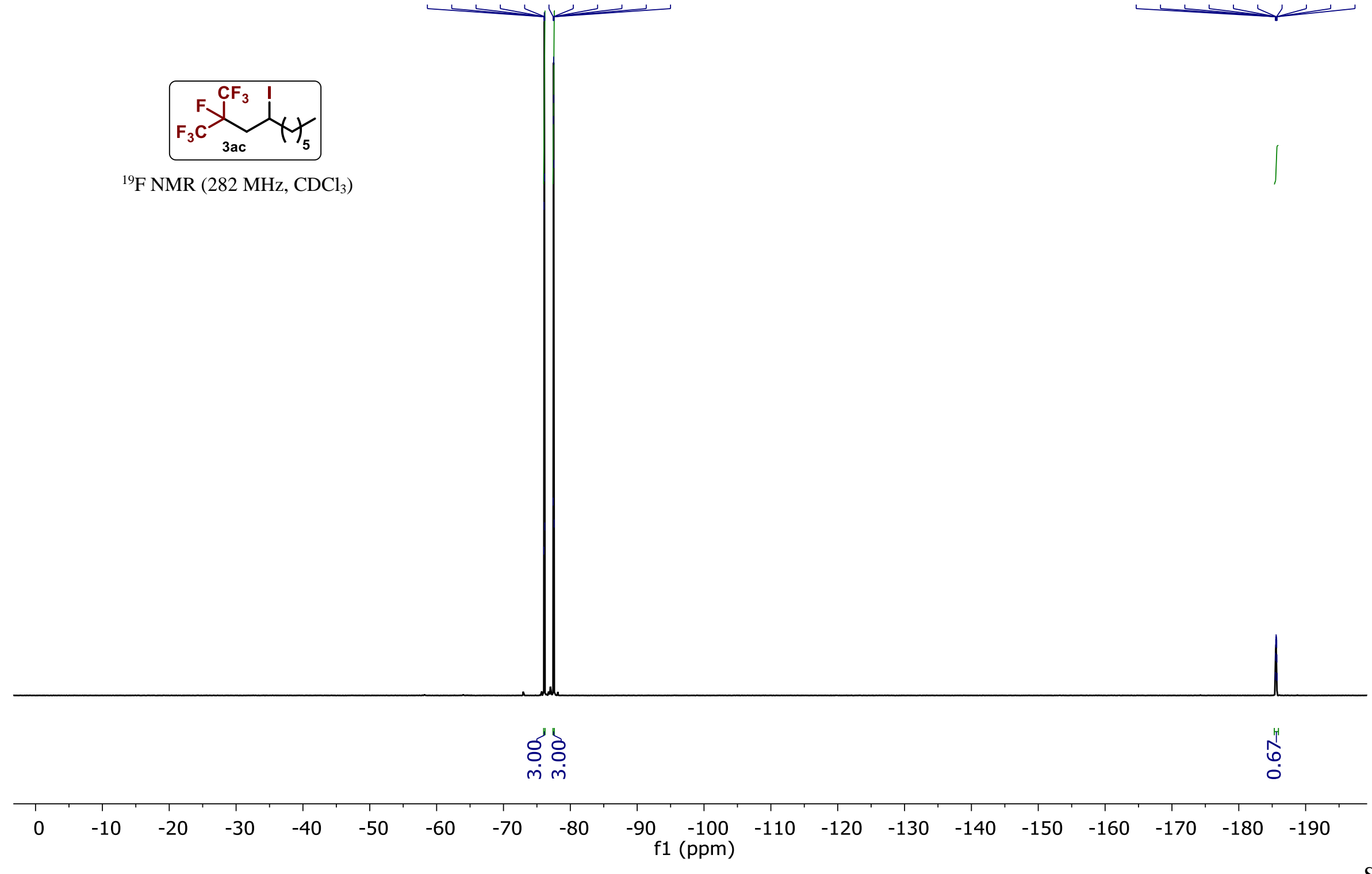

I 1 , 


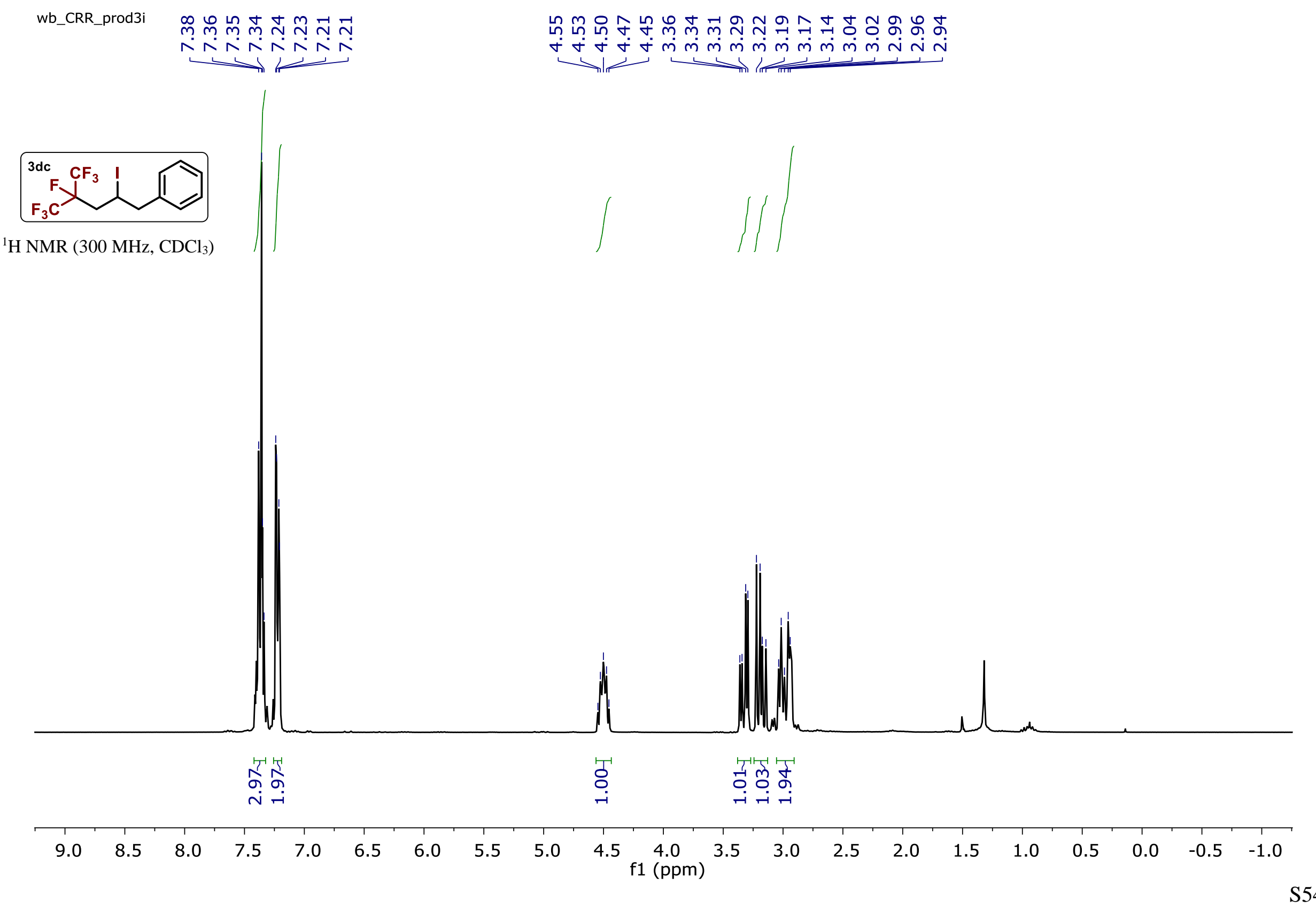




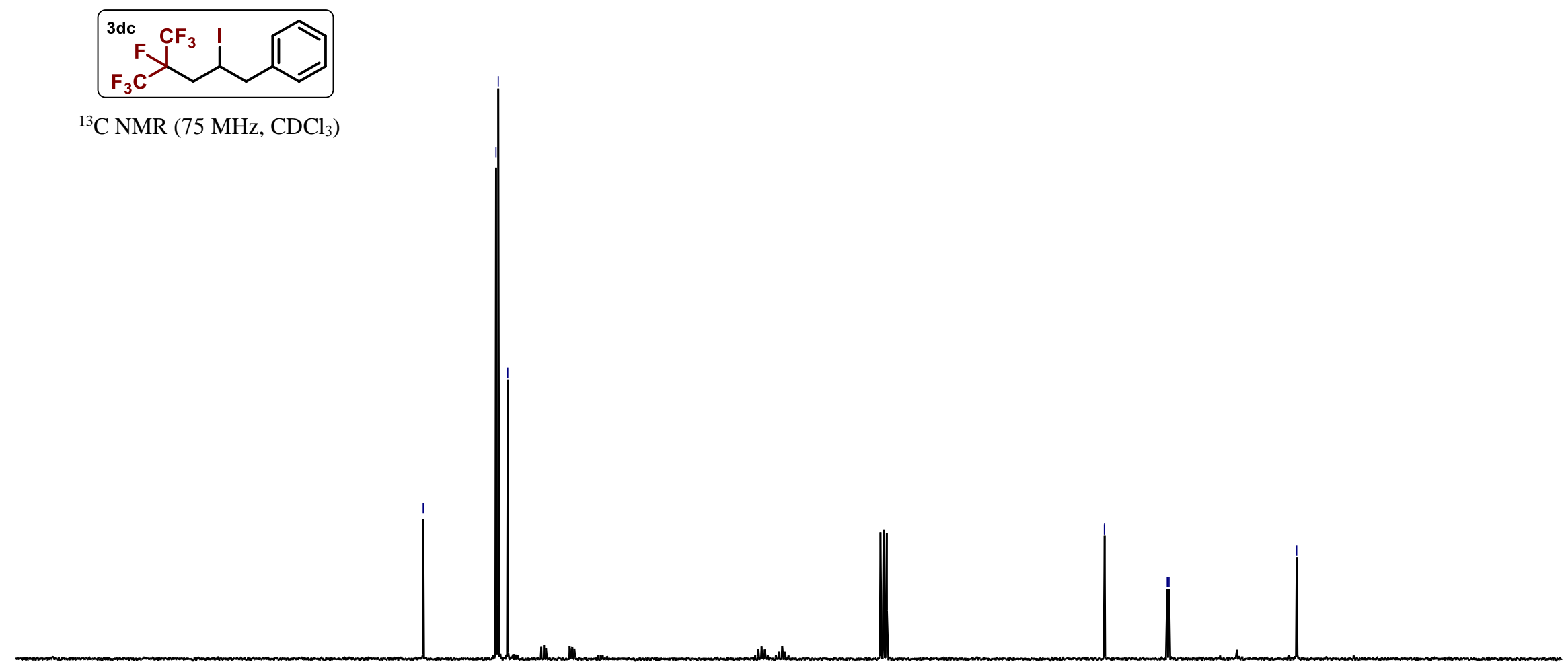

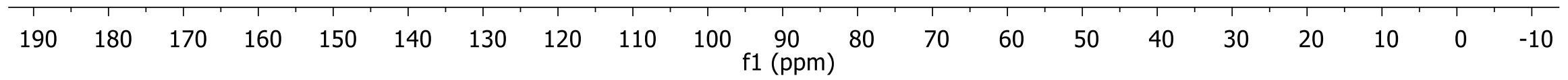




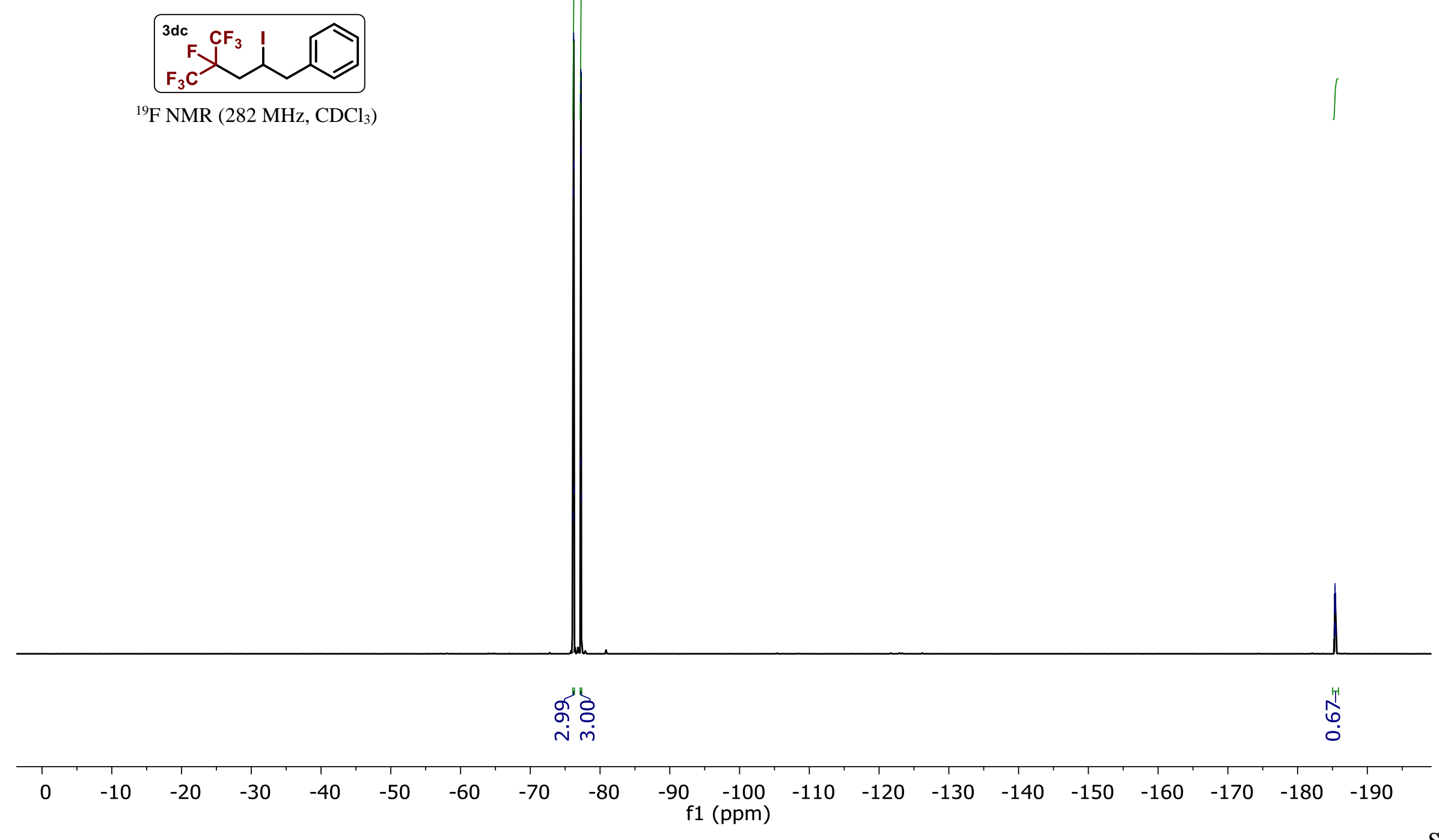

${ }^{19} \mathrm{~F}$ NMR $\left(282 \mathrm{MHz}, \mathrm{CDCl}_{3}\right)$

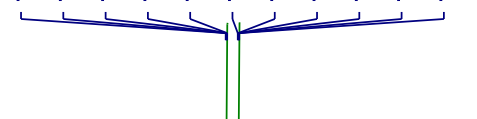




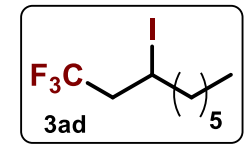

${ }^{1} \mathrm{H} \mathrm{NMR}\left(300 \mathrm{MHz}, \mathrm{CDCl}_{3}\right)$
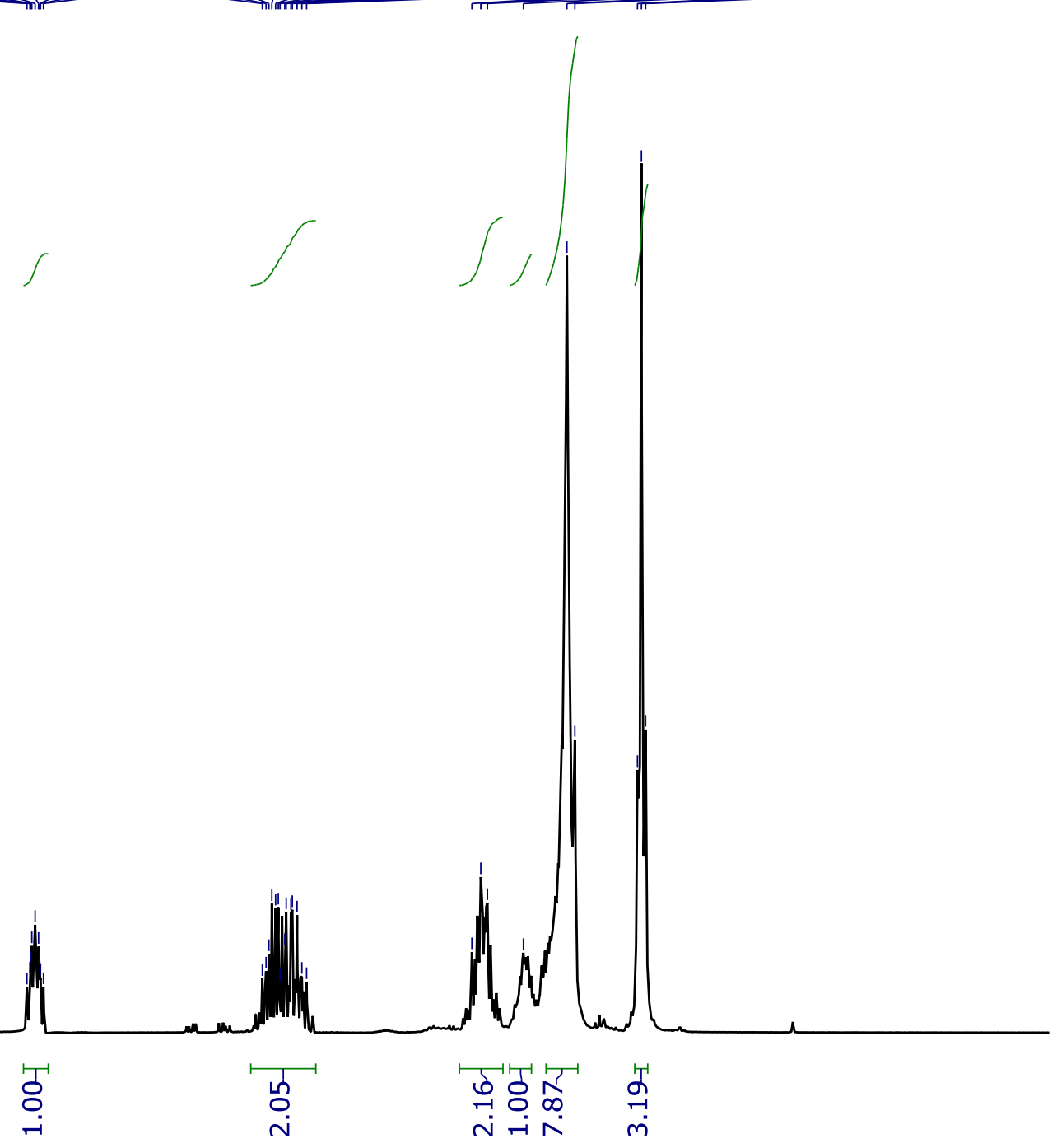

$9.0 \quad 8.5$

$\begin{array}{llll}8.0 & 7.5 & 7.0 & 6.5\end{array}$

6.0

5.5

$4.5 \underset{f 1(\mathrm{ppm})}{4.0} 3.5$

2.5

2.0

1.5

1.0

0.5

$\begin{array}{lll}0.0 & -0.5 & -1.0\end{array}$ 


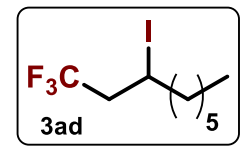

${ }^{13} \mathrm{C} \mathrm{NMR}\left(75 \mathrm{MHz}, \mathrm{CDCl}_{3}\right)$

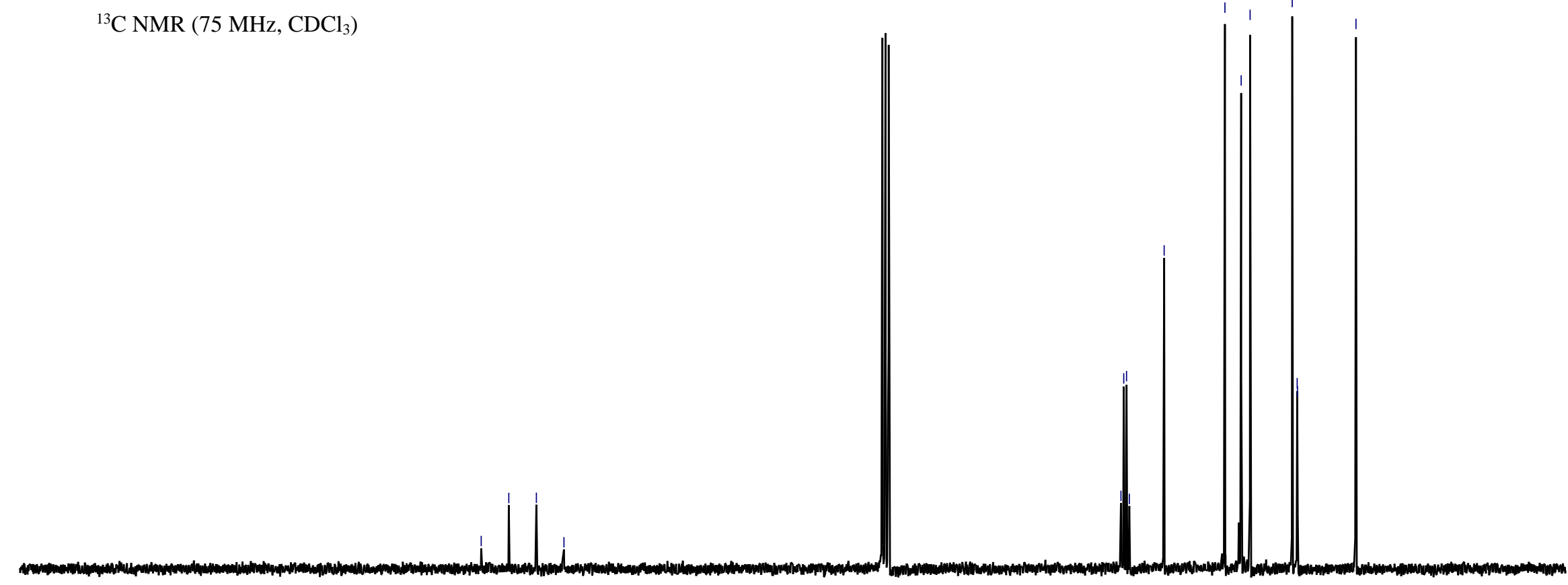

$\begin{array}{llllllllllllllllllll}190 & 180 & 170 & 160 & 150 & 140 & 130 & 120 & 110 & 100 \underset{\mathrm{f} 1(\mathrm{ppm})}{90} & 80 & 70 & 60 & 50 & 40 & 30 & 20 & 10 & 0 & -10\end{array}$




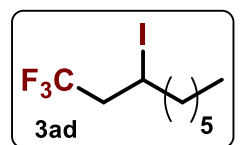

${ }^{19} \mathrm{~F}$ NMR (282 MHz, $\mathrm{CDCl}_{3}$ )

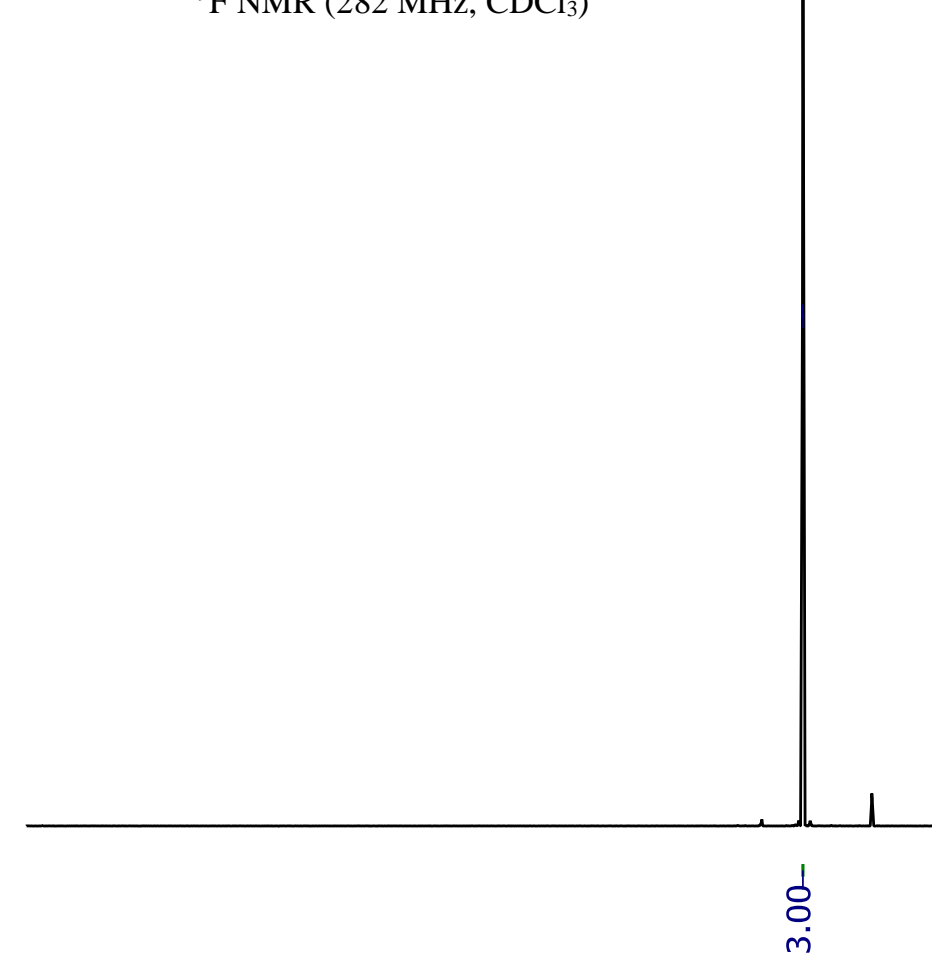

\begin{tabular}{|c|c|c|c|c|c|c|c|c|c|c|c|c|c|c|c|c|c|c|c|}
\hline 0 & -10 & -20 & -30 & -40 & -50 & -60 & -70 & -80 & $-90{ }_{f 1}$ & $\begin{array}{c}-100 \\
(\mathrm{ppm})\end{array}$ & -110 & -120 & -130 & -140 & -150 & -160 & -170 & -180 & -190 \\
\hline
\end{tabular}




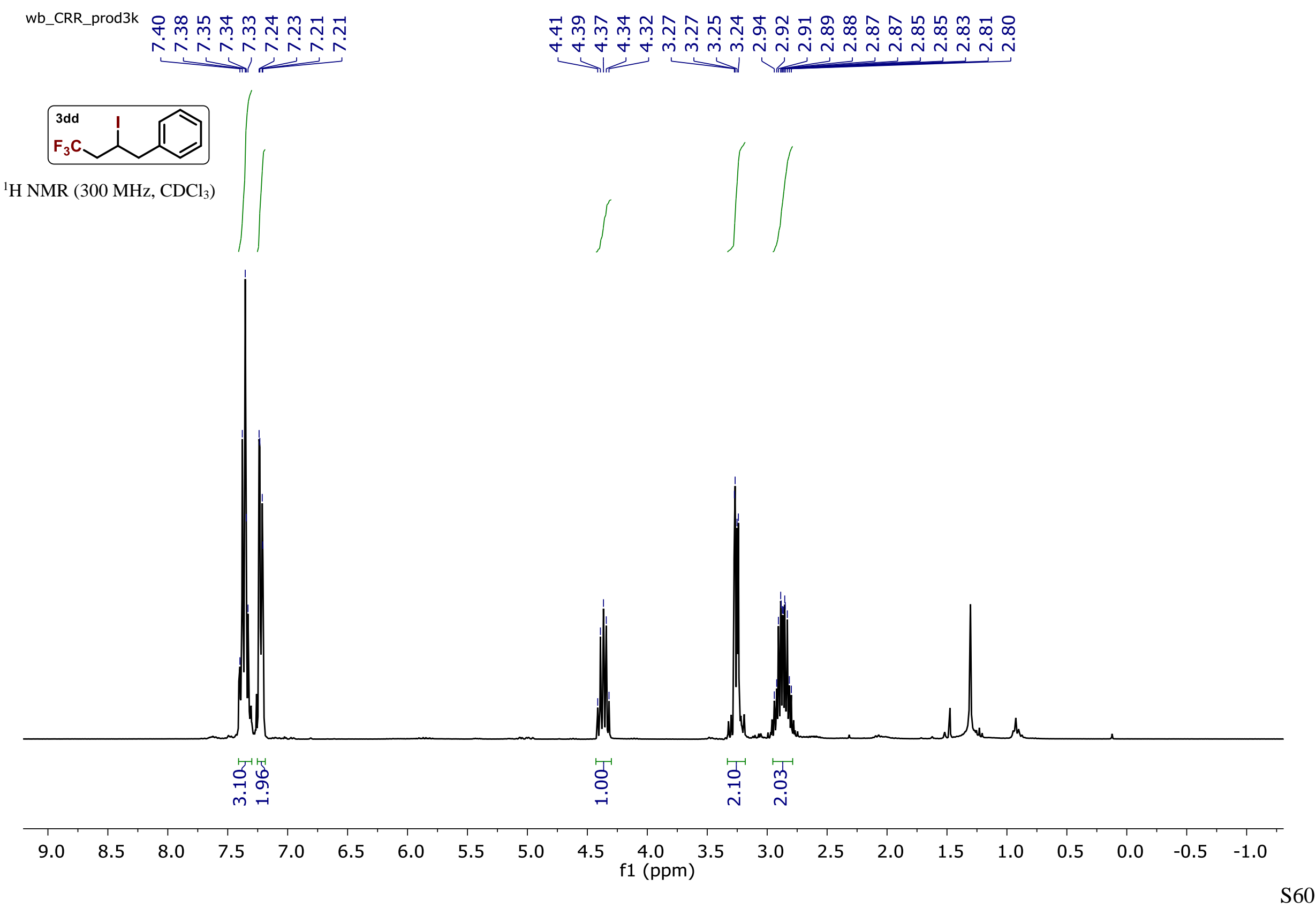


กำ 운

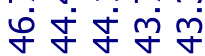

tैm m.

ํํํํำ

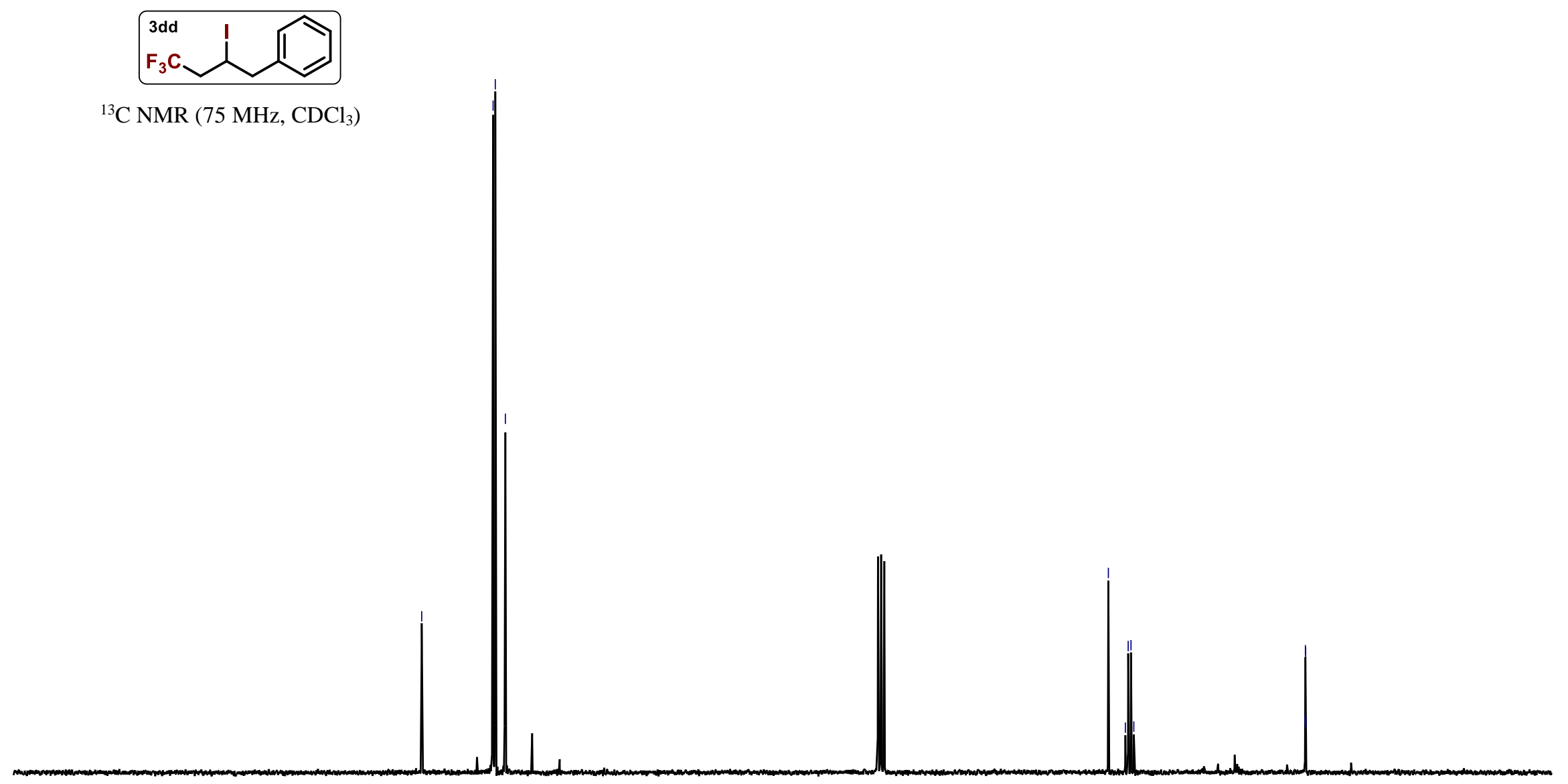




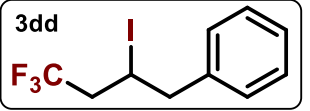

${ }^{19} \mathrm{~F} \mathrm{NMR} \mathrm{(282} \mathrm{MHz,} \mathrm{CDCl}_{3}$ )

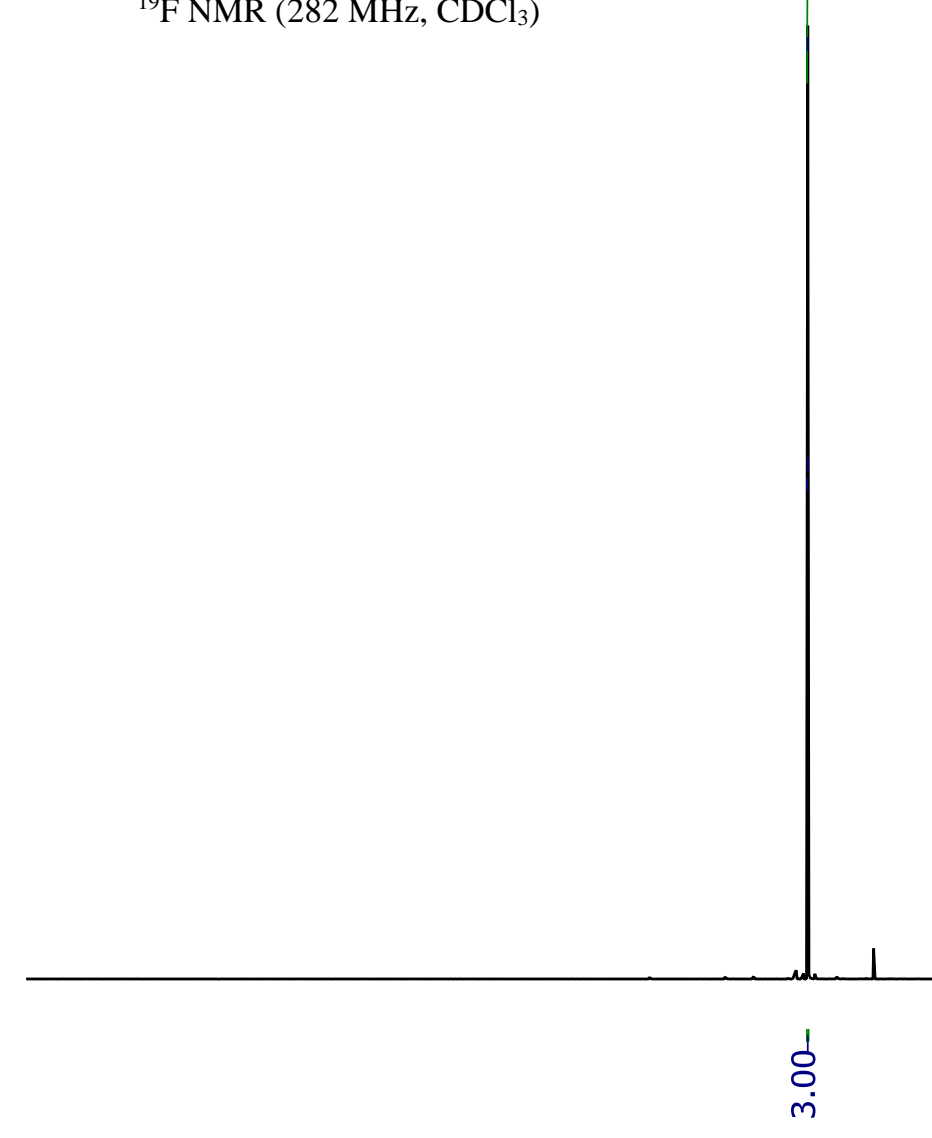

\begin{tabular}{lllllllllllllllllllll}
\hline 0 & -10 & -20 & -30 & -40 & -50 & -60 & -70 & -80 & -90 & -100 & -110 & -120 & -130 & -140 & -150 & -160 & -170 & -180 & -190 & -20(
\end{tabular}




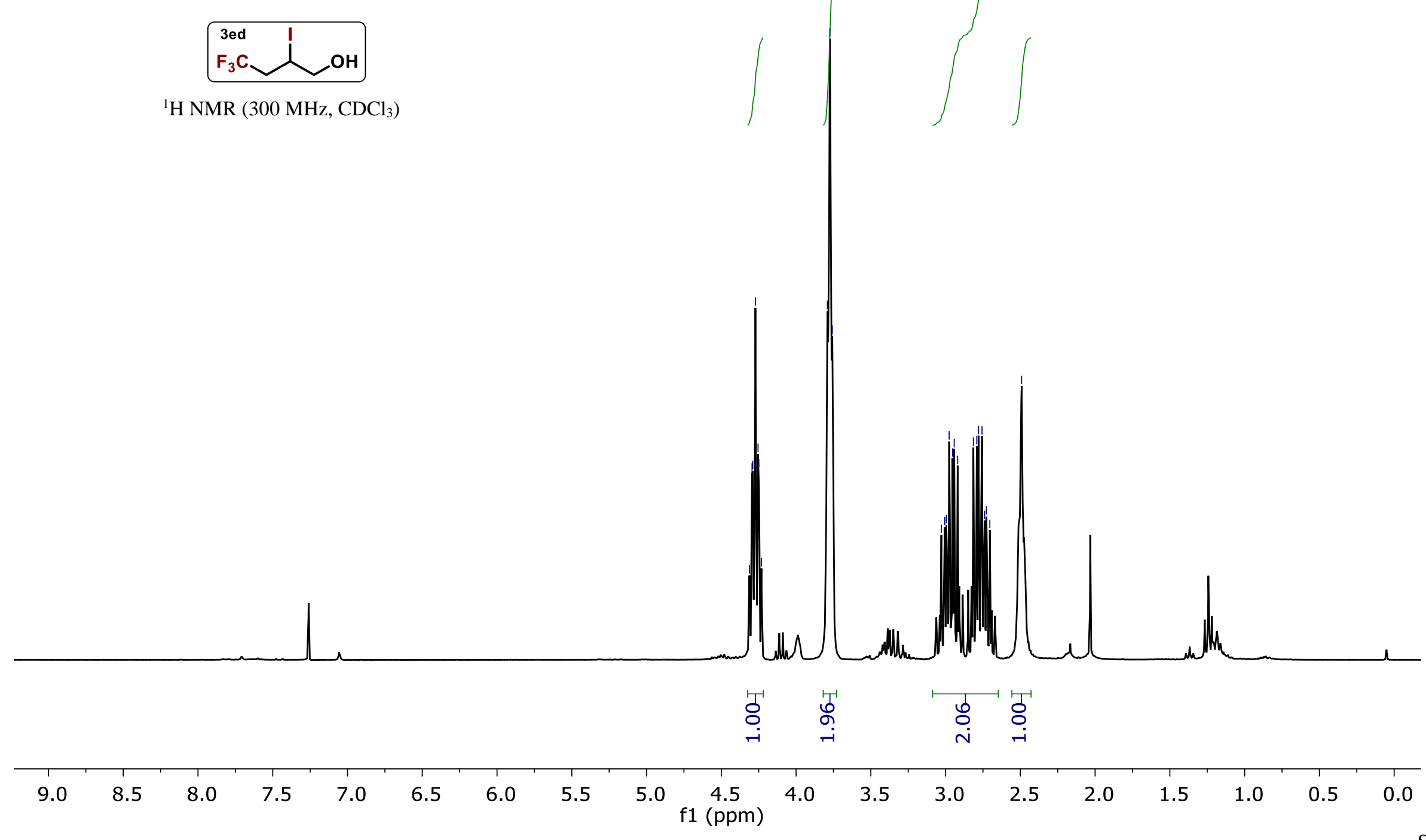

${ }^{1} \mathrm{H} \mathrm{NMR}\left(300 \mathrm{MHz}, \mathrm{CDCl}_{3}\right)$

- mm n N N N N N N N N 
wb_CRR_3kdef

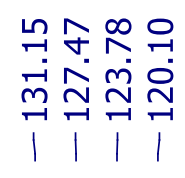

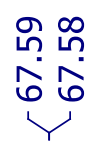

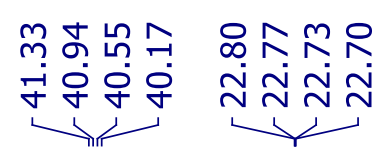<smiles>CCC(CO)CCCCC(F)(F)F</smiles>

${ }^{13} \mathrm{C}$ NMR $\left(75 \mathrm{MHz}, \mathrm{CDCl}_{3}\right)$

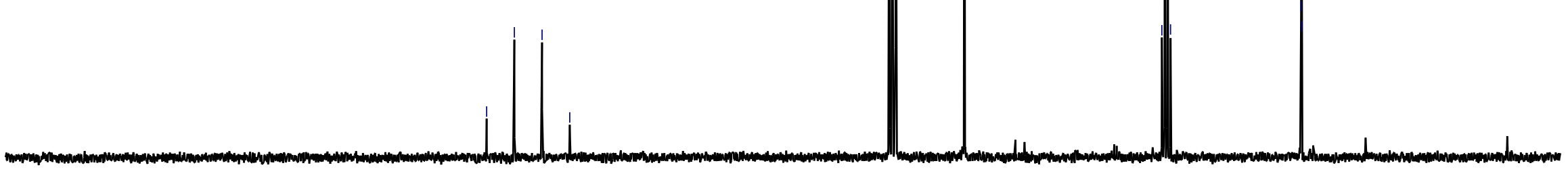

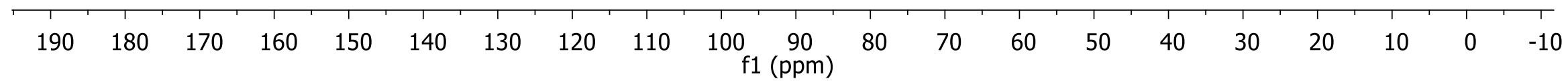

S64 


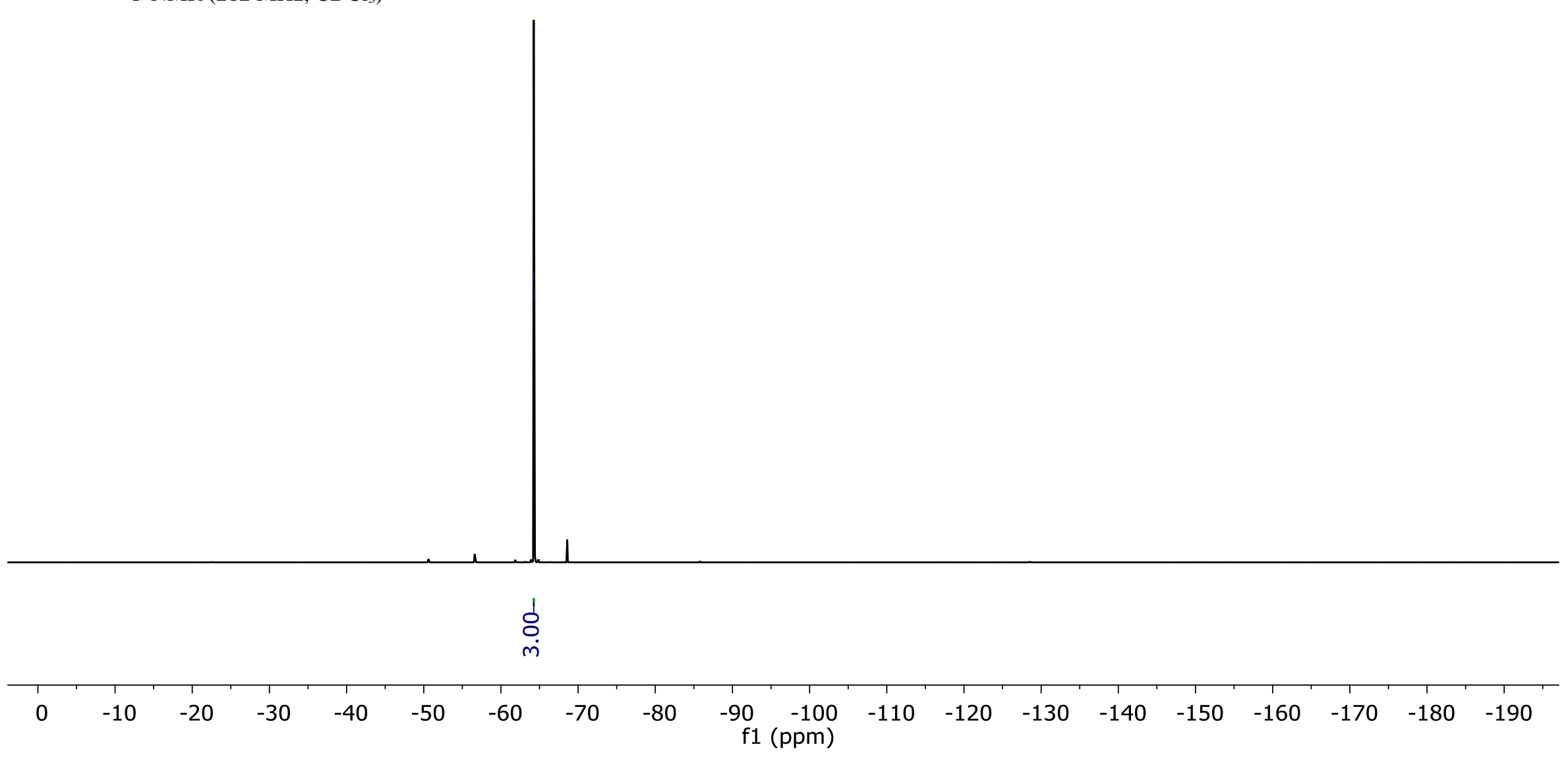




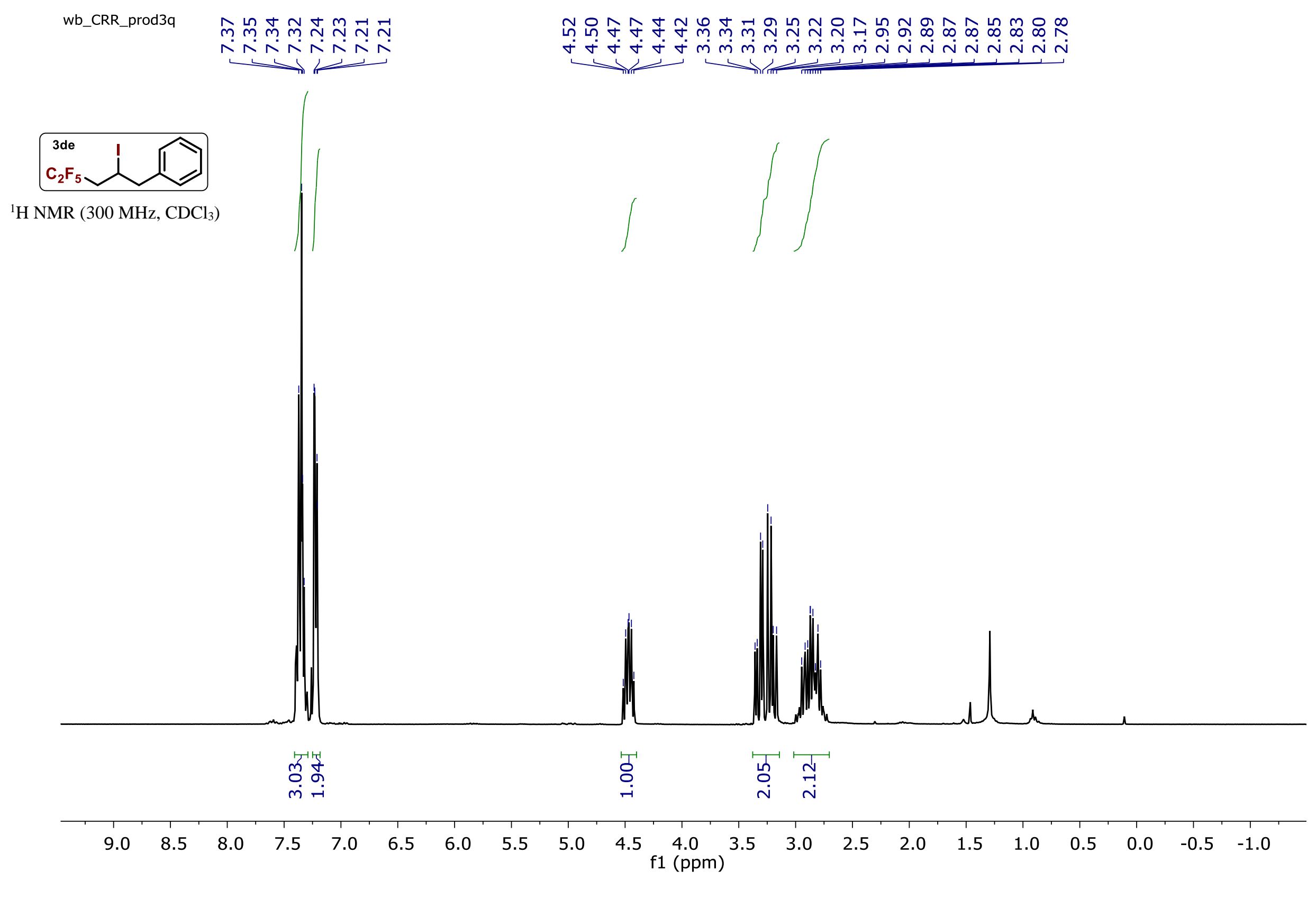




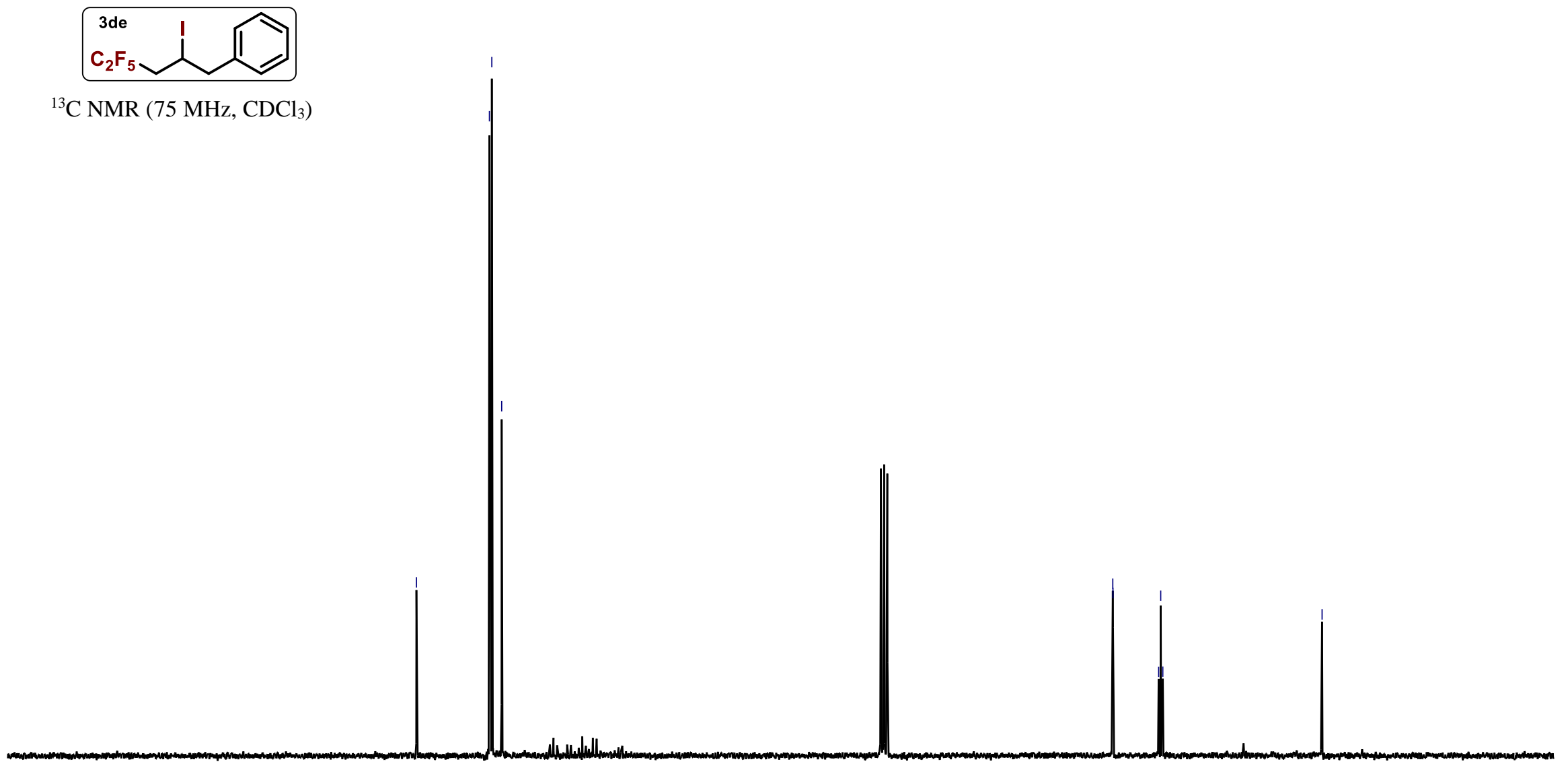




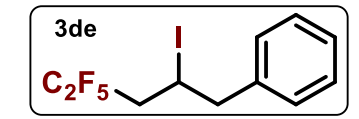

${ }^{19} \mathrm{~F}$ NMR $\left(282 \mathrm{MHz}, \mathrm{CDCl}_{3}\right)$

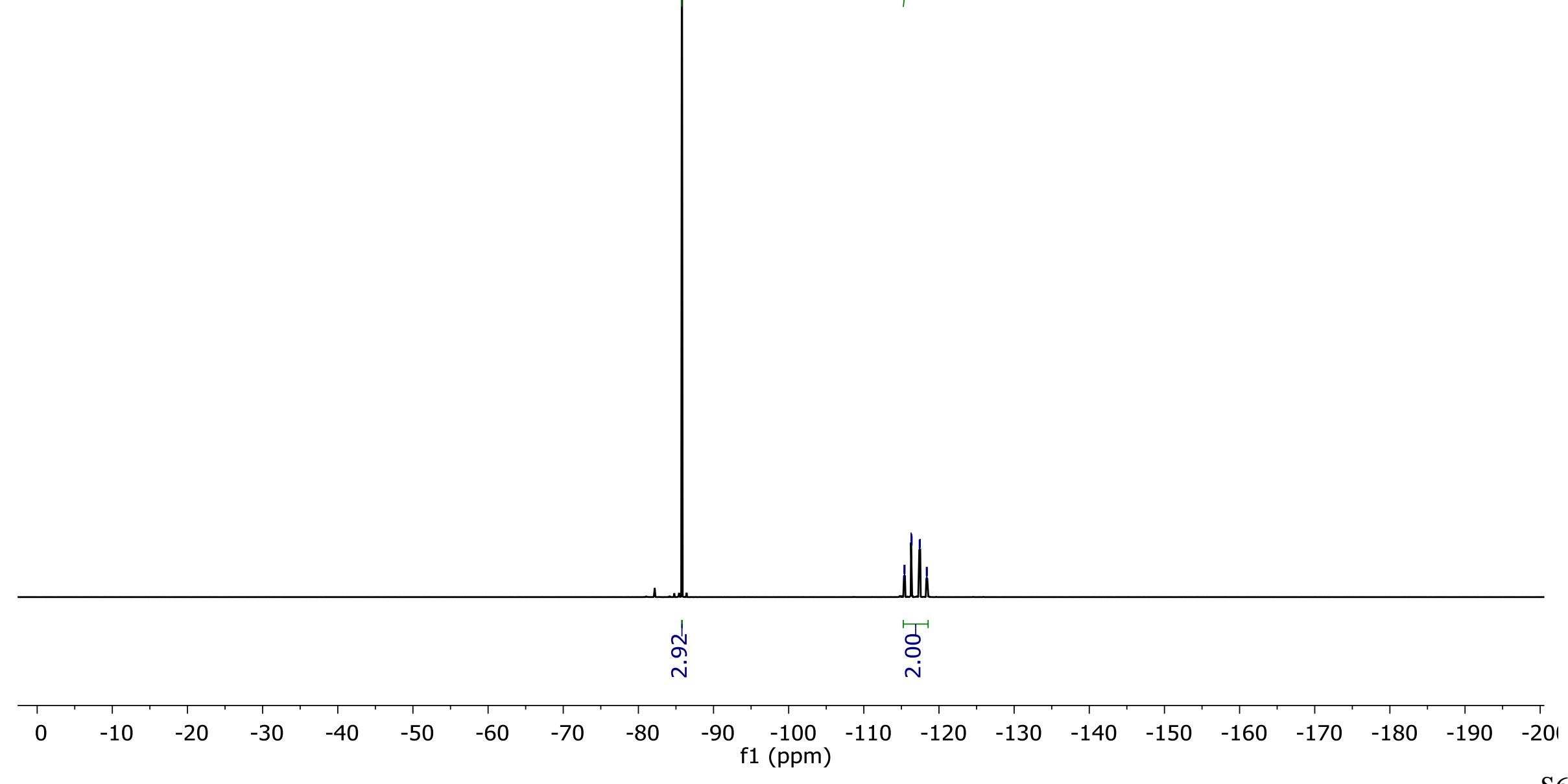




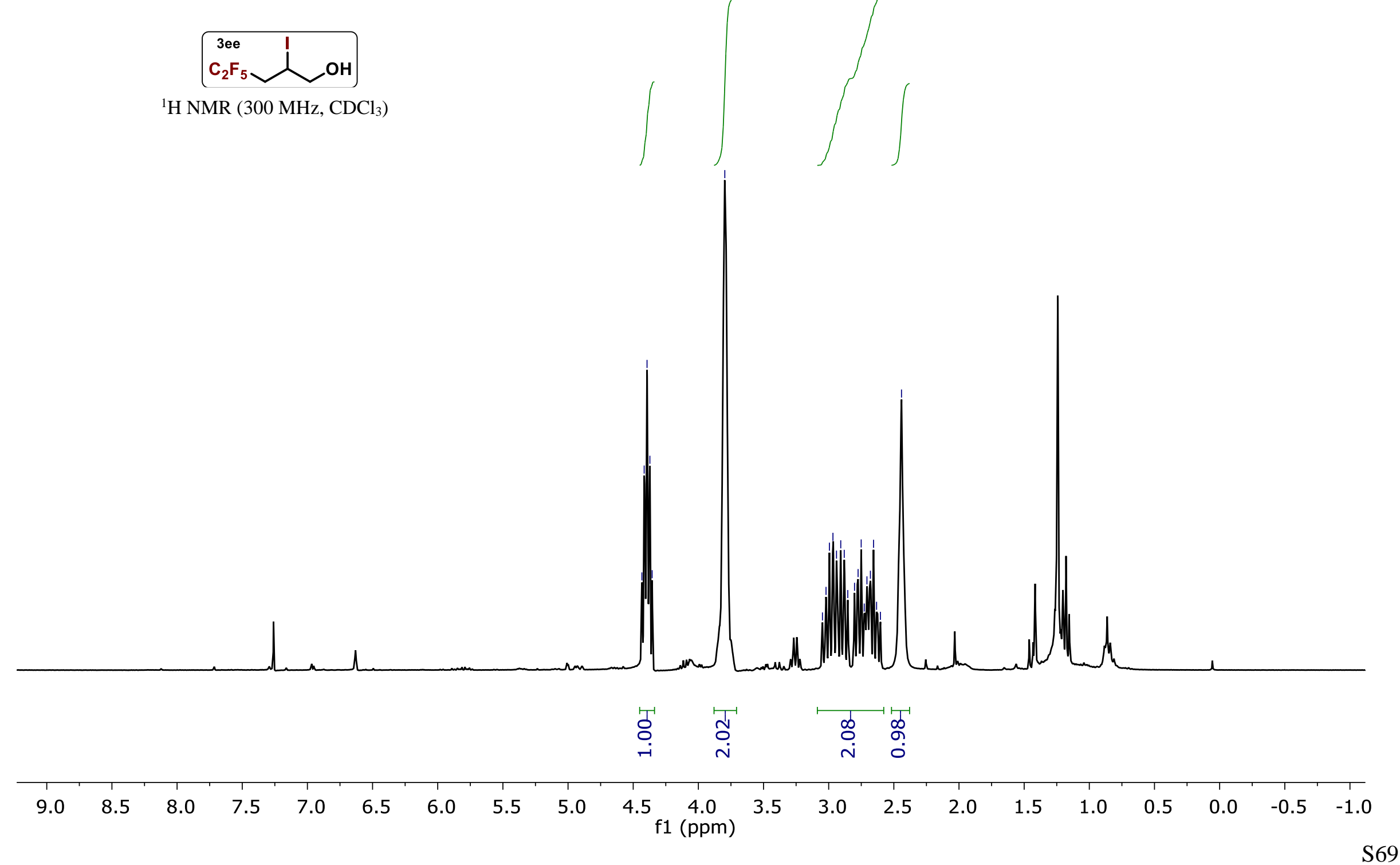

${ }^{1} \mathrm{H}$ NMR (300 MHz, $\mathrm{CDCl}_{3}$ )

年 
wb_CRR_prod3o

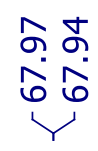

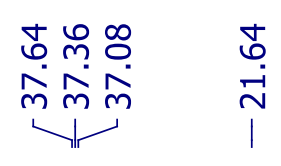

$\mathrm{C}_{2} \mathrm{~F}_{5} \longrightarrow \mathrm{OH}$

${ }^{13} \mathrm{C}$ NMR (75 MHz, $\mathrm{CDCl}_{3}$ )

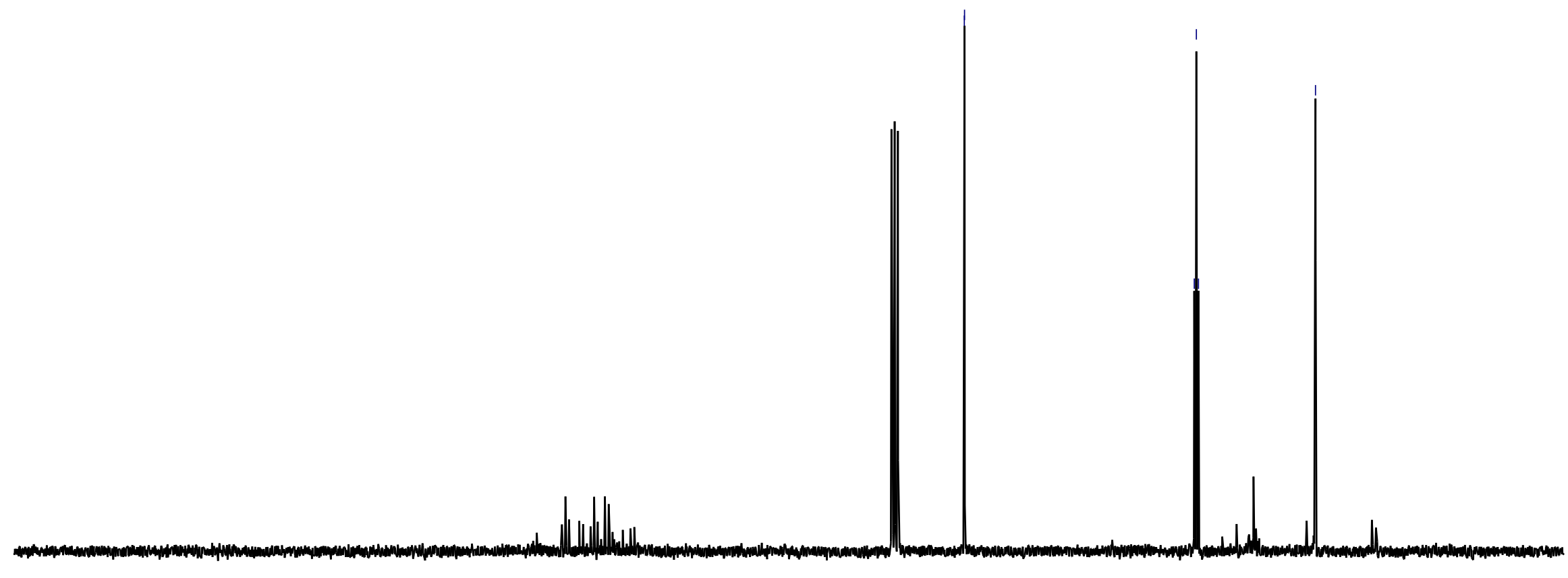

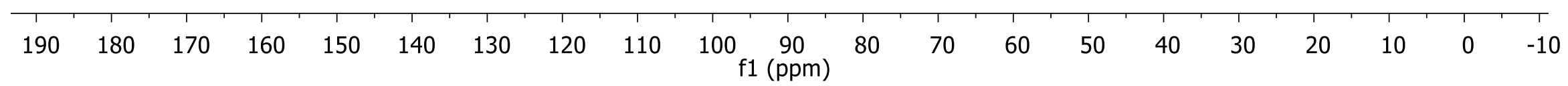

S70 
ه

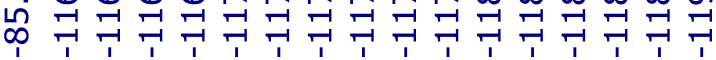

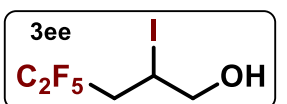

${ }^{19} \mathrm{~F}$ NMR $\left(282 \mathrm{MHz}, \mathrm{CDCl}_{3}\right)$

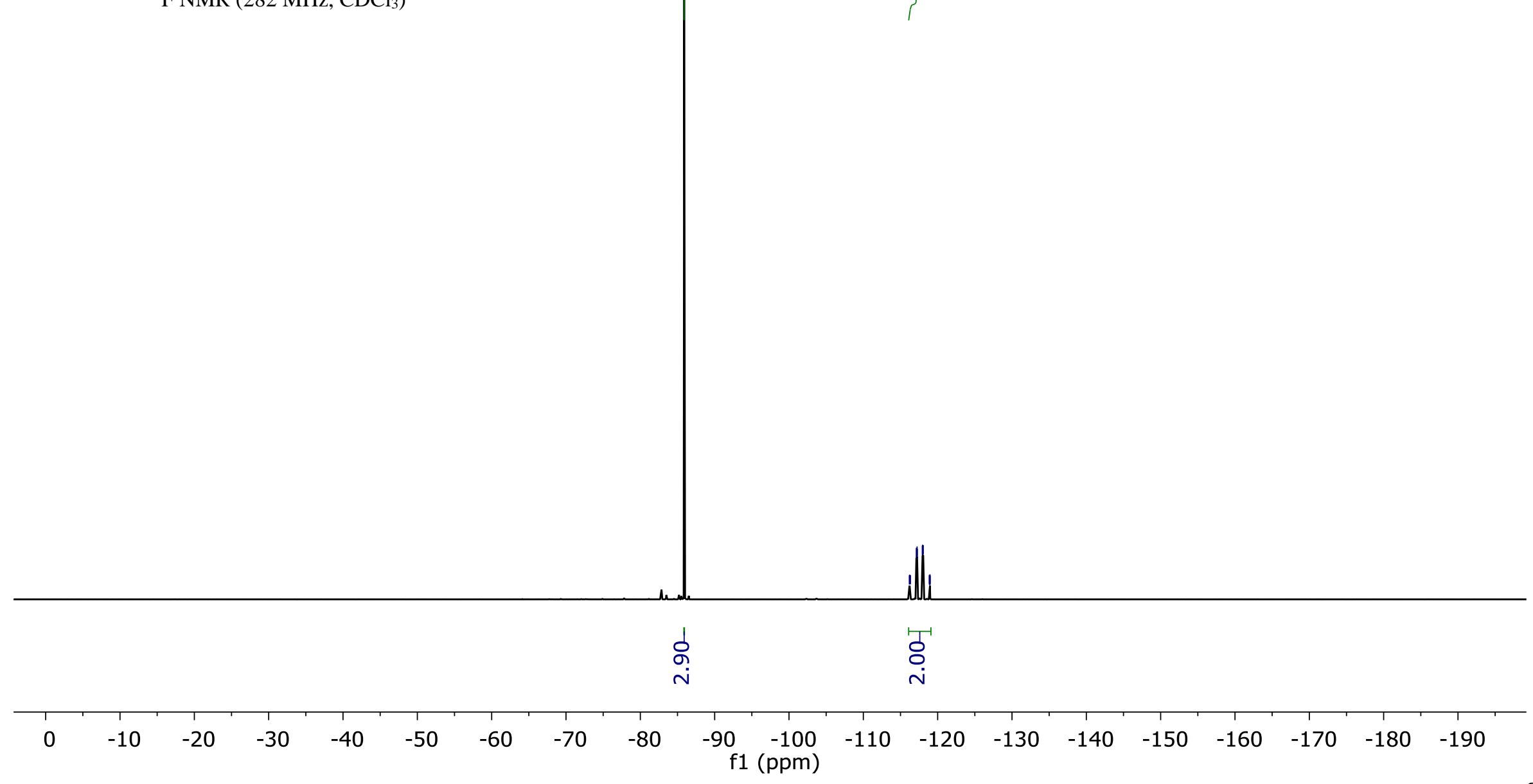




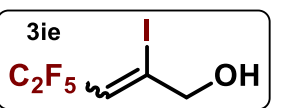

$\mathrm{H}$ NMR (300 MHz, $\mathrm{CDCl}_{3}$ )
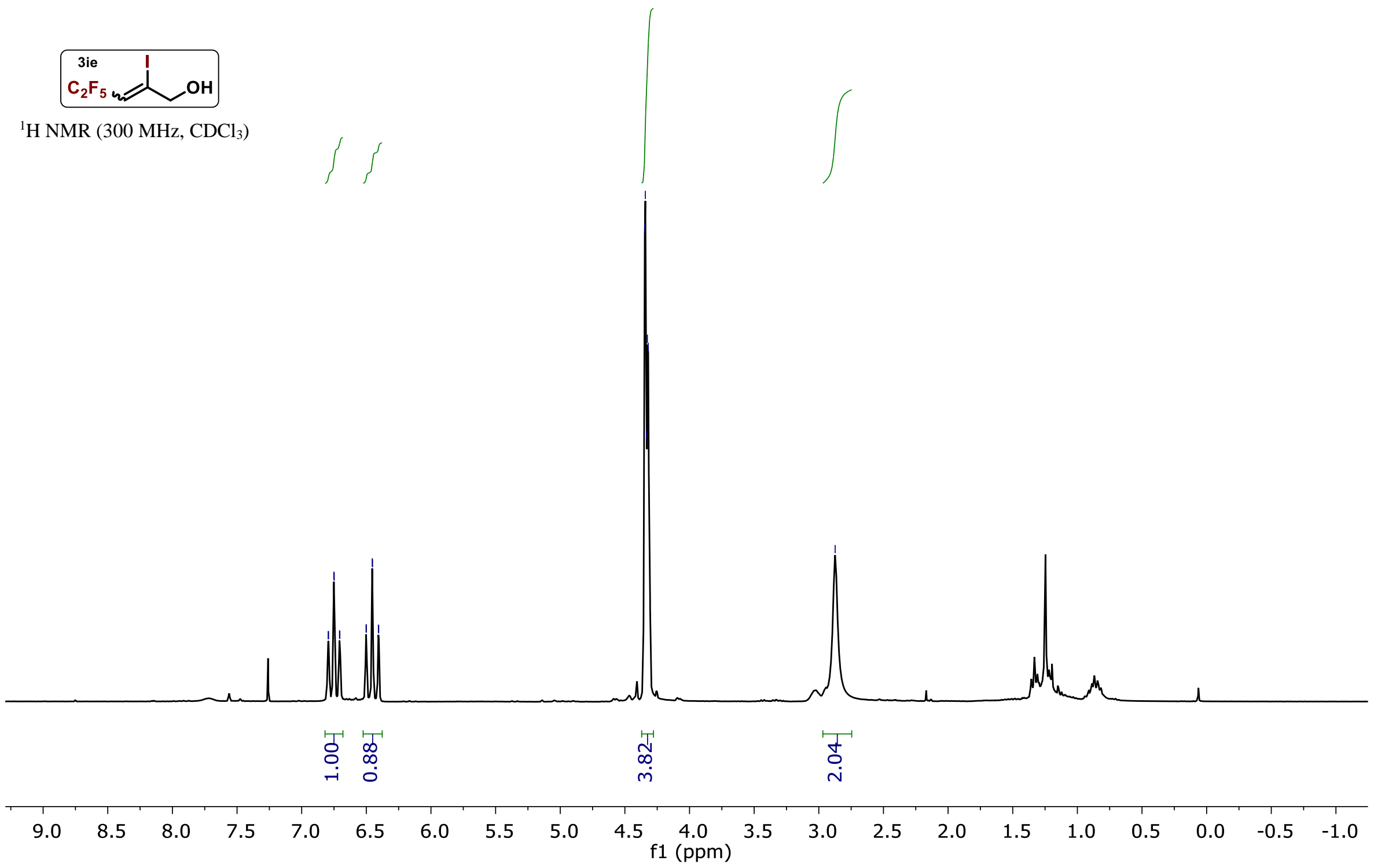


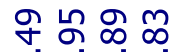

청

保

14

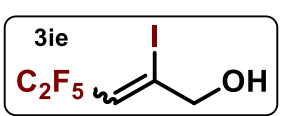

${ }^{13} \mathrm{C}$ NMR $\left(75 \mathrm{MHz}, \mathrm{CDCl}_{3}\right)$

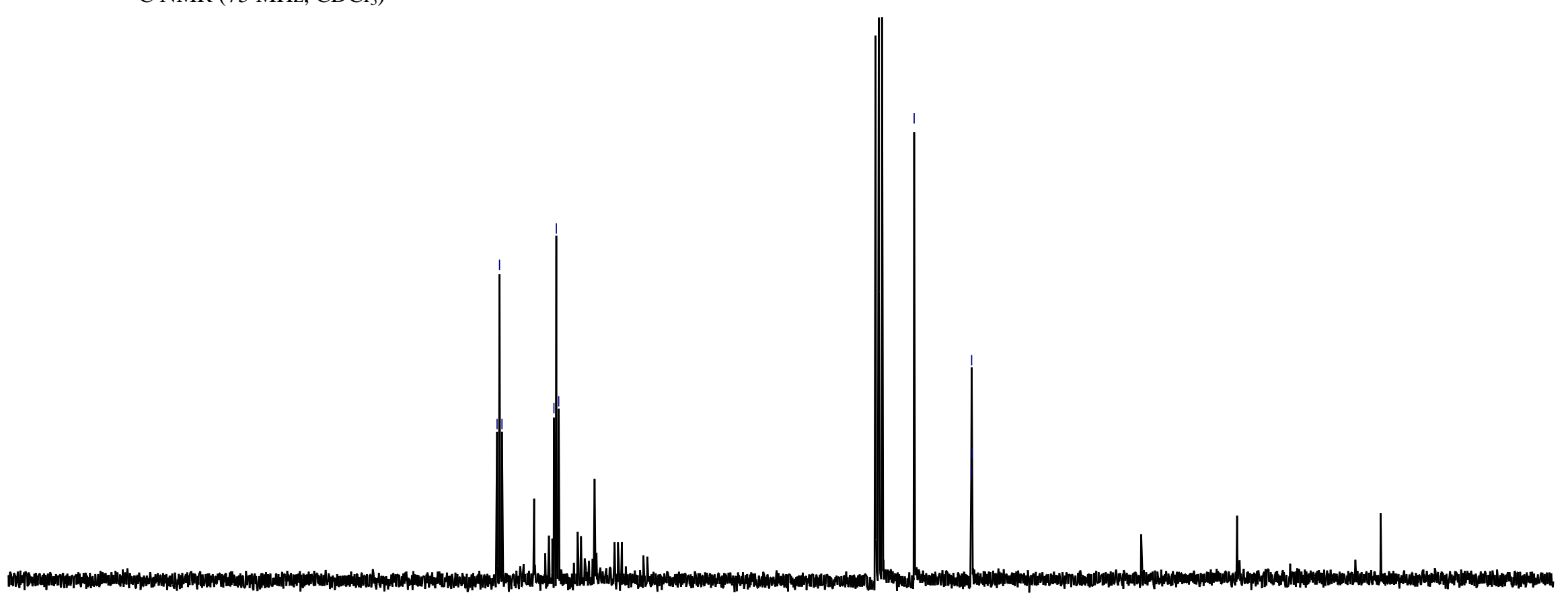

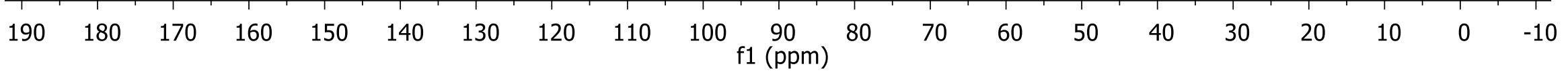




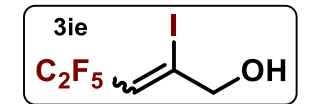

${ }^{19} \mathrm{~F}$ NMR $\left(282 \mathrm{MHz}, \mathrm{CDCl}_{3}\right)$
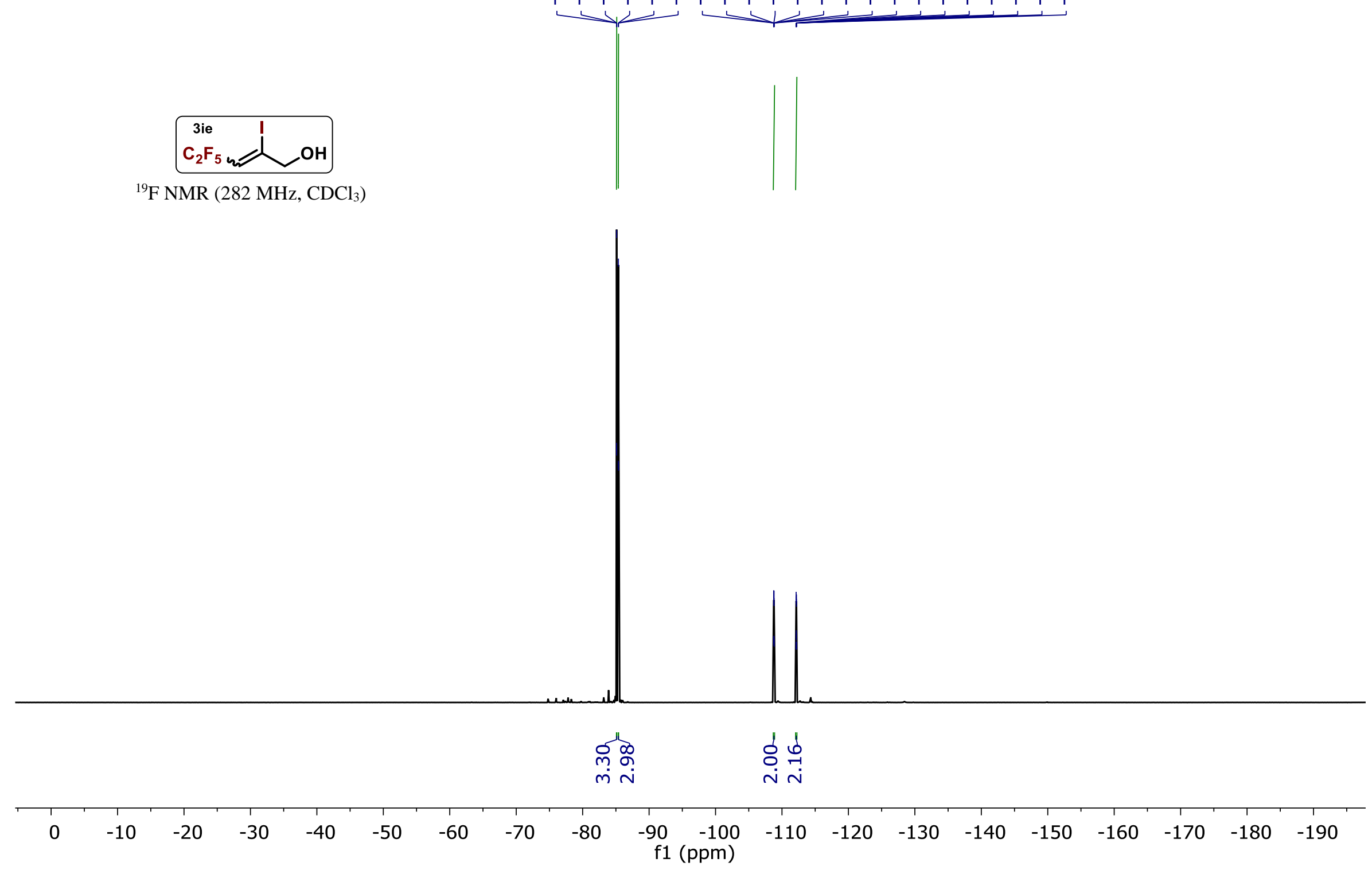
wb_CRR_160oriso m m

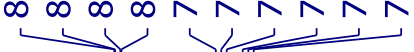

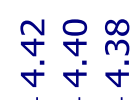

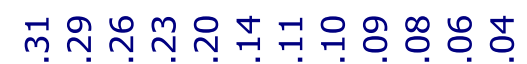

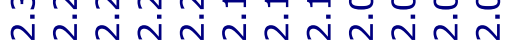
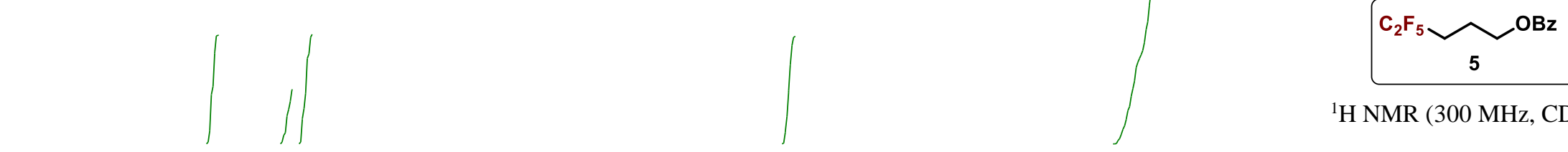

${ }^{1} \mathrm{H}$ NMR (300 MHz, $\left.\mathrm{CDCl}_{3}\right)$

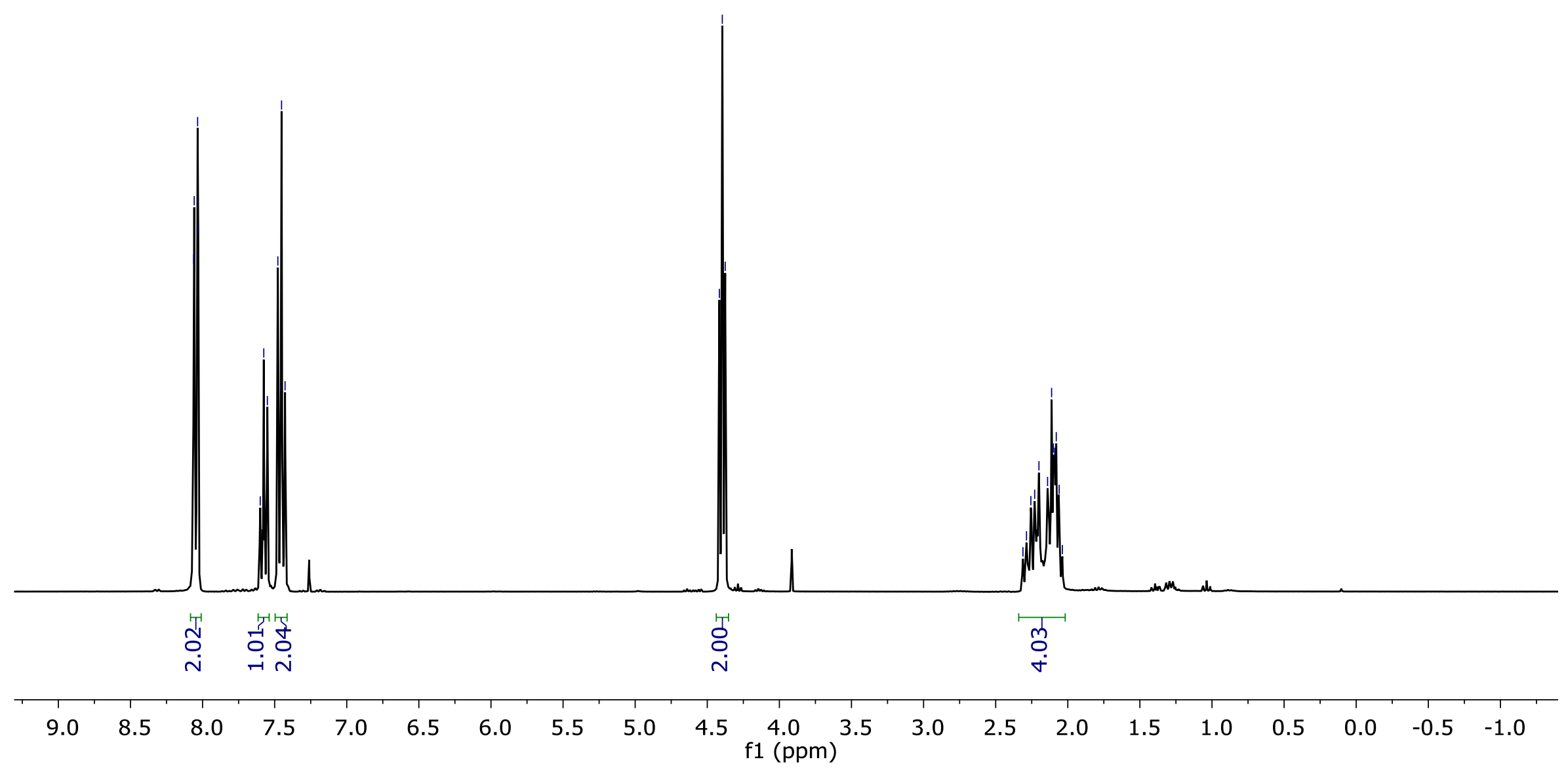




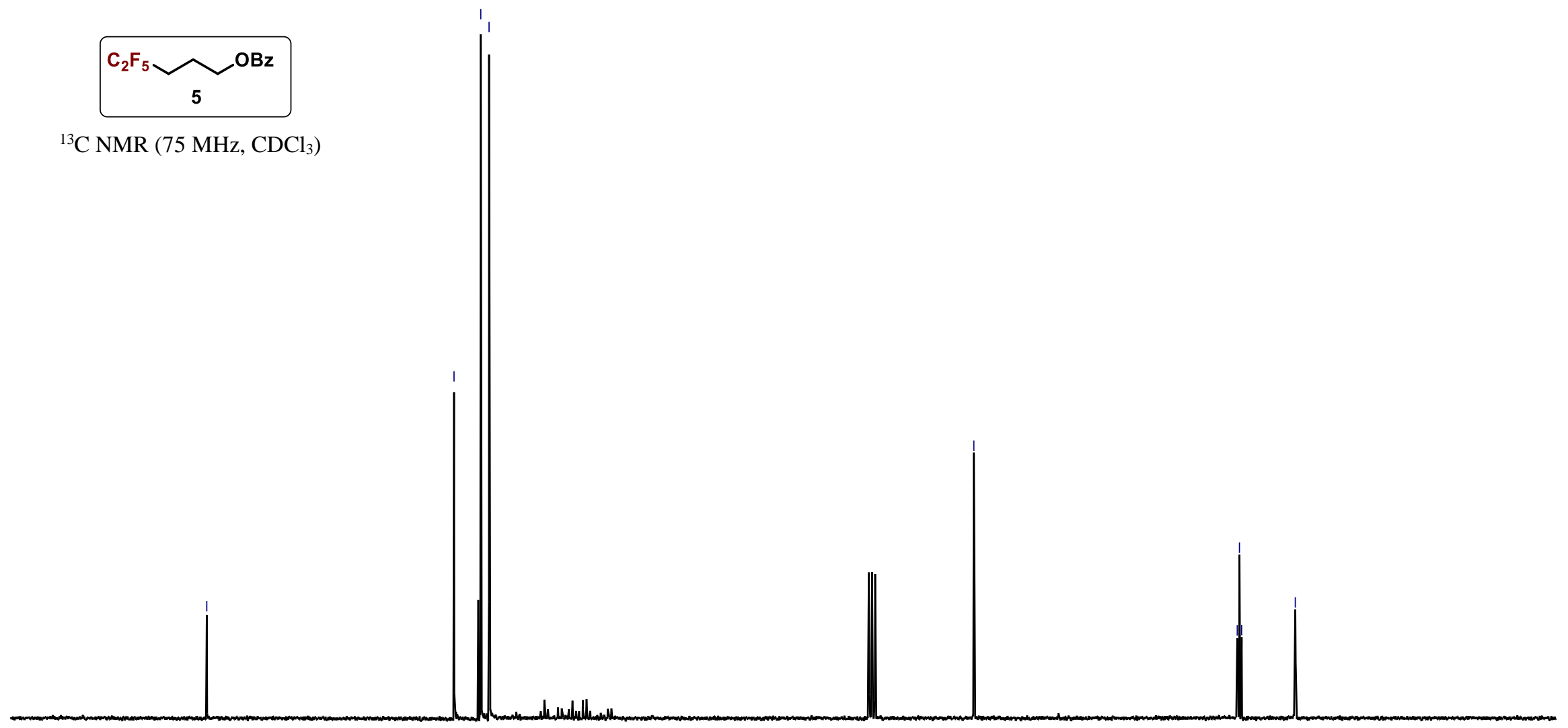

\begin{tabular}{|c|c|c|c|c|c|c|c|c|c|c|c|c|c|c|c|c|c|c|c|c|}
\hline 190 & 180 & 170 & 160 & 150 & 140 & 130 & 120 & 110 & 100 & $\begin{array}{c}90 \\
\mathrm{f} 1(\mathrm{ppm})\end{array}$ & 80 & 70 & 60 & 50 & 40 & 30 & 20 & 10 & 0 & -10 \\
\hline
\end{tabular}




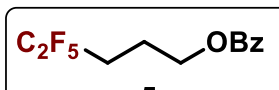

${ }^{9} \mathrm{~F}$ NMR (282 MHz, $\mathrm{CDCl}_{3}$ )
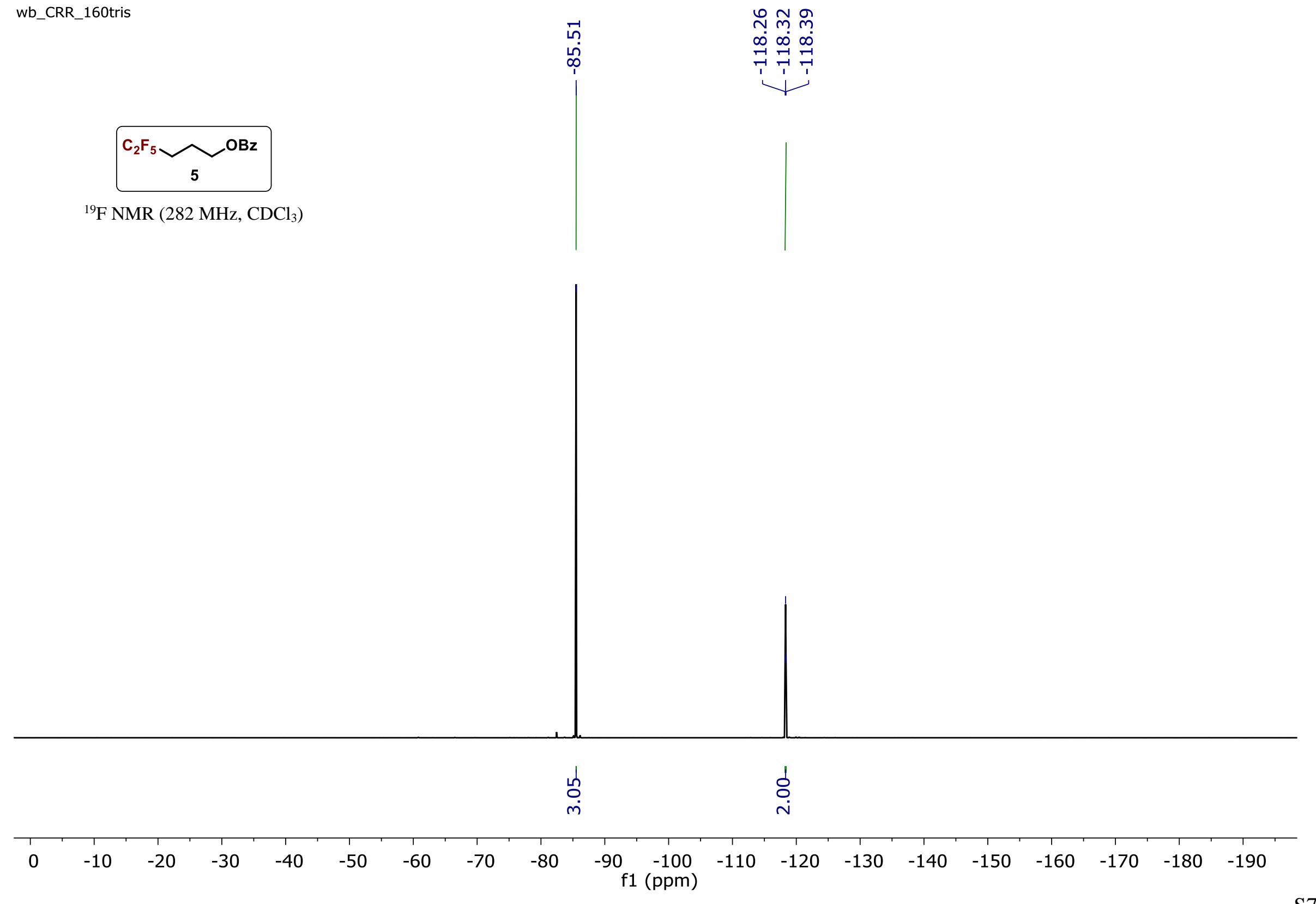